\title{
Efficacy of Filtration Processes to Obtain Water Clarity at K East Spent Nuclear Fuel Basin
}

\author{
J. B. Duncan \\ CH2M HILL Hanford Group, Inc. \\ Richland, WA 89352 \\ U.S. Department of Energy Contract DE-AC27-99RL14047
}

EDT/ECN: DRF

UC:

Cost Center: 7S110

Charge Code:

B\&R Code:

Total Pages: 85

Key Words: K East Basin, water, clarity, filtration, coagulation, PALI Keystone, filter, sludge, debris, hydrolasing, contamination, scouting ERDF, PSD, light attenuation, vacuum, radiation, samples, evaluation

Abstract: The objective is to provide water clarity to the $\mathrm{K}$ East Basin via filtration processes. Several activities are planned that will challenge not only the capacity of the existing ion exchange modules to perform as needed but also the current filtration system to maintain water clarity. Among the planned activities are containerization of sludge, removal of debris, and hydrolasing the basin walls to remove contamination.

TRADEMARK DISCLAIMER. Reference herein to any specific commercial product, process, ar service by trade name, trademark, manufacturer, or ofherwise, does not necessarily constitute or imply tts endorsement, recommendation, or fevoring by the United States Government or any agency thereof or tit contractors or subcontractors.

Printed in the United States of America. To abtain copies of this document, contact: Document Contral Services, P.O. Box 960, Mailstop H6-08, Richland WA 99352, Phone (509) 372-2420; Fax (509) 376-4989.

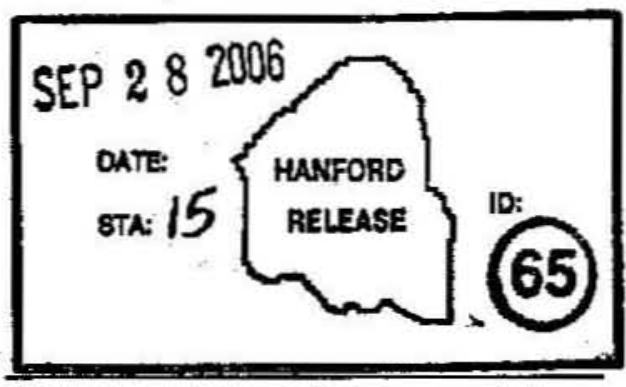

Release Stamp 


\section{EFFICACY OF FILTRATION PROCESSES TO OBTAIN WATER CLARITY AT K EAST SPENT NUCLEAR FUEL BASIN}

\section{J. B. Duncan}

CH2M HILL Hanford Group, Inc.

Date Published

September 2006

\section{CH2INHILL \\ Hanford Group, Inc.}

Prepared for the U.S. Department of Energy

Office of River Protection

Contract No. DE-AC27-99RL14047

Approved for public release; distribution is unlimited 
RPP-RPT-30093, Rev. 0

\section{Table of Contents}

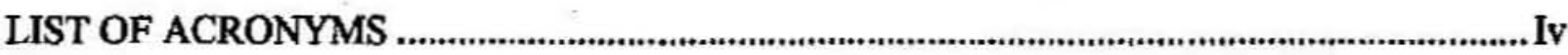

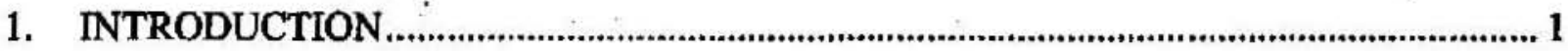

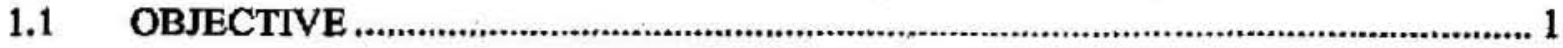

1.2 K EAST BASIN HISTORY EMPLOYING FILTRATION ........................................... 1

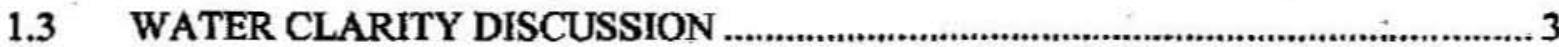

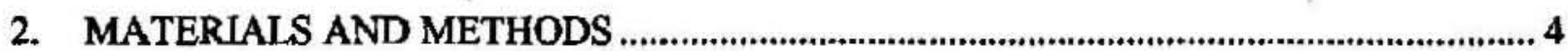

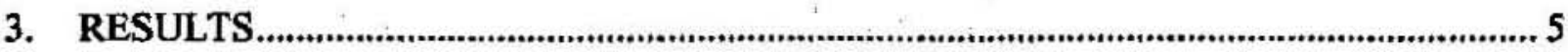

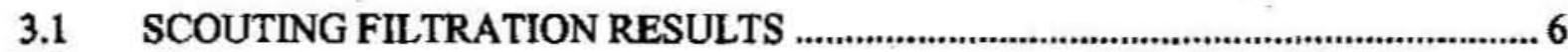

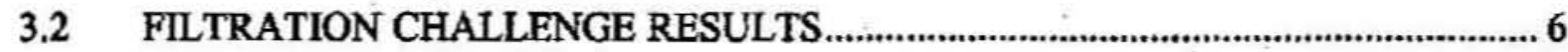

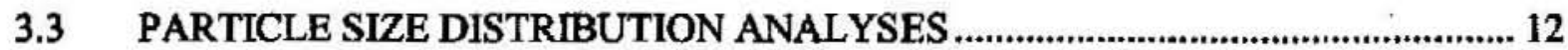

3.4 FURTHER FILTRATION TESTING (10-MICRON GLASS FIBER) ...................... 15

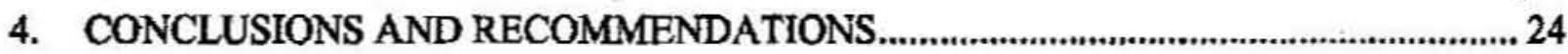

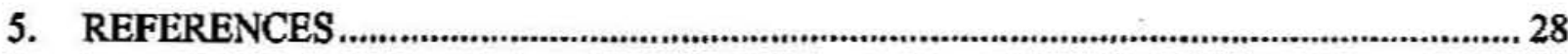

APPENDIX A ANALYSES OF KE BASIN COMPOSITE ................................................... A-1

APPENDIX B INITIAL TEST OF 40-MICRON PALL AND 5-MICRON KEYSTONE

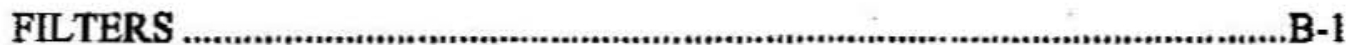

APPENDIX C SCOUTING TESTS: CANDIDATE FILTER MEDIA CHALLENGED

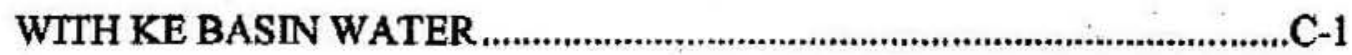

APPENDIX D LONG RUN TEST: ANALYSES OF 40-MICRON FILTER

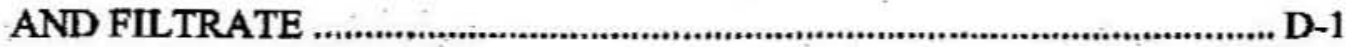

APPENDIX E LONG RUN TEST: ANALYSES OF 5-MICRON FILTER

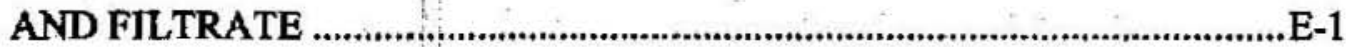

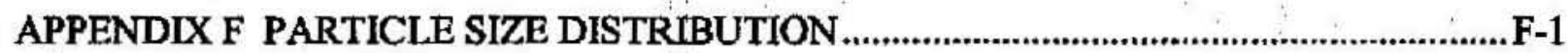

APPENDIX G PARTICLE SIZE DISTRIBUTION FOR KEYSTONE AND

PALL 10-MICRON GLASS FIBER FILTERS .............................................. G-1 


\section{LIST OF FIGURES}

Figure 1. Schematic of the Scattering of Light by a Suspended Particle via the Processes of Reflection, Refraction, and Diffraction.

Figure 2. Attenuation Cross-section (Attenuation Per Unit Mass) of a Suspension of Spherical Particles as a Function of Their Diameter.

Figure 3. Composite Suspended Solids versus NTU Values.................................................... 7

Figure 4. Effluent Turbidity Using KE Basin Challenge (NTU Values)........................................ 8

Figure 5. Composite Turbidity Retained by the Filter.................................................................... 8

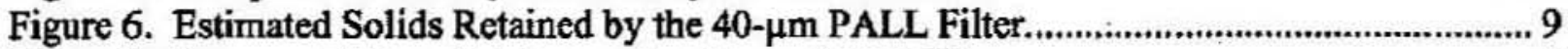

Figure 7. Pressure Differential Across the 40- $\mu$ m PALL Filter. .................................................... 9

Figure 8. Effluent Turbidity Using KE Basin Challenge................................................................. 11

Figure 9. Composite Turbidity Retained by the Filter..................................................................... 11

Figure 10. Estimated Solids Retained by the 5- $\mu \mathrm{m}$ Filter................................................................ 12

Figure 11. Pressure Differential Across the 5- $\mu \mathrm{m}$ Filter. ............................................................ 12

Figure 12. Volume-based Particle Size Distributions of KE-Basin Water Composite................. 14

Figure 13. Volume-based Particle Size Distributions of 40- $\mu \mathrm{m}$ Filtrat ..................................... 14

Figure 14. Effluent Turbidity From 10- $\mu \mathrm{m}$ Keystone Filter Using KE Basin Challenge ........... 15

Figure 15. Composite Turbidity Retained by 10- $\mu \mathrm{m}$ Keystone Filter........................................... 16

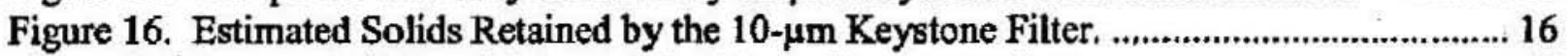

Figure 17. Pressure Differential Across the 10- $\mu \mathrm{m}$ Keystone Filter.............................................. 17

Figure 18. Effluent Turbidity From 10- $\mu \mathrm{m}$ PALL, Using KE Basin Challenge............................ 17

Figure 19. Composite Turbidity Retained by 20- $\mu \mathrm{m}$ PALL Filter................................................... 18

Figure 20. Estimated Solids Retained by the 10- $\mu \mathrm{m}$ PALL Filter................................................ 18

Figure 21. Pressure Differential Across the 10- $\mu$ m PALL Filter ................................................ 19

Figure 22. Volume-based Particle Size Distributions of KE-Basin Water Influent to

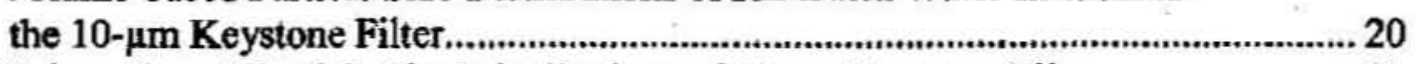

Figure 23. Volume-based Particle Size Distributions of 10 um Keystone Filtrate...................... 21

Figure 24. Volume-based Particle Size Distributions of KE-Basin Water Influent to the 10- $\mu \mathrm{m}$ PALL Filter. 21

\section{LIST OF TABLES}

Table 1. Initial and Average Turbidity Measured During Scouting Tests...................................... 6

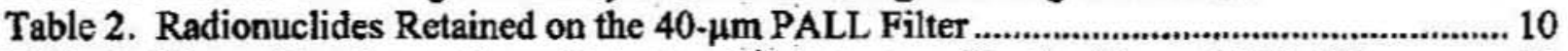

Table 3. Mass of Analytes Above Detection Limit Captured by the 40- $\mu \mathrm{m}$ PALL Filter ........... 10

Table 4. Mass of Analytes Above Detection Limit Captured by the 5- $\mu \mathrm{m}$ Filter. ....................... 13

Table 5. Radionuclides Retained on the 5- $\mu \mathrm{m}$ Keystone Filter..................................................... 13

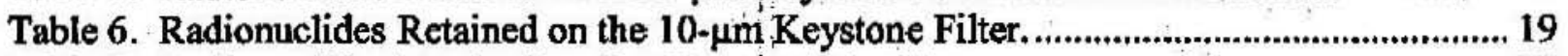

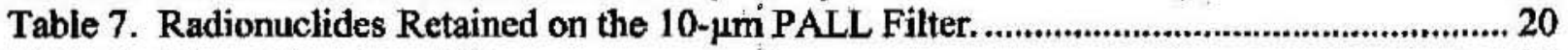

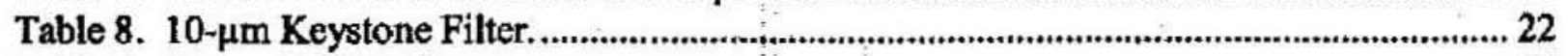

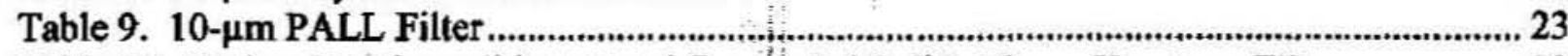

Table 10. Ratio of Radionuclide to Total Suspended Solids 10- $\mu \mathrm{m}$ Keystone Filter.................... 23

Table 11. Ratio of Radionuclide to Total Suspended Solids 10- $\mu \mathrm{m}$ PALL Filter ....................... 23

Table 12. Estimated Radionuclide Loading in $\mu \mathrm{Ci}$ on a Commercial Keystone $10-\mu \mathrm{m}$ Filter at Indicated Time. 


\section{RPP-RPT-30093, Rev. 0}

Table 13. Estimated Radionuclide Loading in $\mu \mathrm{Ci}$ on a Commercial PALL 10- $\mu \mathrm{m}$ Filter at Indicated Time

Table 14. Radionuclide Capture as a Fraction of Input. ............................................................ 25

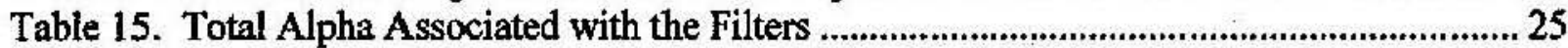

Table 16. Analytes Retained on the Filters......................................................................... 26

Table 17. Estimated Radionuclide Loading and Volume for a Filter Cartridge of 64 Square Feet. 


\section{RPP-RPT-30093, Rey. 0 \\ $\cdot$}

\section{LIST OF ACRONYMS}

$\begin{array}{ll}\text { ALARA } & \text { as low as reasonably achievable } \\ \text { DP } & \text { differential pressure } \\ \text { DQO } & \text { data quality objective } \\ \text { ERDF } & \text { Environmental Restoration Disposal Facility } \\ \text { GEA } & \text { gamma energy analysis } \\ \text { KE Basin } & \text { K East Basin } \\ \text { LDC } & \text { large diameter container } \\ \text { NLOP } & \text { North Load Out Pit } \\ \text { NTU } & \text { nephlometric turbidity units } \\ \text { PSD } & \text { particle size distribution } \\ \text { TRU } & \text { transuranic } \\ \text { TSS } & \text { total suspended solids } \\ \text { UCC } & \text { Underwater Construction Company }\end{array}$

(

.




\section{INTRODUCTION}

Several activities are planned for the $\mathrm{K}$ East Basin (KE Basin) that will challenge not only the capacity of the existing ion exchange modules to perform as needed but also the current filtration system to maintain water clarity. Among the planned activities are containerization of sludge, removal of debris, and hydrolasing the basin walls to remove contamination. Following the completion of hydrolasing activities, the basin will be de-watered and grout will be placed in the main basin and attached pits. These will be cut into sections forming monoliths that will be transported to the Environmental Restoration Disposal Facility (ERDF) for disposal.

Previous efforts for KE Basin clarity have demonstrated that coagulation is not a viable altemative for water clarity with polymeric flocculants (Letter CH2M-0501139, "Results of Coagulation Processes to Improve Water Clarity at the K East Spent Nuclear Fuel Basin"). The most plausible reason of the incapacity to coagulate suspended particles is that the measured zeta potential of the basin water is close to zero (HNF-SP-1201, Analysis of Sludge from Hanford K East Basin Canisters).

The KE Basin turbidity levels are at 4 nephlometric turbidity units (NTU) as measured against formazin calibration. During the course of the investigation, a sample of $\mathrm{KE}$ Basin water was subjected to a $0.45-\mu \mathrm{m}$ filter, the filtrate attained a turbidity of 0.05 NTU from an initial of 4.2 NTU (CH2M-0501139). It should also be pointed out that the $0.45-\mu \mathrm{m}$ filtrate gained exceptional clarity, as judged by the unaided eye.

\subsection{OBJECTIVE}

The objective of this effort is to provide clarity to the $\mathrm{K}$ East Basin via filtration processes. The client has determined that the effort does not constitute a treatability study under Washington Administrative Code (WAC) 173-303-040, "Dangerous Waste Regulations."

\subsection{K EAST BASIN HISTORY EMPLOYING FLTRATION}

KE Basin has had the following experience with filtration:

a. The recirculation loop had two cartridge filter housings. Each had a flow rate of $500 \mathrm{gpm}$. Each contained 88 spira-wound polypropylene cartridge filters. These typically were $5 \mu \mathrm{m}$. During the fuel segregation program (1984-1985), 10- $\mu \mathrm{m}$ filters were tried to extend time between change outs. These were not able to provide clarity so the project returned to using 5- $\mu \mathrm{m}$ filters. This system was abandoned in 1990 due to as low as reasonably achievable (ALARA) and waste management issues. In 1996, the cartridge filter housings were refurbished to hold seven cartridge filters that were sized so that one filter would fit inside a fuel canister (for interim storage). The project elected to use $1-\mu \mathrm{m}$ filters, which blinded shortly after being placed in service. The filter system was again abandoned at this time (interview with Steve Burke). 
b. During sludge sampling campaigns, a Rosedale $\mathrm{Ts}^{1}$ ( $5-\mu$ m pleated) filter was employed on the suction side of the pump. The Rosedale filters were 9.75 in. in length, pleated-sheet stainless-steel filter. The suction side versus the usual pressure side configuration was due to sampling data quality objectives (DQO) for particle size analysis, etc.; i.e., the sample was to be as undisturbed as possible. Once a surface cake was formed, the Rosedale performed successfully until the requisite differential pressure (DP) was achieved. However, at submicron particles the run time was considerably lessened (interview with Ron Baker).

c. More recently, KE Basin experienced a failure with filters in a large diameter container (LDC). Fifty-five 30-in. CUNO Corporation ${ }^{2} 5$ - $\mu$ m-rated polypropylene pleated-sheet BetaFine $^{3}$ XL filters were required as specified in LDC (H-1-87430, "Drawing KE-Basin STS LDC Filter Assembly"). The LDCs were to be used to retrieve basin floor and pit sludge for further treatment at T-Plant. The filters did not have an adequate run time and blinded quickly. Also, the filters were unable to be backwashed, cleared, and a run restarted. The LDCs were subsequently used to collect North Load Out Pit (NLOP) sludge using a fill and decant mode of operation. The NLOP sludge was pumped into the LDC and allowed to settle. The supernatant liquid was then decanted back into the NLOP.

d. The KE Basin has also tried a filter referred to as the "UCC filter." The Underwater Construction Company (UCC) provided the filters. In a document it was indicated that twelve banks of UCC filters consisting of four filters per bank have been used in the basin. The filters collected the maximum allowable particulates. It was reported that water clarity may have improved, and it was not clear that the continued use of these filters would be beneficial (KBCP-SRDP-05-MA-UNO6).

From the above information, there was no indication that filters of varying porosity (either nominal or absolute rated) were placed in front of the filters of choice for final configuration. With the exception of the Rosedale filter, very little if any laboratory confirmation of filtration media formulation efficacy to KE Basin needs has been carried out.

The one experience with depth filters occurred during the fuel segregation program. Since depth filters provide capacity to occlude larger particles at or very near the outer surface allowing smaller particles to enter and filter at depth, run times are usually longer than with sheet media challenged with the same particle size distribution (PSD).

The following discussion on water clarity is presented to elucidate the need to obtain filtration as a mechanism to achieve KE Basin water clarity.

\footnotetext{
${ }^{1}$ Rosedale ${ }^{\mathrm{TX}}$ is a trademark of Rosedale Products, Inc., Ann Arbor, Michigan.

${ }^{2} \mathrm{CUNO}$ is a registered trademark of CUNO Incorporated Corporation Meridian, Connecticut.

${ }^{3}$ BetaFine is a registered trademark of CUNO Incorporated Corporation Meridian, Comnecticut.
} 


\subsection{WATER CLARITY DISCUSSION}

Clarity of water is a function of light attenuation, i.e., the greater the attenuation of light, the lower the water clarity. There are several light-attenuating constituents of water but typically suspended particles are the dominant influence. The cloudiness encountered in certain bodies of water results from intense scattering of light by fine particles, a phenomenon commonly referred to as 'turbidity' ["Effects of Suspensiods (Turbidity) on Penetration of Solar Radiation in Aquatic Ecosystems," Kirk 1985]. Turbidity is not the same as clarity; these are distinct although inversely related optical concepts ("Turbidity, Suspended Sediment, and Water Clarity: A Review," Davies-Colley and Smith 2001).

According to Light Scattering by Small Particles (van de Hulst 1957), geometrical optics show that particles much larger than the wavelength of light $(0.4$ to $0.7 \mathrm{~nm})$ attenuate twice the light impinging on their cross-sectional area. This phenomenon is known as the "extinction paradox." Figure 1 is a schematic indicating light in a collimated beam impinging on a particle is all removed from the beam ("attenuated") by scattering due to the processes of refraction and reflection or else is absorbed by pigments associated with the particle. An equal amount of light is diffracted around the particle giving a total optical cross-section exactly twice the geometrical cross-section.

Figare 1. Schematic of the Scattering of Light by a Suspended Particle via the Processes of Reflection, Refraction, and Diffraction. (Colour and Clarity of Natural Waters, Davis-Colley 1993)

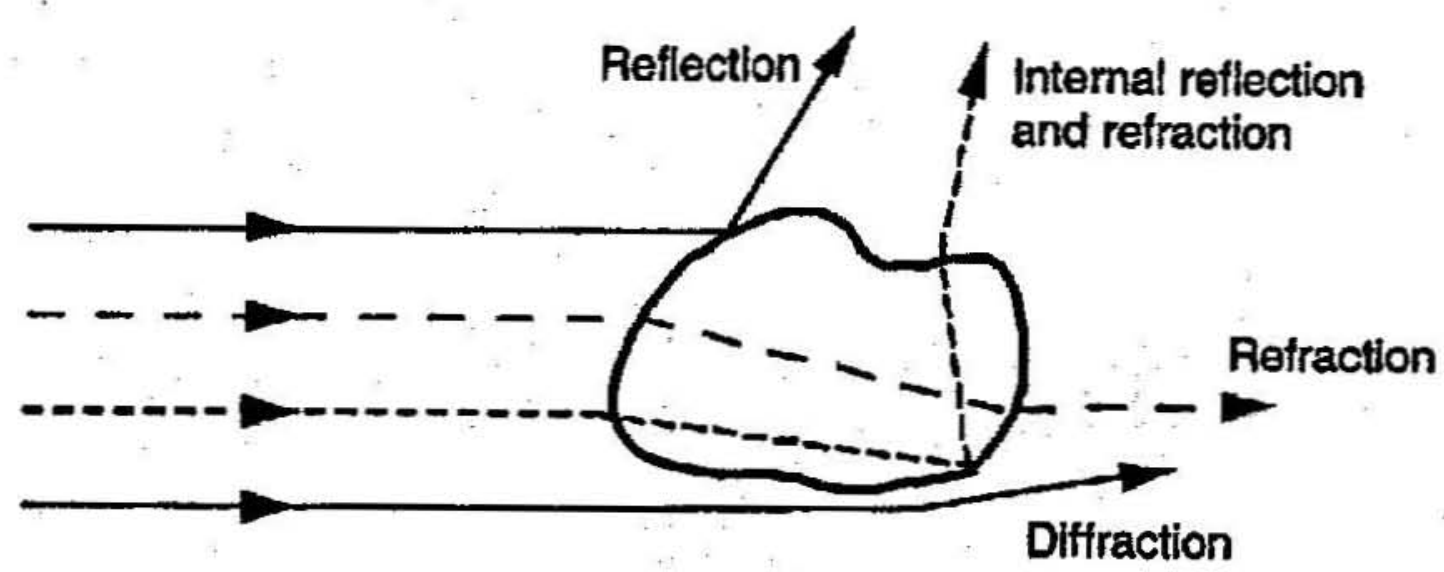

Light attenuation by a single particle depends most strongly on its size and therefore its projected cross-sectional area. Light attenuation by a suspension of particles depends mainly on the concentration of particles, expressed not as suspended sediment concentration but as geometrical cross-section (projected area) per unit volume [this quantity has the same units as light attenuation $\left.\left(\mathrm{m}^{2} / \mathrm{m}^{3}=\mathrm{m}^{-1}\right)\right]$. Therefore, light attenuation by suspended matter depends strongly on the distribution of particle sizes as it controls geometrical cross-section. Figure 2 shows the attenuation per unit mass concentration [=attenuation 'cross-section,' $\mathrm{m}^{-1} /\left(\mathrm{g} \mathrm{m}^{-3}\right)=\mathrm{m}^{2} / \mathrm{g}$ ] of suspended spherical particles as a function of their diameter. For "optically large" particles, the 
attenuation cross-section varies as the inverse of their diameter and declines as particle size increases. For "optically small" particles (much smaller than the wavelength of light), attenuation cross-section falls off rapidly with declining size. The most "optically efficient" particles are the particles in an intermediate size range; for quartz composition particles the attenuation cross-section peaks at $1.2 \mu \mathrm{m}$, and this peak position is not markedly different for other common minerals. Organic materials have much lower density as well as much lower refractive index relative to water, with the result that their attenuation cross-section peaks at larger sizes $(\sim 5 \mu \mathrm{m})$.

Figure 2. Attenuation Cross-section (Attenation Per Unit Mass) of a Suspension of Spherical Particles as a Function of Their Diameter.

(Davies-Colley 1993).

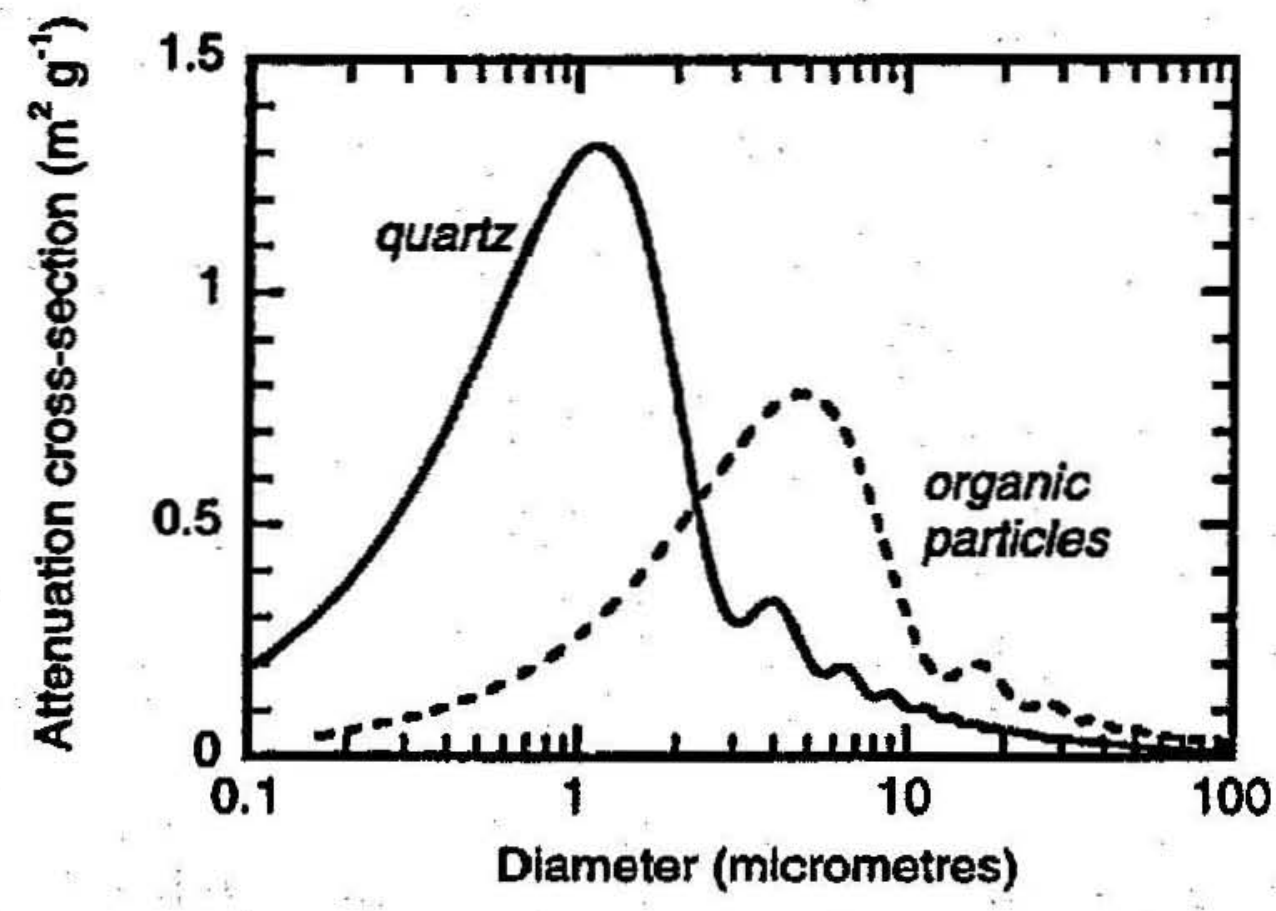

The scattering of light by highly aspherical (plate-shaped) crystals of clay mineral is appreciably higher than that of spheres of equal volume, particularly at backscattering angles ("Light Scattering from Particles of Different Shapes," Gibbs 1978).

Particles in the size range of 0.2 to $5 \mu \mathrm{m}$ for inorganics and a little larger (1 to $20 \mu \mathrm{m}$ ) for organic particles dominate light attenuation (Davis-Colley 1993; "Optical Water Quality - What Does It Mean and How Should We Measure It?" Kirk 1988). 
RPP-RPT-30093, Rev. 0

\section{MATERIALS AND METHODS}

To achieve water clarity, different candidate filter media were chosen varying in both media and particle size cutoff, and a laboratory effort was carried out under RPP-PLAN-26932, Test Plan to Demonstrate Efficacy of Filtration Processes to Obtain Water Clarity at KE Basin. The candidate filters were subject to a scouting test to determine filtration efficacy against KE Basin water. The scouting tests employed vacuum filtration with the criteria of success based on water clarity as a function of NTU measurements using a $\mathrm{HACH}^{4} 2100 \mathrm{AN}$ Turbidimeter.

The original list of candidate filters before scouting tests was the following:

a. PALL ${ }^{\mathrm{TM}^{5}}, 40 \mu \mathrm{m}$

b. Keystone Filter ${ }^{6}$
1. $20 \mu \mathrm{m}$
2. $10 \mu \mathrm{m}$
3. $5 \mu \mathrm{m}$
4. $1 \mu \mathrm{m}$
5. $0.3 \mu \mathrm{m}$

Scouting test results are presented in Section 3. Based on water clarity (NTU values) the candidates selected were the 40- $\mu \mathrm{m}$ PALL and 5- $\mu \mathrm{m}$ Keystone Filter filters. Another sample of KE Basin water was obtained and delivered to the laboratory for challenging the candidate filters. A test bed was constructed that allowed the candidate filters to be subject to an adjusted flow rate equivalent to the manufacturers' recommended flow rate per unit area. The test bed consisted of a peristaltic pump, an Omega ${ }^{7}$ rotameter for flow control, a gauge to indicate pressure differential across the filter, a 47-mm filter holder, and associated laboratory polypropylene tubing.

Forty liters of KE Basin water was received as a challenge to the candidate filters. A composite was made from the $40 \mathrm{~L}$ by using $1 \mathrm{~L}$ from each thoroughly mixed $10-\mathrm{L}$ carboy. From this composite, a standard curve relating NTU values to total suspended solids was obtained at varying dilutions of KE Basin water. The composite also was submitted for inductively coupled plasma spectroscopy analyses to determine cations, gamma energy analyses, total alpha, and total organic carbon. The results are presented in Appendix A.

To initially determine the amount of radiation retained by the candidate filters, an initial test of $150 \mathrm{~mL}$ of $\mathrm{KE}$ composite was filtered through a $40-\mu \mathrm{m}$ PALL, and the filtrate was then filtered through a 5- $\mu \mathrm{m}$ Keystone Filter. A second 5- $\mu \mathrm{m}$ Keystone Filter was challenged with another $150 \mathrm{~mL}$ of $\mathrm{KE}$ composite. The filters and filtrate were submitted for gamma energy analysis and total alphe. The results are presented in Appendix B.

\footnotetext{
${ }^{4} \mathrm{HACH}$ is a registered trademark of HACH Company Corporation, Loveland, Colorado.

${ }^{5}$ PALL is a registered trademark of PALL Corporation, East Hills, New York.

${ }^{6}$ Keystone Filter is a division of Met-Pro Corporation, Hatfield, Pennsylvania.

${ }^{7}$ OMEGA is a registered trademark of Omega Technologies Company, Stamford, Connecticut.
} 


\section{RPP-RPT-30093, Rev. 0}

\section{RESULTS}

The filters used in all testing were $47-\mathrm{mm}$-diameter circular filters. The filters were then approximately $0.018 \mathrm{ft}^{2}$ of area.

\subsection{SCOUTING FILTRATION RESULTS}

Candidate filter media were subjected to a first batch of KE basin water to determine the respective media efficacy in achieving water clarity. Appendix $C$ presents the results of each filter media tested. Table I shows the reduction achieved with each filter media. Turbidity readings were accomplished at every $100 \mathrm{~mL}$ of challenge. The average final NTU column represents the average NTU readings over the volume filtered.

Table 1. Initial and Average Turbidity Measured During Scouting Tests.

\begin{tabular}{|c|l|c|c|c|}
\hline Volume (L) & \multicolumn{1}{|c|}{ Filter } & Inittal NTU & $\begin{array}{c}\text { Turbldity } \\
\text { Final NTU }\end{array}$ & $\begin{array}{c}\text { Reduction } \\
\text { (\%) }\end{array}$ \\
\hline 0.5 & $0.3-\mu$ m glass fiber & 7.7 & 0.62 & 92 \\
\hline 0.3 & $1-\mu$ m polyester & 11.3 & 0.47 & 96 \\
\hline 0.6 & $5-\mu$ m glass fiber & 6.8 & 0.18 & 97 \\
\hline 0.5 & $5-\mu$ m polyester & 7.3 & 0.67 & 91 \\
\hline 0.5 & $10-\mu$ m polyester & 7.5 & 3.23 & 57 \\
\hline 0.5 & $20-\mu$ m polyester & 7.5 & 2.89 & 61 \\
\hline 0.464 & $40-\mu$ m glass fiber & 6.8 & 0.23 & 97 \\
\hline
\end{tabular}

With the exception of the 10 and $20-\mu \mathrm{m}$ polyester filter media, the other media showed promise for a substantial reduction of turbidity.

The glass fiber media rated at $0.3 \mu \mathrm{m}$ and the polyester rated at $1 \mu \mathrm{m}$ were considered too low a cutoff point, i.e., more radioactive mass would accumulate on the filter versus a larger cutoff. The $5-\mu \mathrm{m}$ polyester did not achieve as good a reduction in turbidity as did the $5-\mu \mathrm{m}$ glass fiber. It was decided that the two filter media candidates would be down selected to the $40-\mu \mathrm{m}$ glass fiber (PALL filter) and the 5- $\mu \mathrm{m}$ glass fiber Keystone Filter.

\subsection{FILTRATION CHALLENGE RESULTS}

All filtration for the PALL-After the down selection to the PALL 40 (Catalog Number: 5ESC10770-3-U400Z-140) and the Keystone Filter 5 - $\mu \mathrm{m}$ glass fiber (TRI-NUC ${ }^{8}$ Catalog Number VCG-5) filters, $40 \mathrm{~L}$ of KE Basin water was collected to use as a challenge. The composite was made using $1 \mathrm{~L}$ each. The composite was used to establish a standard curve to estimate total suspended solids versus NTU values, also gamma energy analysis, total alpha, total organic

\footnotetext{
${ }^{8}$ TRI-NUC is a registered trademark of the Tri Nuclear Corporation, Ballston Lake, New York.
} 
carbon, and inductively coupled plasma spectroscopy for cations. The results are presented in Appendix A. To estimatc filter media retention of radionuclides for laboratory hood work safety, $150 \mathrm{~mL}$ of composite was filtered through each candidate media. The results are presented in Appendix B.

The analyses performed on the 40- $\mu \mathrm{m}$ filter and filtrate are presented in Appendix D, and the analyses performed on the 5 - $\mu \mathrm{m}$ filter and filtrate are presented in Appendix E. Appendix F contains the results of the PSD measurements for the KE Basin composite, the 40- $\mu \mathrm{m}$ filtrate, and the 5- $\mu \mathrm{m}$ filtrate (Letter CH2M-0403713, "Measurement of Particle Size Distributions in 105-KE Basin Water"). According to PALL the "DP (differential pressure) is critical and based upon the area and relatively ideal flow conditions of 2 to $4 \mathrm{gpm} / \mathrm{f}^{2 \text { " }}$ (e-mail from John Sica, PALL Power Operations, dated September 20, 2005). All of the Keystone and PALL filters tested were at a flow rate of $2 \mathrm{gpm} / \mathrm{ft}^{2}$.

Figure 3 presents the standard curve response for total suspended solids versus turbidity (NTU) with the $\mathrm{KE}$ Basin composite.

Figure 3. Composite Suspended Solids versus NTU Values.

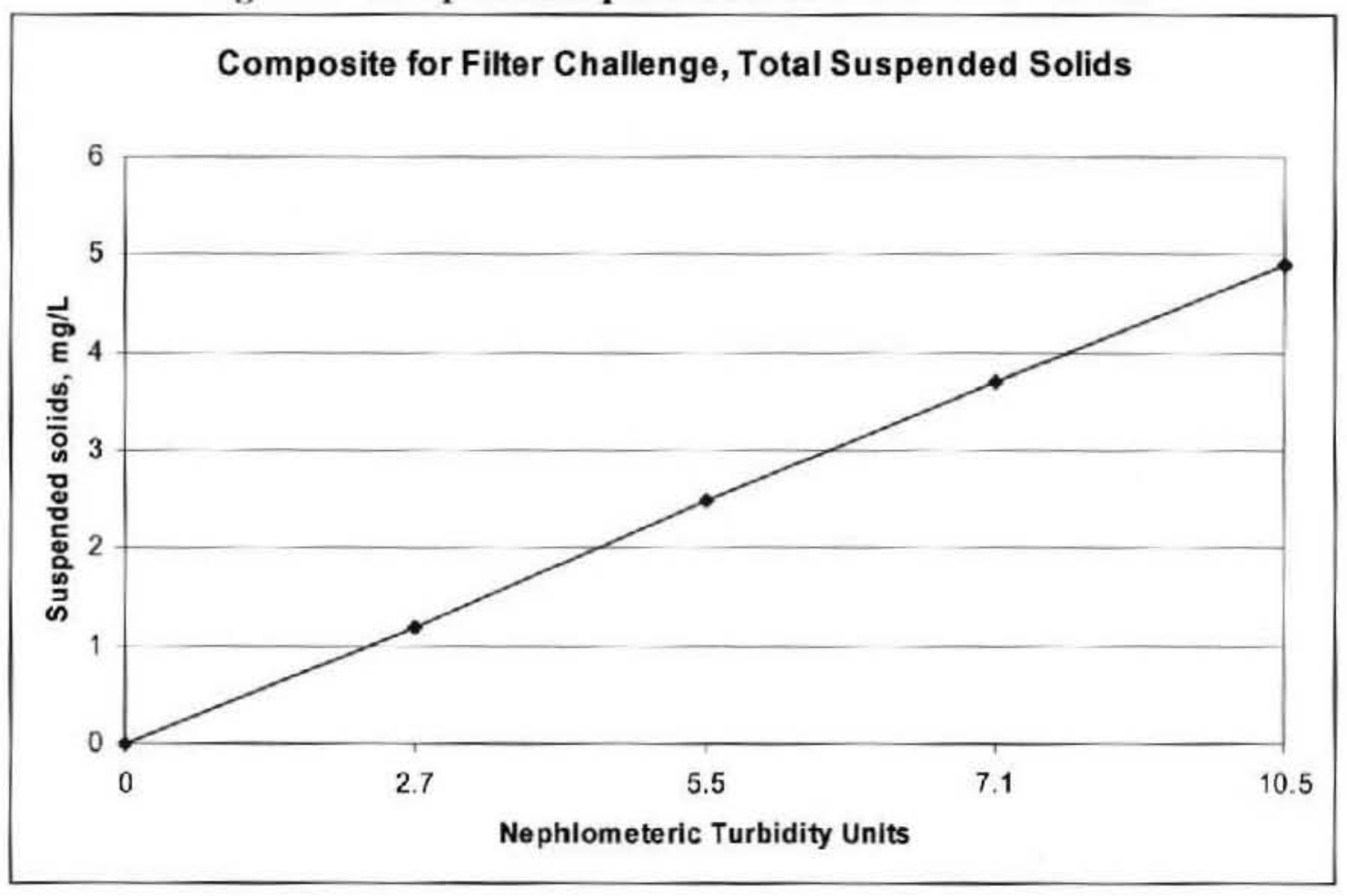

Suspended solids are regressed on NTU values, with the line equation of

$$
Y(\text { estimate })=0.376 x+0.541, r=0.86
$$

The $40-\mu \mathrm{m}$ filter was first challenged with KE Basin water and a total of $8.4 \mathrm{~L}$ was processed. The $40-\mu \mathrm{m}$ filter did not perform as would be expected; it did not reduce the turbidity as was 
first indicated by scouting tests, nor did it achieve the required delta psi of 15 to indicate filter exhaustion.

Figures 4 through 7 represent the $40-\mu \mathrm{m}$ filter effluent turbidity, turbidity retained by the filter, estimated solids retained on the filter using the regression equation (1), and the pressure differential across the filter.

Figure 4. Effluent Turbidity Using KE Basin Challenge (NTU Values).

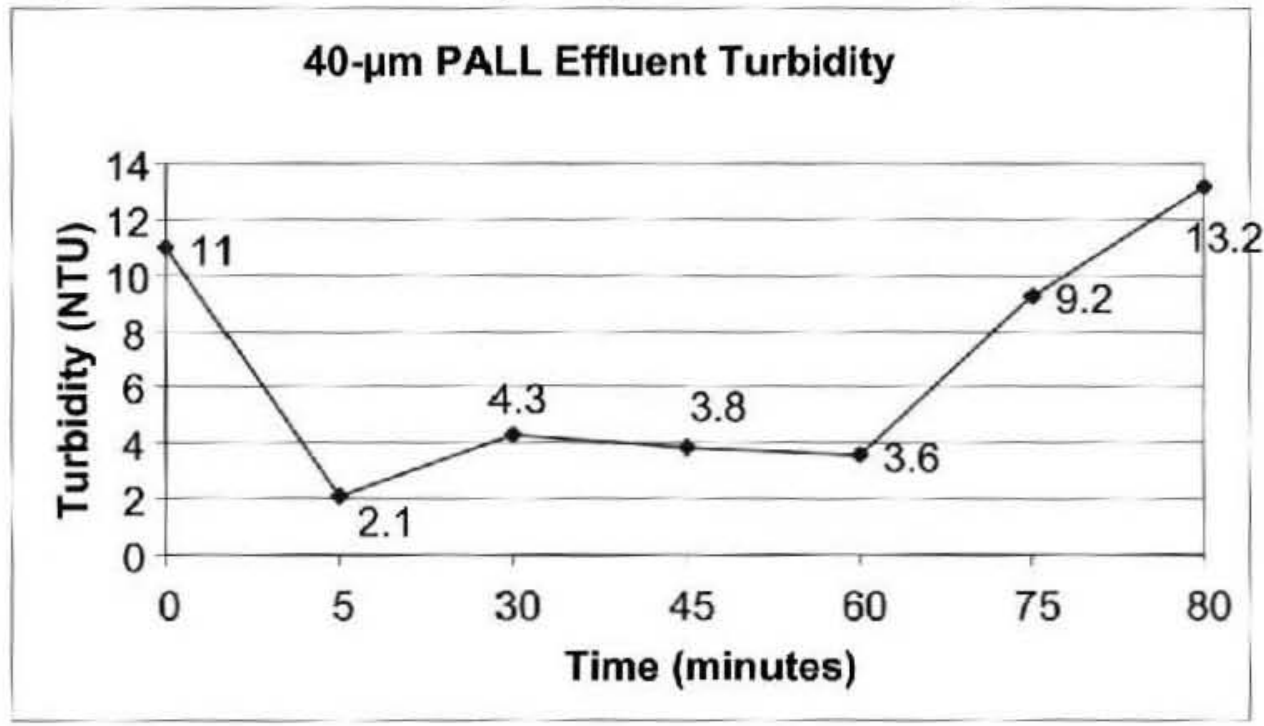

Figure 5. Composite Turbidity Retained by the Filter.

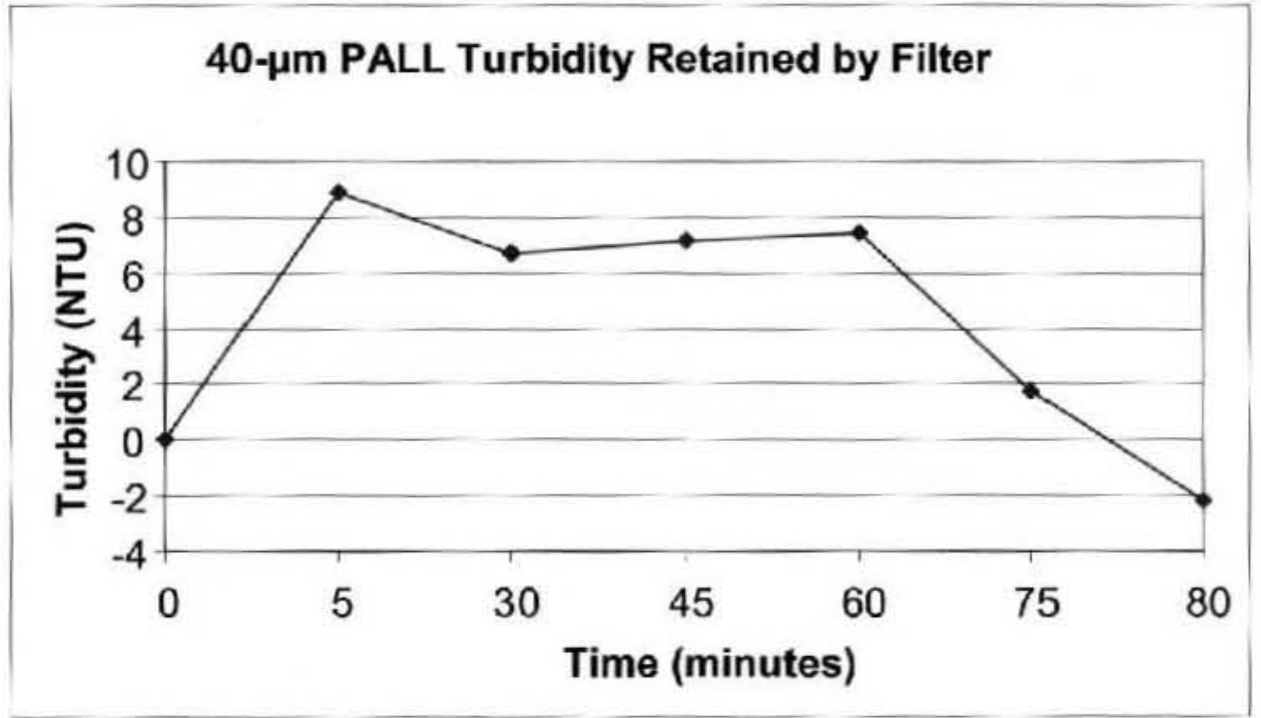




$$
\text { RPP-RPT-30093, Rev. } 0
$$

Figure 6. Estimated Solids Retained by the 40- $\mu \mathrm{m}$ PALL Filter.

\section{0- $\mu$ m PALL, Estimated Solids Retained on} Filter

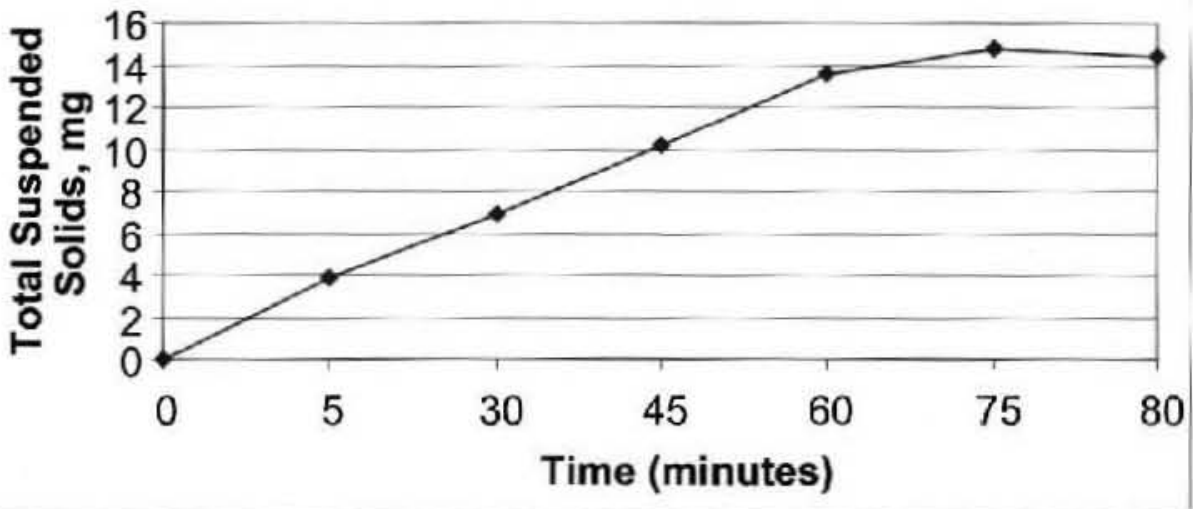

Figure 7. Pressure Differential Across the 40- $\mu \mathrm{m}$ PALL Filter.

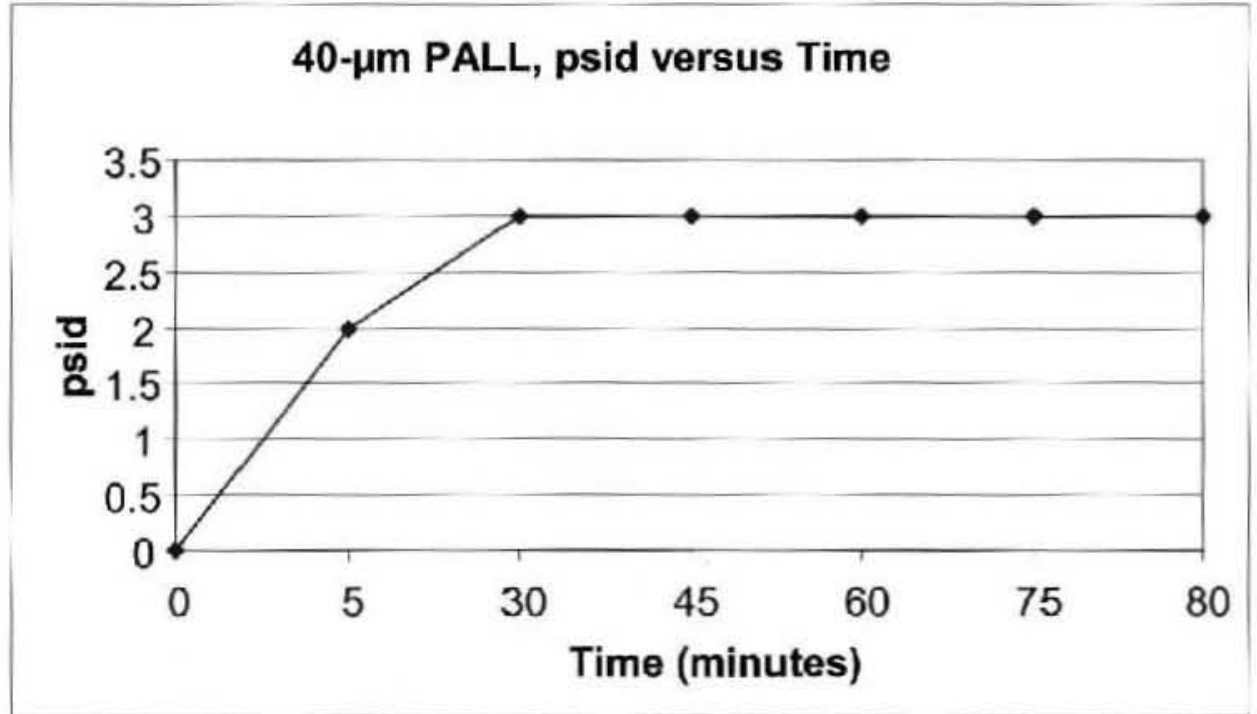

Table 2 presents the radionuclide data using the composite analyses and analyses from the filter digest. 
Table 2. Radionuclides Retained on the 40- $\mu$ m PALL Filter.

\begin{tabular}{|c|c|c|c|c|c|}
\hline $2 \quad \therefore \quad \therefore$ & \multicolumn{2}{|c|}{ Influent } & $\quad \quad \quad \quad$ & \multicolumn{2}{|c|}{ Filter } \\
\hline KE Composite & $\begin{array}{c}\mu \mathrm{Cl} / \mathrm{mL} \\
(8.4 \mathrm{~L} \text { Total })\end{array}$ & $\begin{array}{l}\text { Total through } \\
\text { Filter }(\mu C l)\end{array}$ & $\begin{array}{c}\text { Total through } \\
\text { Filter (g) }\end{array}$ & HCi/fiter & $\begin{array}{c}\text { Total on Filter } \\
\text { (g) }\end{array}$ \\
\hline${ }^{80} \mathrm{Co}$ & $5.23 \mathrm{E}-07$ & $4.39 \mathrm{E}-03$ & $3.99 \mathrm{E}-12$ & $5.64 \mathrm{E}-03$ & $5.13 \mathrm{E}-12$ \\
\hline${ }^{137} \mathrm{Cs}$ & $6.96 \mathrm{E}-04$ & 5.85 & 5.97E-08 & 2.13 & $2.18 \mathrm{E}-08$ \\
\hline${ }^{152} \mathrm{Eu}$ & ND & ND & ND & 1.73E-03 & $9.11 \mathrm{E}-12$ \\
\hline${ }^{154} \mathrm{Eu}$ & $7.03 \mathrm{E}-06$ & $5.91 \mathrm{E}-02$ & $3.94 \mathrm{E}-10$ & $5.69 \mathrm{E}-02$ & $3.79 \mathrm{E}-10$ \\
\hline${ }^{155} \mathrm{Eu}$ & ND & ND & ND & $1.37 \mathrm{E}-02$ & $9.79 \mathrm{E}-08$ \\
\hline${ }^{2+1} \mathrm{Am}$ & $1.26 \mathrm{E}-04$ & 1.06 & 3.31E-07 & $9.90 \mathrm{E}-01$ & $3.09 \mathrm{E}-07$ \\
\hline 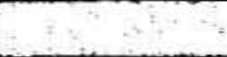 & $+2+8=$ & $2 \ldots$ & $\therefore \ldots$ & $\therefore \ldots$ & 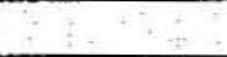 \\
\hline Total alpha & $1.84 \mathrm{E}-04$ & $1.55^{b}$ & & $2.11^{*}$ & \\
\hline
\end{tabular}

Estimated using specific activity for the radionuclide of interest.

A spike was not rum therefore the discrepancy could be due to self adsorption on the counting dish due to dissolved solids. A larger sample volume was needed which contained more dissolved solids; this would lead to lower counts due to solids concentration that would adsorb the alpha energy shielding it from the counter.

"The dissolved filter required a smaller sample volume and therefore less solids on the counting dish and a more accuratc count.

Table 3 presents the analytes above detection limit in the composite and the effluent after the $40-\mu \mathrm{m}$ PALL filter filtrate. The mass of each analyte captured by the filter is calculated by difference.

Table 3. Mass of Analytes Above Detection Limit Captured by the 40- $\mu \mathrm{m}$ PALL Fiter.

\begin{tabular}{|c|c|c|c|c|c|}
\hline \multicolumn{3}{|c|}{ Influent } & \multicolumn{2}{|c|}{ Emuent } & \multirow{2}{*}{$\begin{array}{l}\text { Mass } \\
\text { Retained on } \\
\text { Fllter (mg) }\end{array}$} \\
\hline Analyte & $\begin{array}{c}\text { Concentration } \\
(\mathrm{mg} / \mathrm{L})\end{array}$ & $\begin{array}{l}\text { Total Volume } \\
8.4 \mathrm{~L} \text { Auralyte } \\
\text { Mass (mg) }\end{array}$ & $\begin{array}{c}\text { Concentration } \\
(\mathrm{mg} / \mathrm{L})\end{array}$ & $\begin{array}{l}\text { Total Volume } \\
8.4 \text { L Analyte } \\
\text { Mass (mg) }\end{array}$ & \\
\hline Aluminum & 0.45 & 3,780 & $4.15 \mathrm{E}-02$ & 348 & 3,432 \\
\hline Boron & $7.34 \mathrm{E}-02$ & 616 & $4.93 \mathrm{~B}-02$ & 414 & 202 \\
\hline Calcium & 0.992 & 8,332 & 0.552 & 4,636 & 3,696 \\
\hline Cadmium & $3.46 \mathrm{E}-03$ & 29.1 & $3.46 \mathrm{E}-03$ & 29.1 & 0 \\
\hline Iron & 1.237 & 10,390 & $8.72 \mathrm{E}-02$ & 733 & 9,657 \\
\hline Potassium & 0.319 & 2,680 & 0.319 & 2,680 & 0 \\
\hline Magnesium & $4.58 \mathrm{E}-02$ & 385 & $3.19 \mathrm{E}-02$ & 268 & 117 \\
\hline Sodium & 1.084 & 9,106 & 0.742 & 6,232 & 2,874 \\
\hline Sulfur & 0.444 & 3,730 & 0.444 & 3,730 & 0 \\
\hline Silicon & 1.241 & 10,424 & 0.915 & 7,686 & 2,738 \\
\hline Titanium & $7.89 \mathrm{E}-03$ & 66.3 & $7.89 \mathrm{E}-03$ & 66.3 & 0 \\
\hline Uraniumt & 0.535 & 4,494 & 0.535 & 4,494 & 0 \\
\hline Zinc & $1.25 \mathrm{E}-02$ & 105 & 7.67E-03 & 64 & 41 \\
\hline
\end{tabular}


The $5-\mu \mathrm{m}$ filter processed a total of $4.8 \mathrm{~L}$ and did achieve both turbidity reduction and a delta psi of 15 at which time the run was terminated. Figures 8 through 11 represent the $5-\mu \mathrm{m}$ filter effluent turbidity, turbidity retained by the filter, estimated solids retained on the filter using the regression equation (1), and the pressure differential across the filter.

Figure 8. Effluent Turbidity Using KE Basin Challenge.

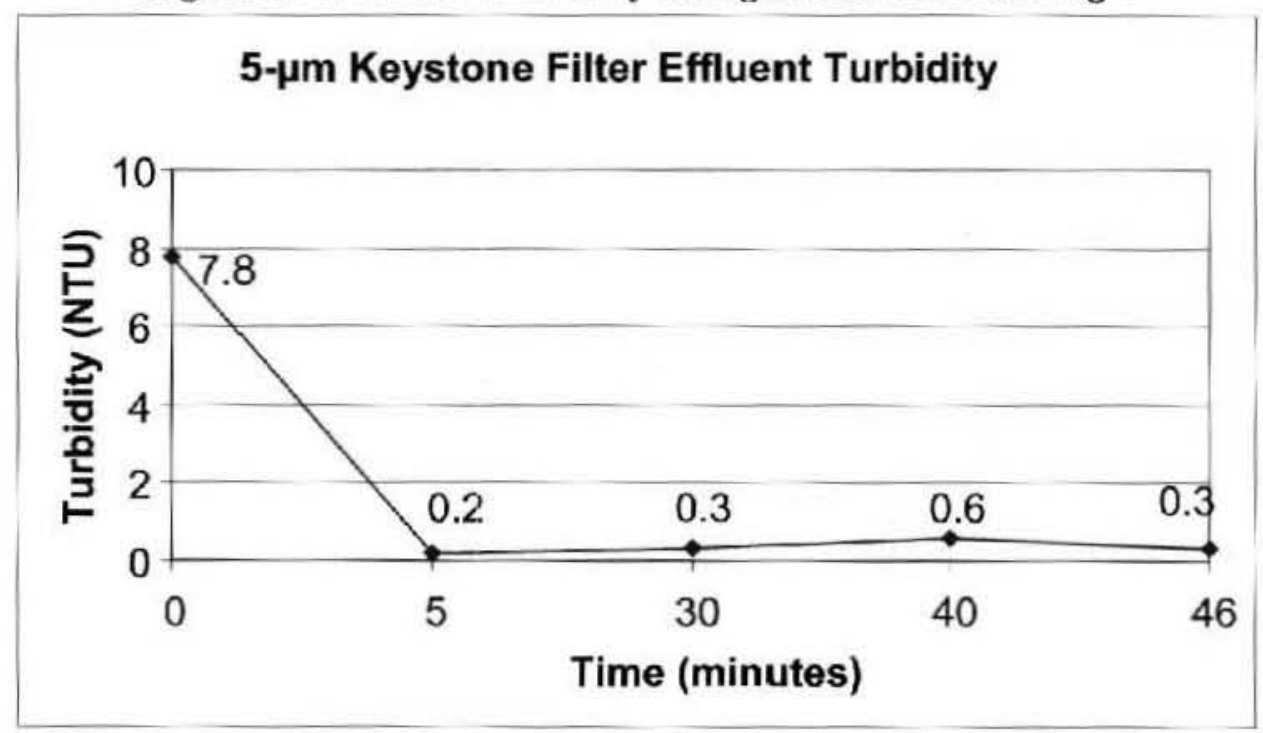

Figure 9. Composite Turbidity Retained by the Filter.

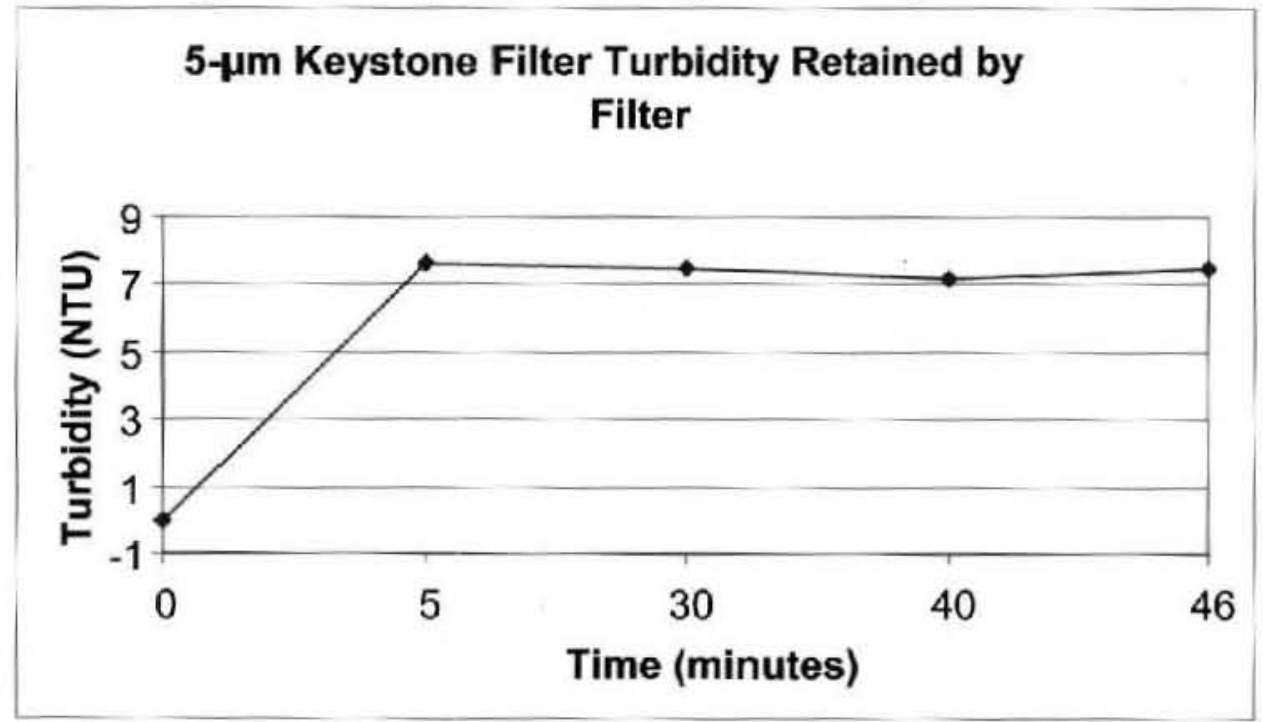


Figure 10. Estimated Solids Retained by the 5- $\mu \mathrm{m}$ Filter.

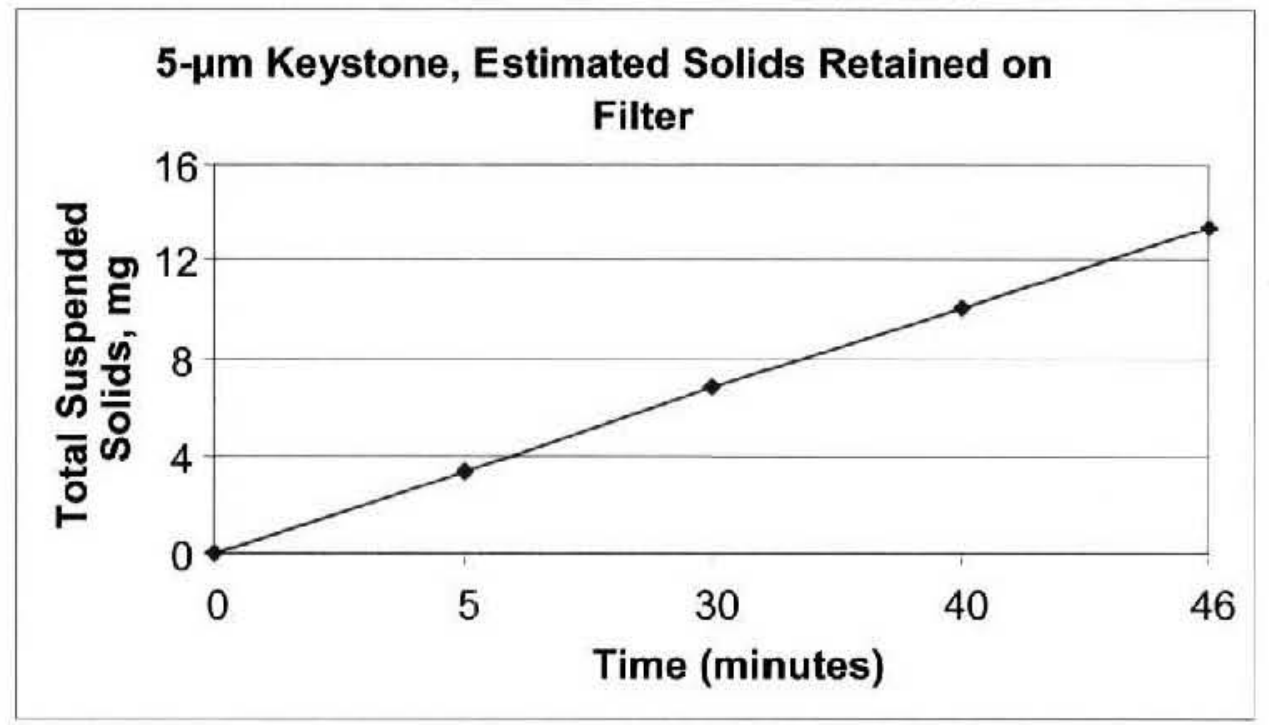

Figure 11. Pressure Differential Across the 5- $\mu \mathrm{m}$ Filter.

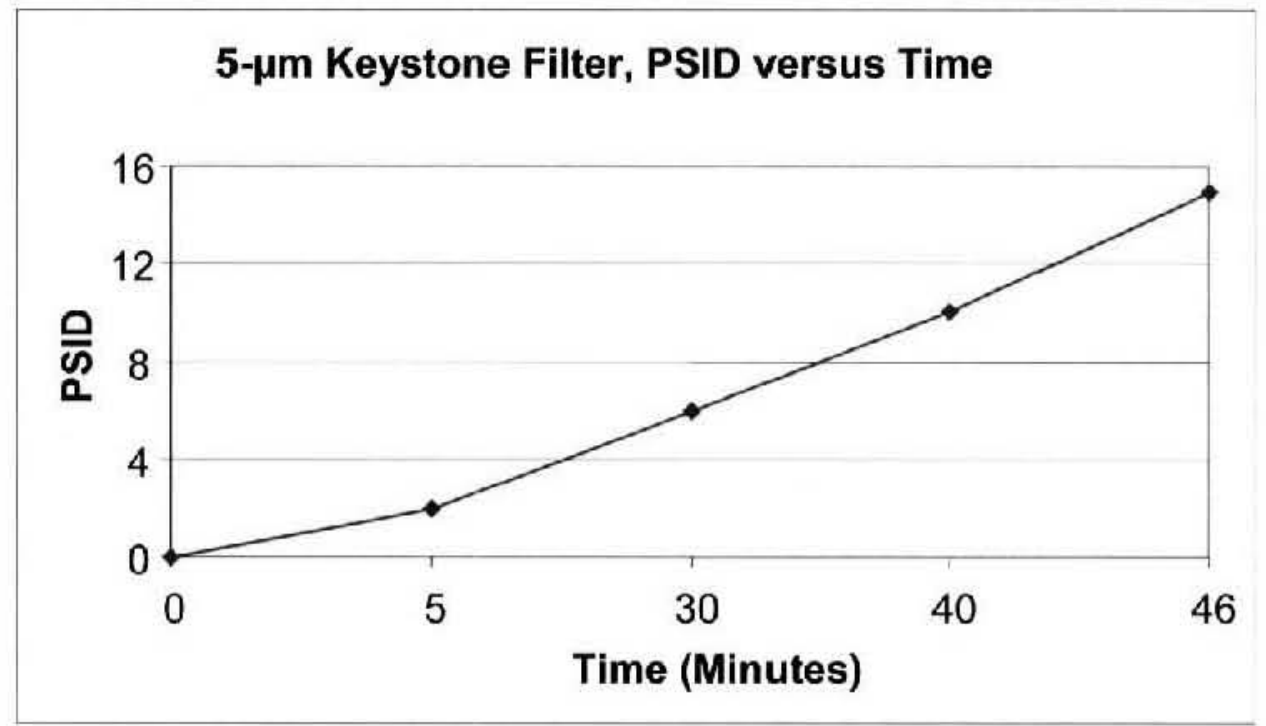

Tables 4 and 5 represent the analytes and radionuclides captured by the 5 - $\mu \mathrm{m}$ filter.

\subsection{PARTICLE SIZE DISTRIBUTION ANALYSES}

A PSD measurement was carried out on the KE Basin composite, the 40- $\mu \mathrm{m}$ PALL filtrate, and the $5-\mu \mathrm{m}$ Keystone Filter glass fiber filtrate. Each sample was interrogated with and without sonication. The complete PSD analysis is reported in Appendix F. Particles were measured in the composite and the $40-\mu \mathrm{m}$ PALL filter filtrate. The 5- $\mu \mathrm{m}$ Keystone Filter filtrate was 
immeasurable with the PSD instrument. Most likely there were not a sufficient number (volume) of particles.

Table 4. Mass of Analytes Above Detection Limit Captured by the 5- $4 \mathrm{~m}$ Filter.

\begin{tabular}{|c|c|c|c|c|c|}
\hline \multicolumn{3}{|c|}{ Influent } & \multicolumn{2}{|c|}{ Efmuent } & \\
\hline Analyte & $\begin{array}{c}\text { Concentration } \\
\text { (mg/L) }\end{array}$ & $\begin{array}{c}\text { Tatal } \\
\text { Volume } \\
4.8 \mathrm{~K} \\
\text { Analyte } \\
\text { Mass (mg) }\end{array}$ & $\begin{array}{c}\text { Concentration } \\
(\mathrm{mg} / \mathrm{L})\end{array}$ & $\begin{array}{l}\text { Total Volume } \\
4.8 \mathrm{~L} \\
\text { Analyte Mass } \\
\text { (mg) }\end{array}$ & $\begin{array}{l}\text { Mass } \\
\text { Retained on } \\
\text { Filter (mg) }\end{array}$ \\
\hline Aluminum & 0.45 & 2,160 & $<2.7 \mathrm{E}-02$ & $\operatorname{LTD}^{2}(0.13)$ & 2,159 \\
\hline Boron & $7.34 \mathrm{E}-02$ & 352 & $5.4 \mathrm{E}-02$ & 259 & 93 \\
\hline Calcium & 0,992 & 4,761 & 0.953 & 4,574 & 187 \\
\hline Cadmium & $3.46 \mathrm{E}-03$ & 17 & $\leq 3 \mathrm{E}-03$ & $\operatorname{LTD}(0,01)$ & 16.99 \\
\hline Iron & 1.237 & 5,938 & $<1.3 \mathrm{E}-02$ & $\operatorname{LTD}(0.06)$ & $5,937.94$ \\
\hline Potassium & 0.319 & 1,531 & $<0.295$ & $\operatorname{LTD}(1,42)$ & 1,530 \\
\hline Magnesium & $4.58 \mathrm{E}-02$ & 220 & $8.88 \mathrm{E}-02$ & 426 & -206 \\
\hline Sodium & 1.084 & 5,203 & 1.63 & 7,824 & $-2,621$ \\
\hline Sulfur & 0.444 & 2,131 & $<5.8 \mathrm{E}-02$ & $\operatorname{LTD}(0.28)$ & 2,131 \\
\hline Silicon & 1,241 & 5,957 & 3.14 & 15,072 & $-9,115$ \\
\hline Titanium & $7.89 \mathrm{E}-03$ & 38 & $\angle 2 \mathrm{E}-03$ & $\operatorname{LTD}(0.01)$ & .37 .99 \\
\hline Uranium & 0.535 & 2,568 & $<3.1 \mathrm{E}-02$ & LTD $(0.15)$ & $2,567.85$ \\
\hline Zinc & $1.25 \mathrm{E}-02$ & 60 & $<4 \mathrm{E}-03$ & $\operatorname{LTD}(0.02)$ & 59.98 \\
\hline
\end{tabular}

aTD is less than the detection limit; the assumption is that the difference between the mass at the LTD level and the influent mass was captured by the filter, represented in ().

Table 5. Radionuclides Retained on the 5- $\mathrm{mm}$ Keystone Filter.

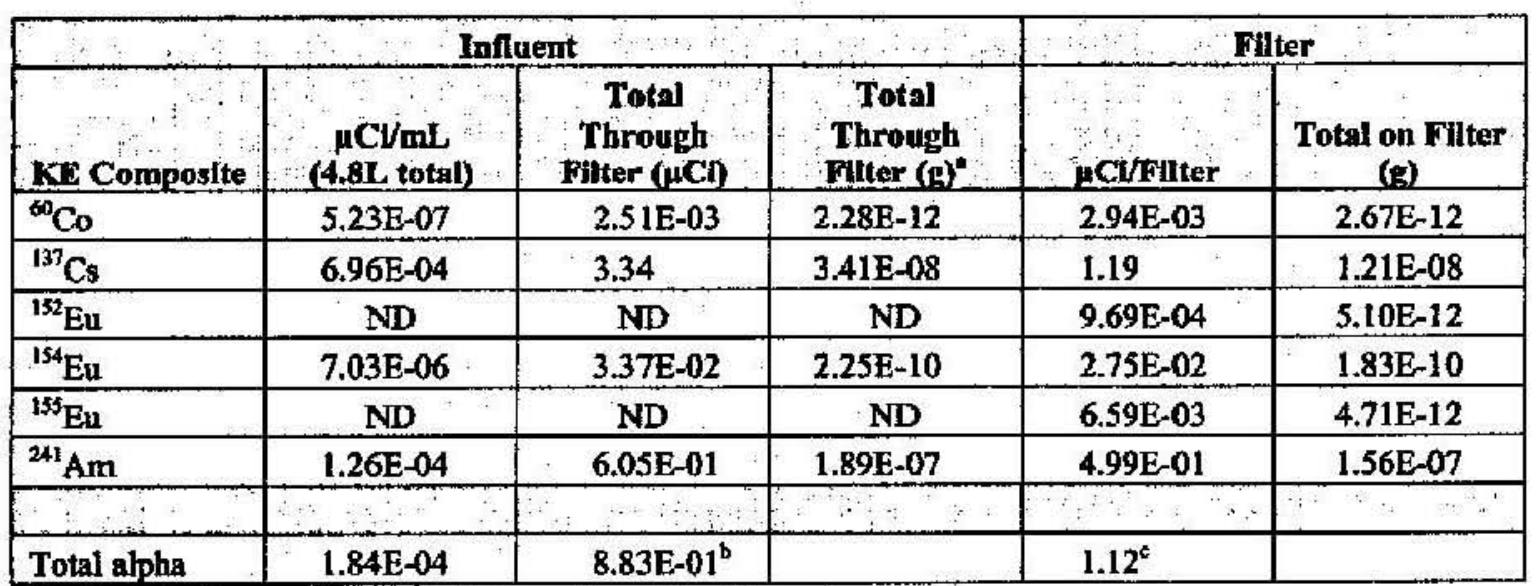

Estimated using specific activity for the radionuclide of interest.

- A spike was not run and therefore the discrepancy could be due to self adsorption on the counting dish due to dissolved solids. A larger sample volume was needed, which contained more dissolved solids; this would lead to lower counts due to solids concentration that would adsorb the alpha energy shiclding it from the counter.

${ }^{c}$ The dissolved filter required a smaller sample volume and therefore less solids on the counting dish therefore a more accurate count. 


$$
\text { RPP-RPT-30093, Rev. } 0
$$

Figure 12 presents the volume-based PSD measurement of the KE composite; Figure 13 presents the volume-based PSD measurement of the 40- $\mu$ m PALL filter filtrate.

Figure 12. Volume-based Particle Size Distributions of KE-Basin Water Composite. (Average of triplicate measurements.)

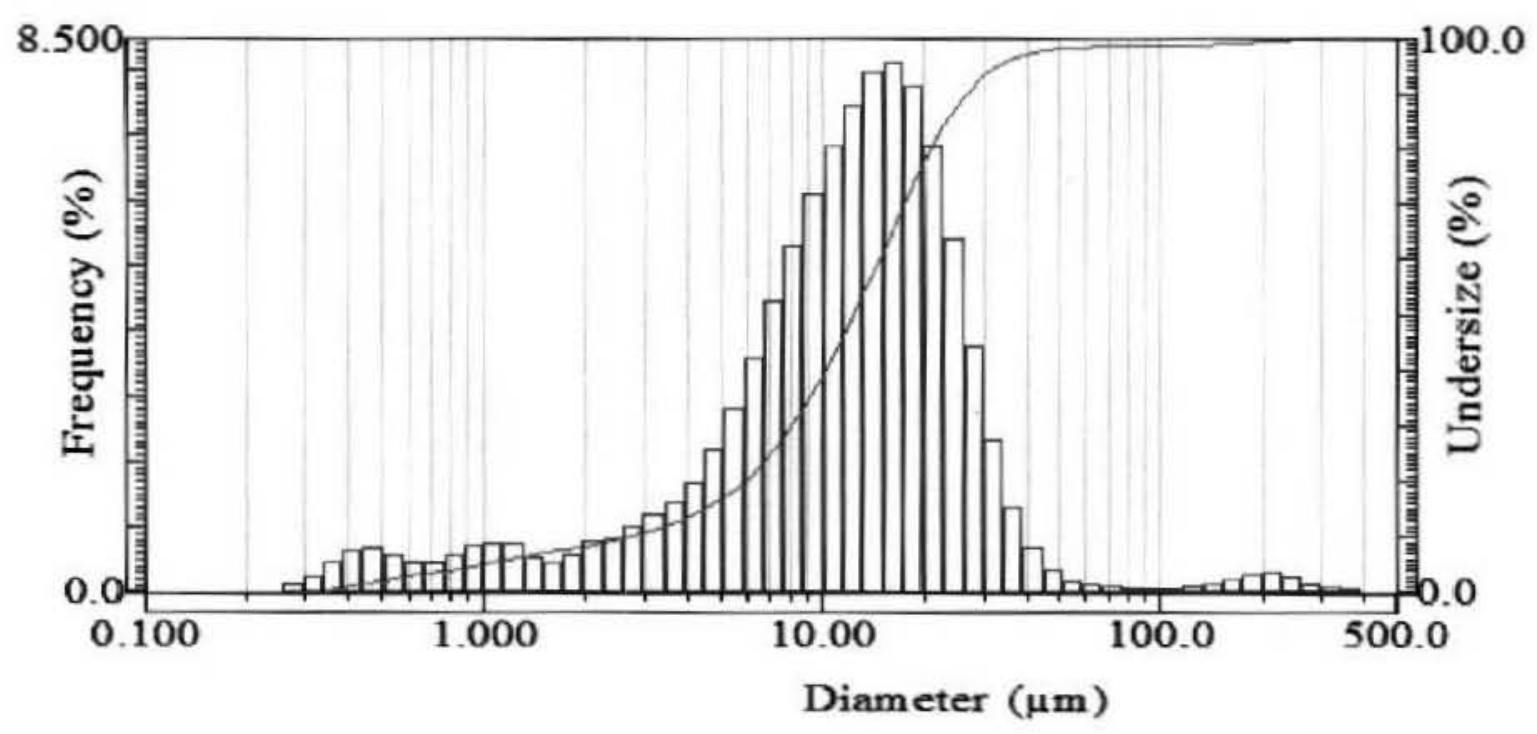

Figure 13. Volume-based Particle Size Distributions of $40-\mu \mathrm{m}$ Filtrate. (Average of triplicate measurements.)

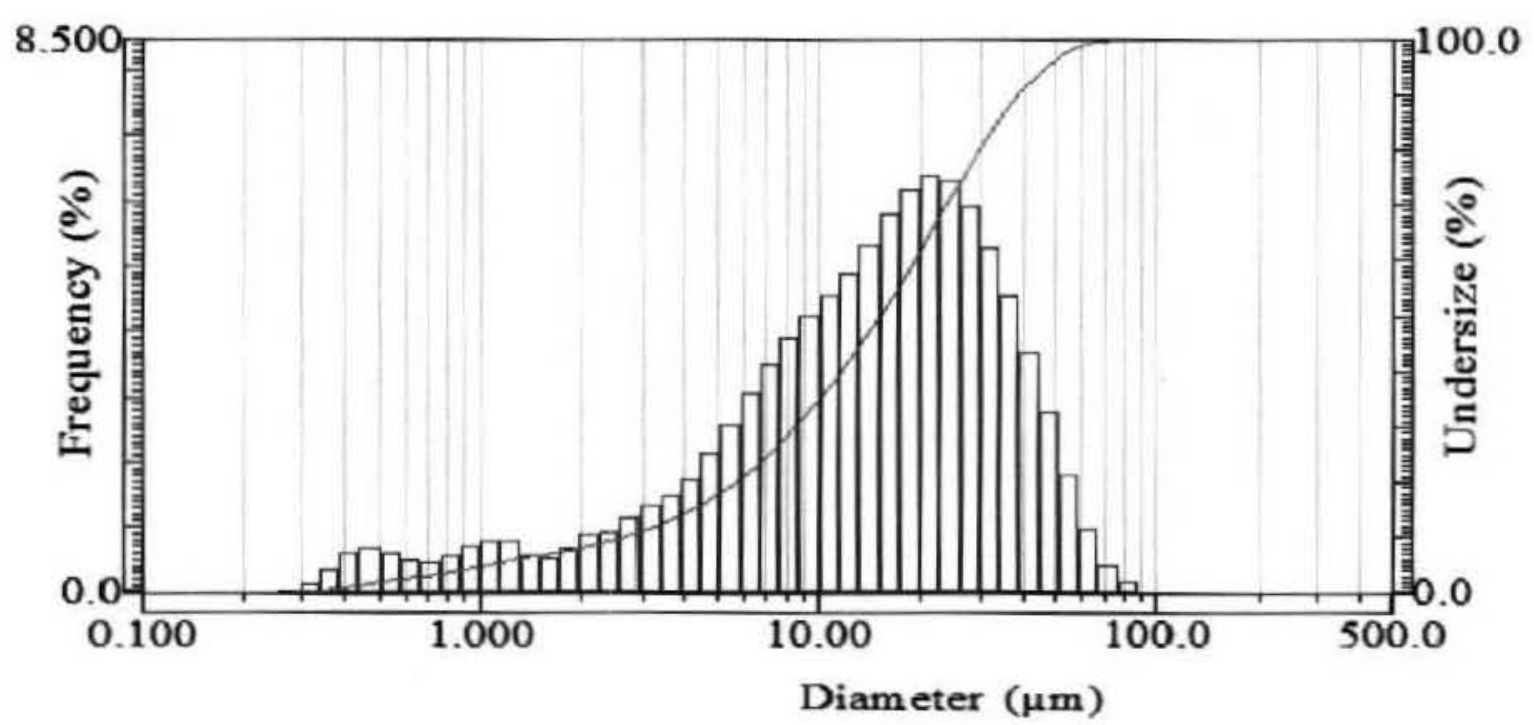




\subsection{FURTHER FILTRATION TESTING (10-MICRON GLASS FIBER)}

After analyzing the data above, it was decided by the KE Basin engineers that a $10-\mu \mathrm{m}$ glass fiber filter from Keystone (Part Number: VCG-10) and PALL (Part Number: 5ESC10770$3 \mathrm{U} 100 \mathrm{Z}-140$ ) would be challenged with the remainder of the KE Basin sample used in the previous challenges. To conserve budget, the inductively coupled plasma-mass spectroscopy was not carried out, however the total alpha, GEA, and PSD were analyzed.

Figures 14 through 17 represent the Keystone $10-\mu \mathrm{m}$ glass fiber filter response to KE Basin challenge. Figures 18 through 21 represent the PALL $10-\mu \mathrm{m}$ filter response to KE Basin challenge.

Figure 14. Effluent Turbidity From 10- $\mu \mathrm{m}$ Keystone Filter Using KE Basin Challenge.

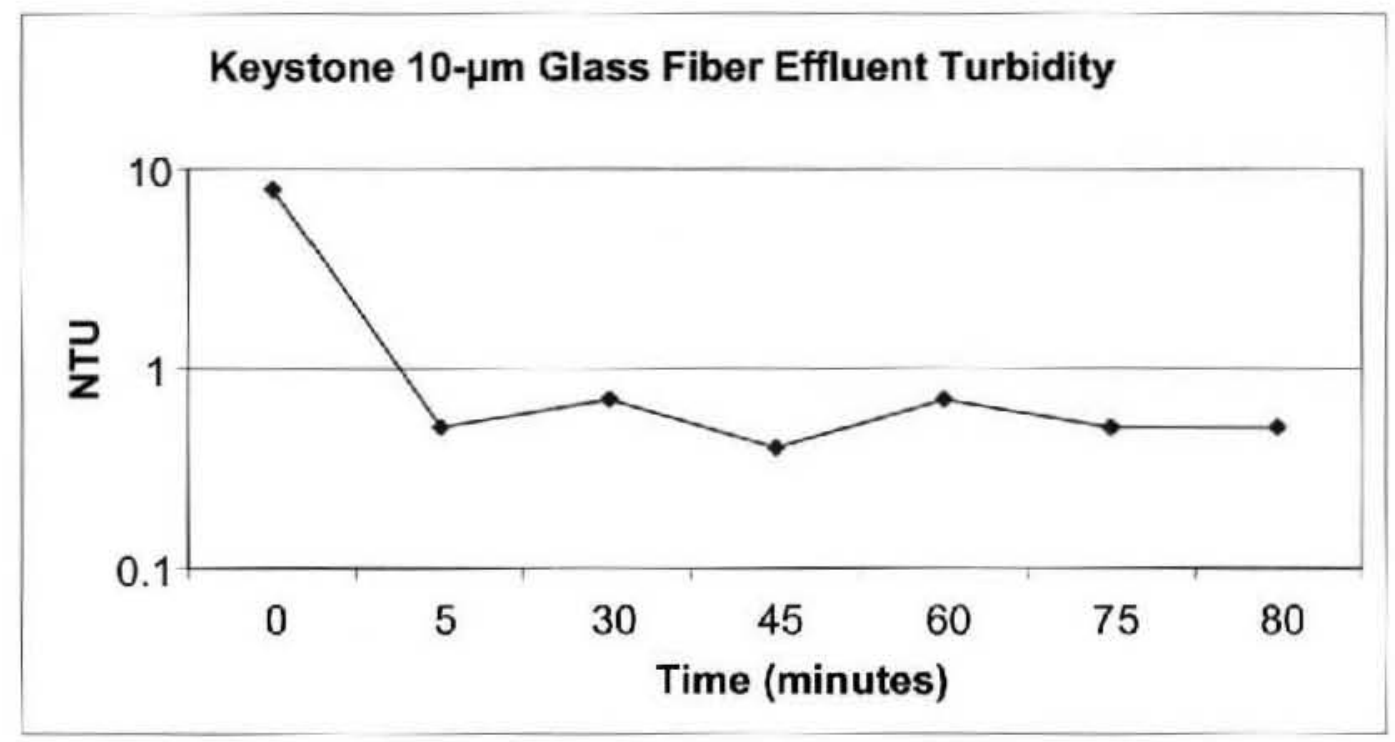


RPP-RPT-30093, Rev. 0

Figure 15. Composite Turbidity Retained by 10- $\mu \mathrm{m}$ Keystone Filter.

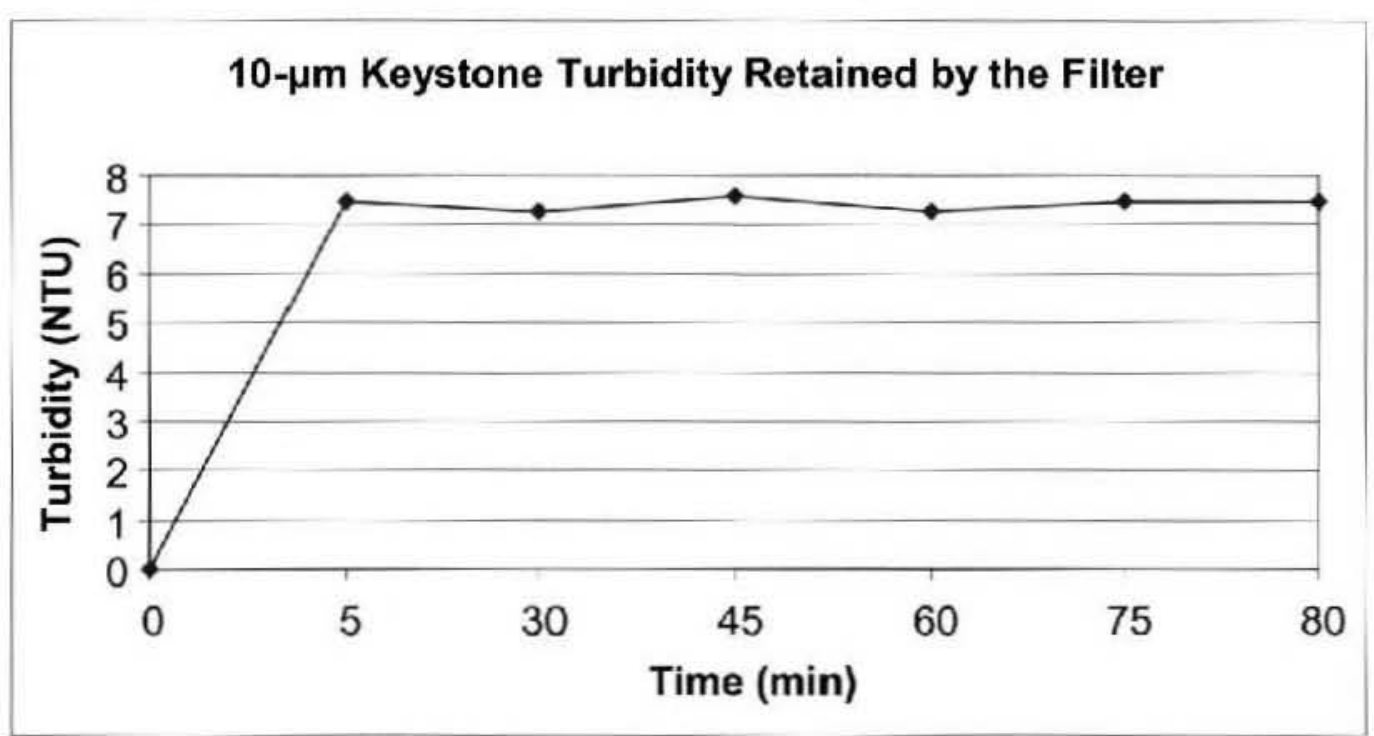

Figure 16. Estimated Solids Retained by the $10-\mu \mathrm{m}$ Keystone Filter.

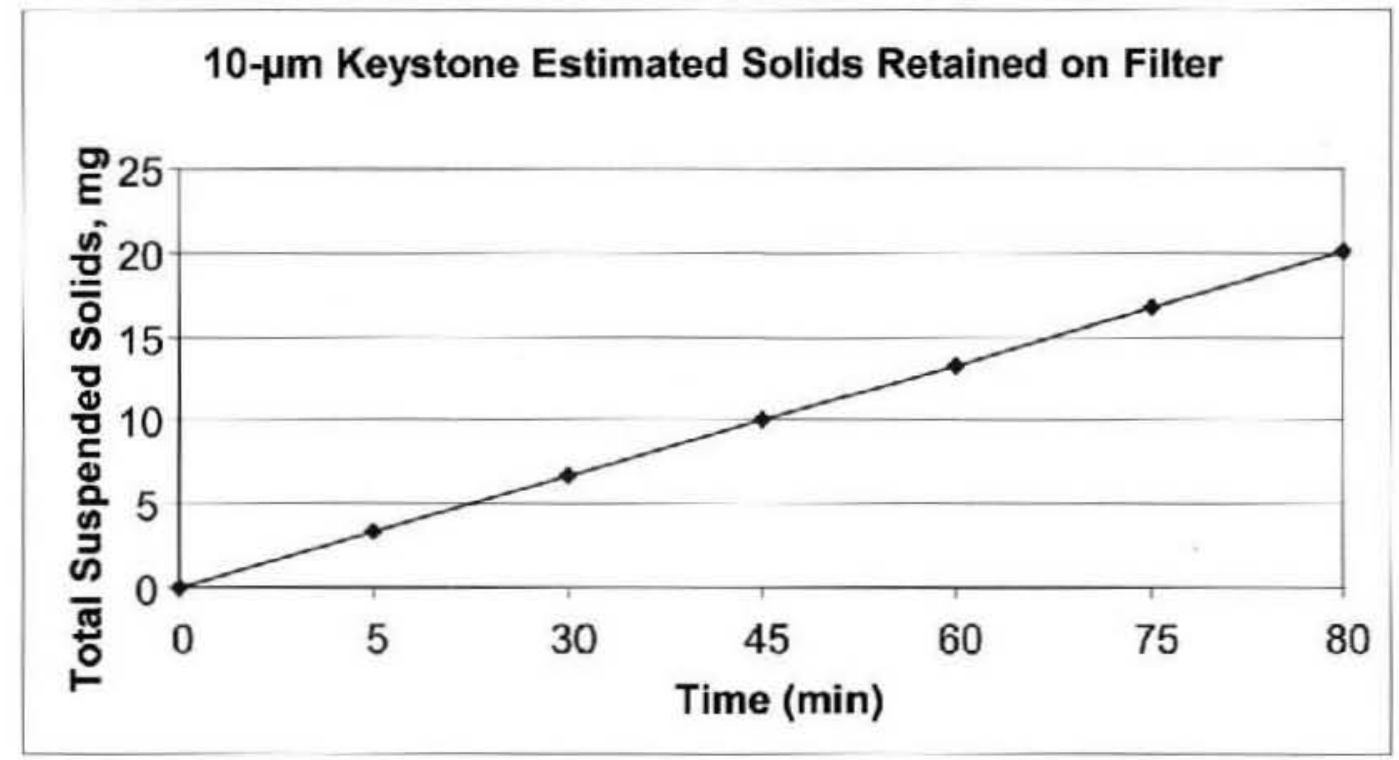


RPP-RPT-30093, Rev. 0

Figure 17. Pressure Differential Across the 10- $\mu \mathrm{m}$ Keystone Filter.

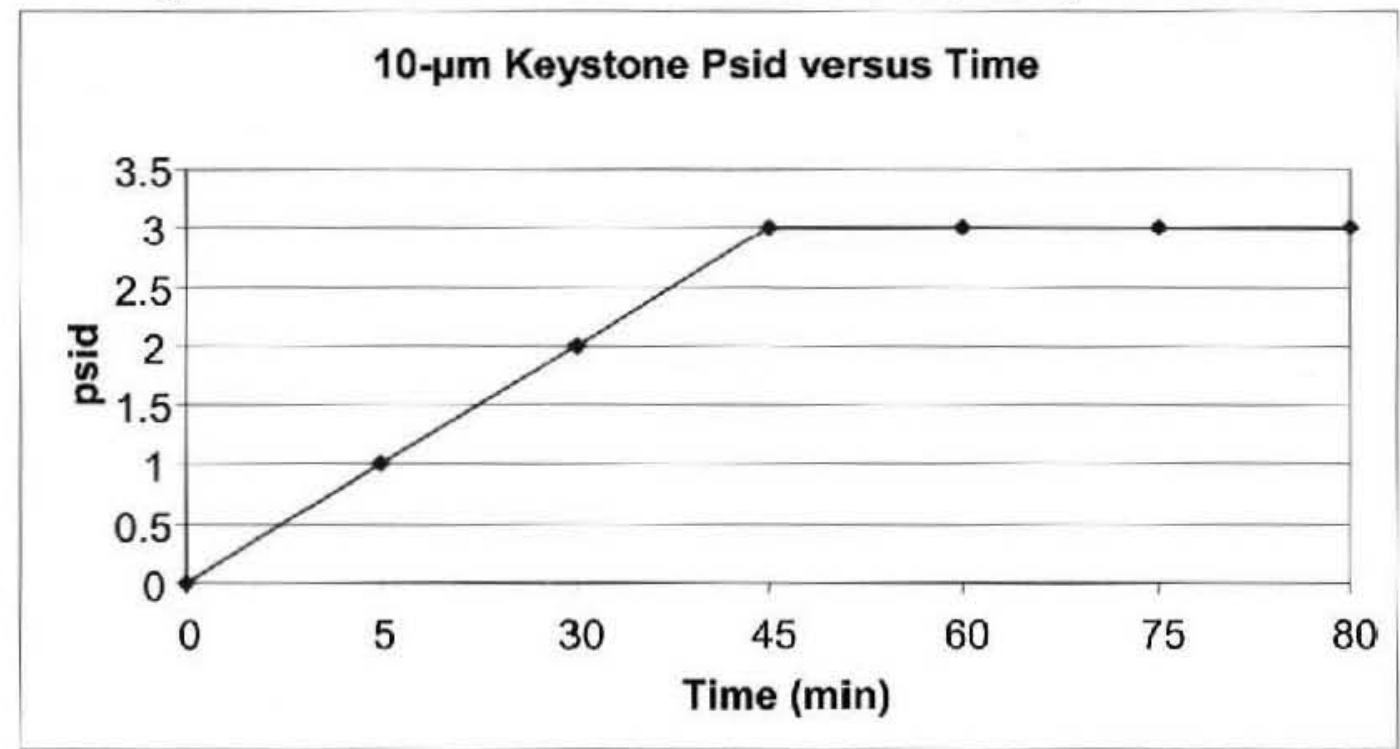

Figure 18. Effluent Turbidity From 10-- $\mu$ m PALL Using KE Basin Challenge.

PALL 10- $\mu \mathrm{m}$ Glass Fiber Effluent Turbidity

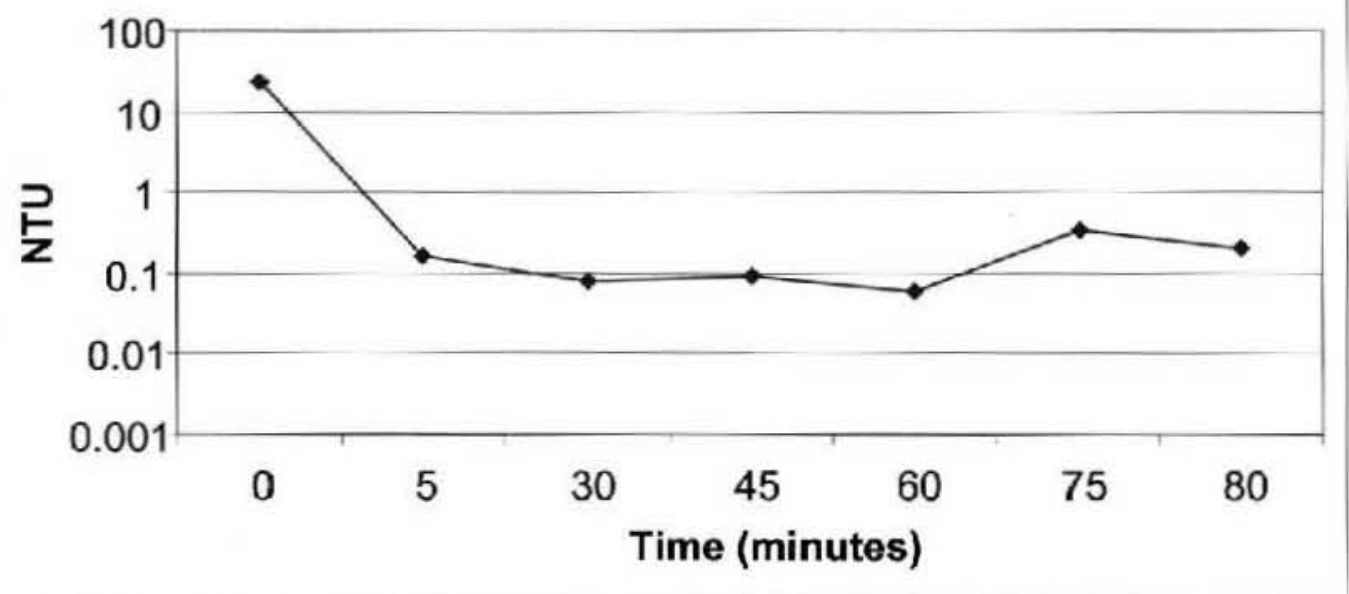




$$
\text { RPP-RPT-30093, Rev. } 0
$$

Figure 19. Composite Turbidity Retained by 20- $\mu$ m PALL Filter.

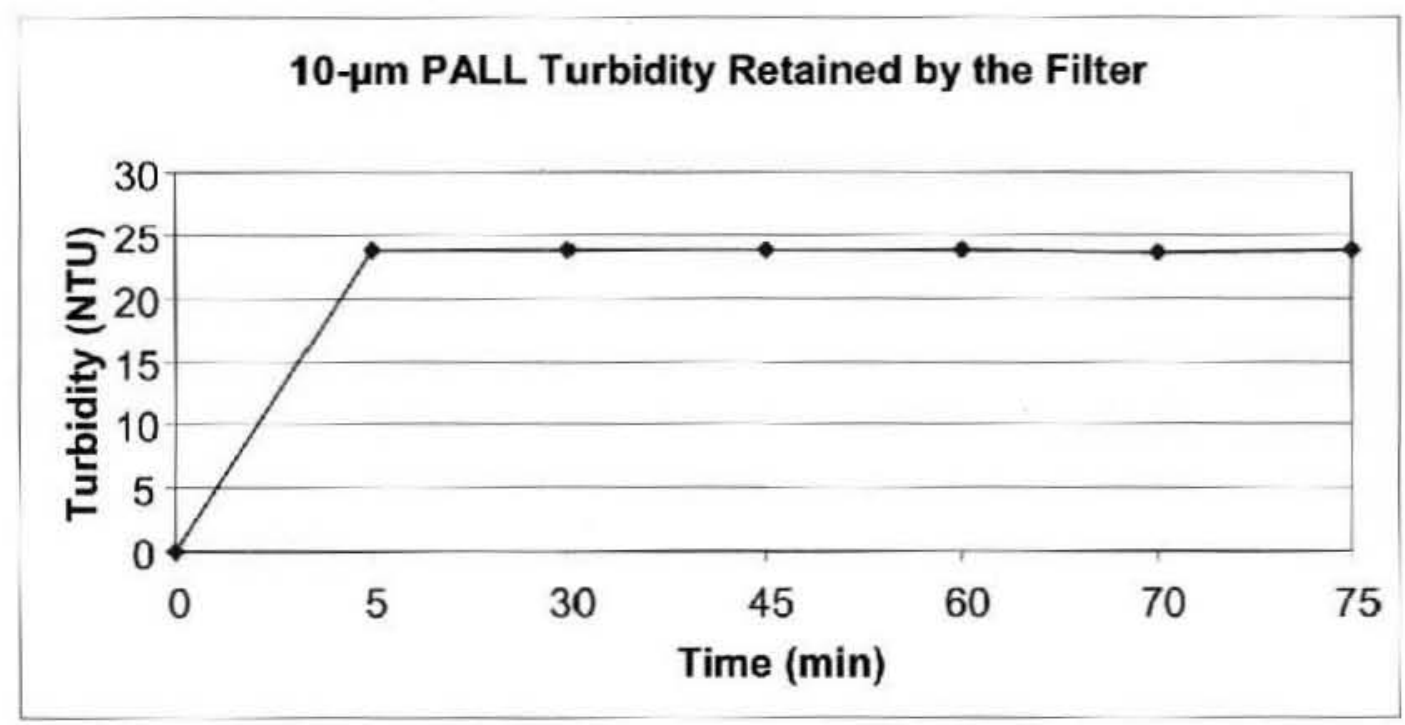

Figure 20. Estimated Solids Retained by the 10- $\mu \mathrm{m}$ PALL Filter.

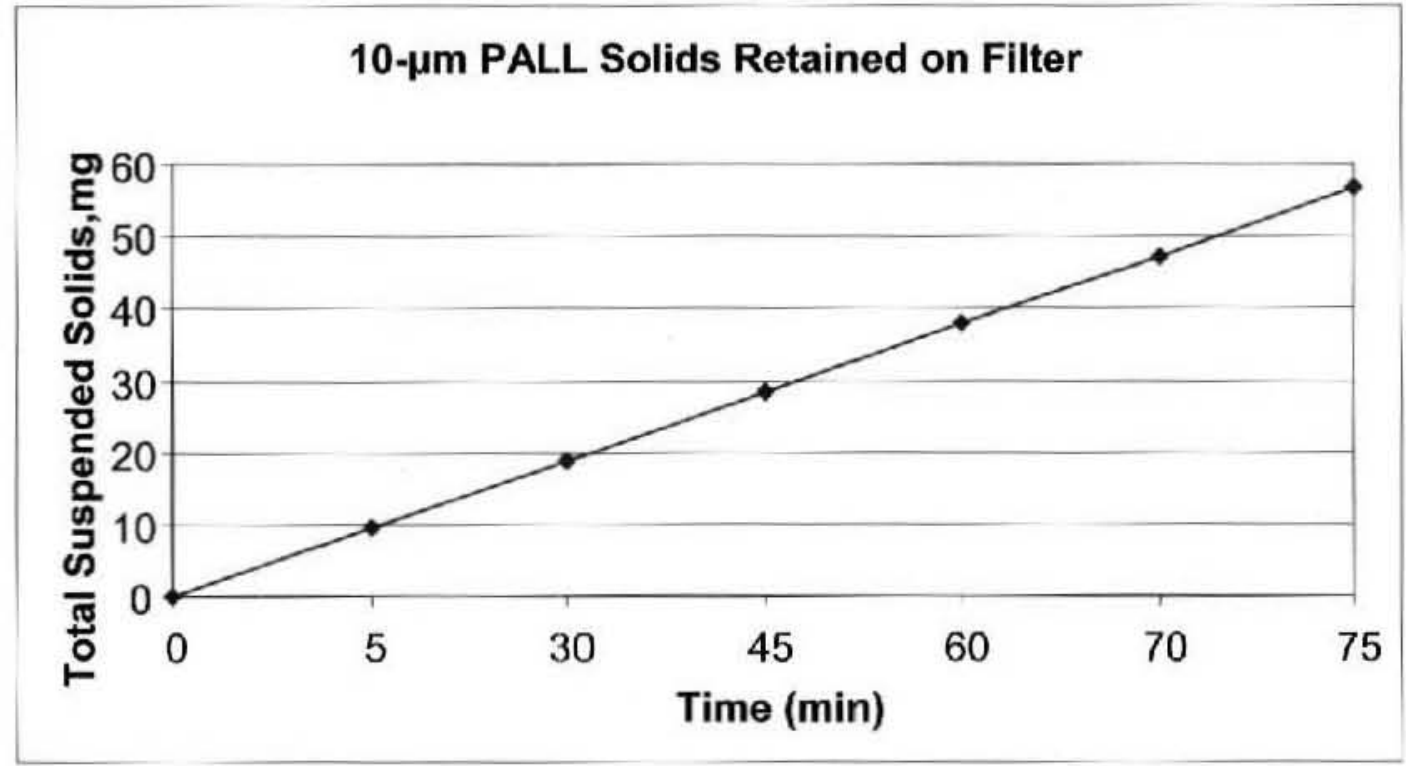


RPP-RPT-30093, Rev. 0

Figure 21. Pressure Differential Across the 10- $\mu \mathrm{m}$ PALL Filter.

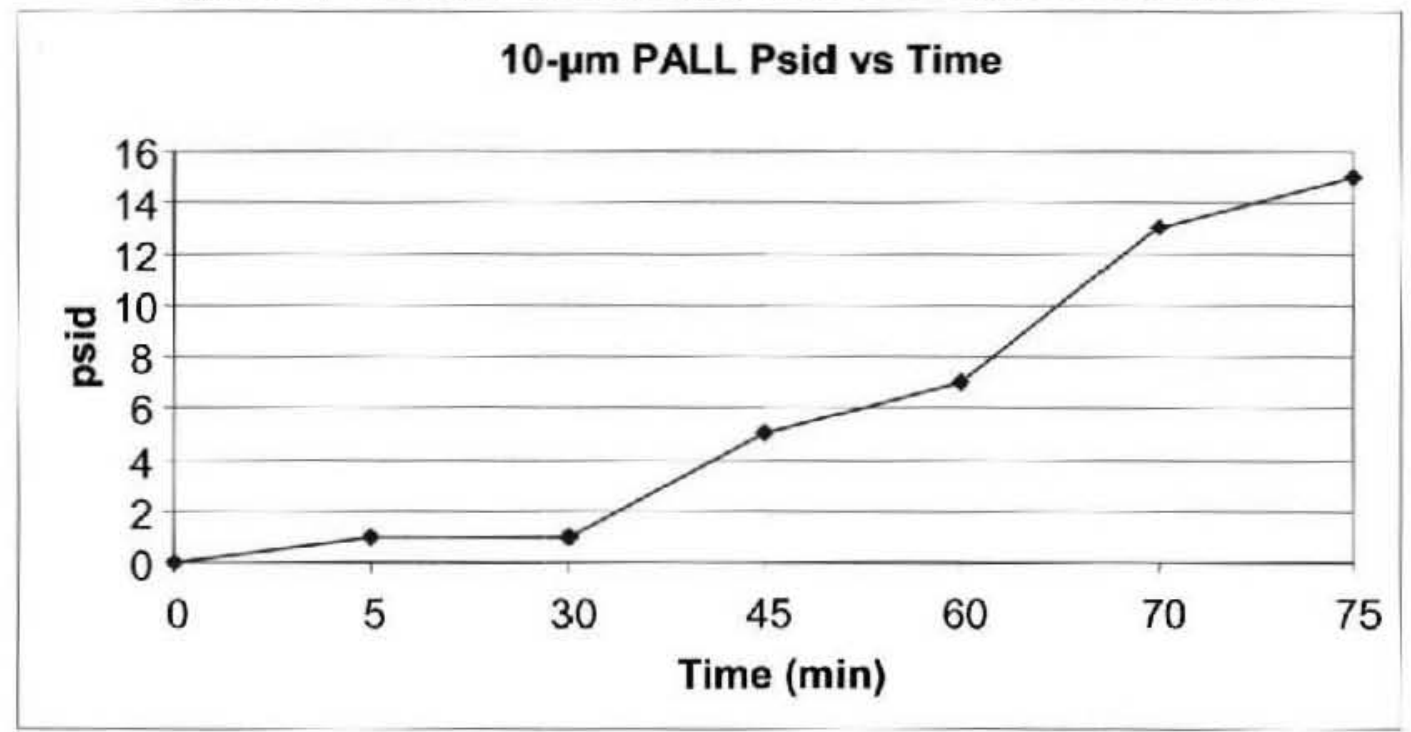

Tables 6 and 7 show the radionuclides retained on the 10- $\mu \mathrm{m}$ Keystone and PALL glass fiber filters. To conserve budget, the inductively coupled plasma-mass spectroscopy was not carried out on these filters. Also, because these are glass fiber composition, it would be expected that there would be a similar response to $\mathrm{KE}$ Basin challenge as exhibited by the $5--\mu \mathrm{m}$ glass fiber filters; also the filters will be replaced on a delta psid of 15 or a radionuclide threshold.

Table 6. Radionuclides Retained on the $10-\mu \mathrm{m}$ Keystone Filter.

\begin{tabular}{|c|c|c|c|c|c|}
\hline \multicolumn{4}{|c|}{ Influent } & \multicolumn{2}{|c|}{ Filter } \\
\hline KE Composite & $\begin{array}{c}\mu \mathrm{Ci} / \mathrm{mL} \\
\text { (8.4 L Total) }\end{array}$ & $\begin{array}{l}\text { Total through } \\
\text { Filter }(\mu \mathrm{C} i)\end{array}$ & $\begin{array}{l}\text { Total through } \\
\text { Filter }(\mathbf{g})^{a}\end{array}$ & $\mu \mathrm{Ci} /$ Filter & $\begin{array}{c}\text { Total on Filter } \\
\text { (g) }\end{array}$ \\
\hline${ }^{60} \mathrm{Co}$ & $5.23 \mathrm{E}-07$ & $4.39 \mathrm{E}-03$ & $3,99 \mathrm{E}-12$ & 6.99E-03 & $6.35 \mathrm{E}-12$ \\
\hline${ }^{137} \mathrm{Cs}$ & $6.96 \mathrm{E}-04$ & 5.85 & $5.97 \mathrm{E}-08$ & 2.99 & $3.05 \mathrm{E}-08$ \\
\hline${ }^{152} \mathrm{Eu}$ & ND & ND & ND & ND & ND \\
\hline${ }^{154} \mathrm{Eu}$ & $7.03 \mathrm{E}-06$ & $5.91 \mathrm{E}-02$ & $3.94 \mathrm{E}-10$ & $6.42 \mathrm{E}-02$ & $4.28 \mathrm{E}-10$ \\
\hline${ }^{155} \mathrm{Eu}$ & ND & ND & ND & $1.38 \mathrm{E}-02$ & $9.86 \mathrm{E}-12$ \\
\hline${ }^{241} \mathrm{Am}$ & $1.26 \mathrm{E}-04$ & 1.06 & $3.31 \mathrm{E}-07$ & 1.14 & $3.56 \mathrm{E}-07$ \\
\hline Total alpha & $1.8 \mathrm{E}-04$ & $1.55^{b}$ & & $2.21^{c}$ & \\
\hline
\end{tabular}

${ }^{4}$ Estimated using spccific activity for the radionuclide of interest.

b A spike was not run therefore the discrepancy could be due to self adsorption on the counting dish due to dissolved solids. A larger sample volume was needed which contained more dissolved solids; this would lead to lower counts due to solids concentration that would adsorb the alpha energy shielding it from the counter.

'The dissolved filter required a smaller sample volume and therefore less solids on the counting dish and a more accurate count. 


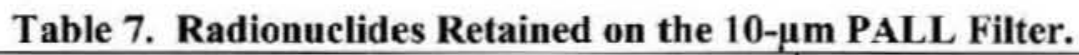

\begin{tabular}{|l|c|c|c|c|c|}
\hline \multicolumn{5}{|c|}{ Influent } & \multicolumn{2}{c|}{ Filter } \\
\hline KE Composite & $\begin{array}{c}\boldsymbol{\mu} \mathbf{C i} / \mathbf{m L} \\
(\mathbf{7 . 9} \mathbf{~ L} \text { Total) }\end{array}$ & $\begin{array}{c}\text { Total through } \\
\text { Filter }(\boldsymbol{\mu C} \mathbf{)})\end{array}$ & $\begin{array}{c}\text { Total through } \\
\text { Filter }(\mathbf{g})^{\mathbf{a}}\end{array}$ & $\boldsymbol{\mu \text { Ci/Filter }}$ & $\begin{array}{c}\text { Total on Filter } \\
(\mathbf{g})\end{array}$ \\
\hline${ }^{61} \mathrm{Co}$ & $5.23 \mathrm{E}-07$ & $4.1 \mathrm{E}-03$ & $3.76 \mathrm{E}-12$ & $1.34 \mathrm{E}-02$ & $1.22 \mathrm{E}-11$ \\
\hline${ }^{137} \mathrm{Cs}$ & $6.96 \mathrm{E}-04$ & 5.5 & $5.61 \mathrm{E}-08$ & 6.24 & $6.38 \mathrm{E}-08$ \\
\hline${ }^{152} \mathrm{Eu}$ & ND & ND & ND & ND & ND \\
\hline${ }^{154} \mathrm{Eu}$ & $7.03 \mathrm{E}-06$ & $5.55 \mathrm{E}-02$ & $3.70 \mathrm{E}-10$ & $1.2 \mathrm{E}-01$ & $8.07 \mathrm{E}-10$ \\
\hline${ }^{155} \mathrm{Eu}$ & ND & ND & ND & $2.77 \mathrm{E}-02$ & $1.98 \mathrm{E}-11$ \\
\hline${ }^{241} \mathrm{Am}$ & $1.26 \mathrm{E}-04$ & $9.95 \mathrm{E}-01$ & $3.11 \mathrm{E}-07$ & 2.43 & $7.59 \mathrm{E}-07$ \\
\hline Total alpha & $1.8 \mathrm{E}-04$ & $1.55^{\mathrm{b}}$ & & $4.23^{\mathrm{c}}$ & \\
\hline
\end{tabular}

${ }^{2}$ Estimaled using specific activity for the radionuclide of interest,

${ }^{b}$ A spike was not run therefore the discrepancy could be due to self adsorption on the counting dish due to dissolved solids. A larger sample volume was needed which contained more dissolved solids; this would lead to lower counts due to solids concentration that would adsorb the alpha energy shielding it from the counter.

${ }^{c}$ The dissolved filter required a smaller sample volume and therefore less solids on the counting dish and a more accurate count.

Figures 22 and 23 show the influent and effluent PSD for the $10-\mu \mathrm{m}$ Keystone Filter. Figure 24 shows the influent PSD for the PALL 10- $\mu \mathrm{m}$ filter. The PALL $10-\mu \mathrm{m}$ filter effluent did not contain enough particle concentration to determine a PSD by the particle size analyzer. The $\mathrm{P}: \mathrm{SD}$ report is contained in its entirety in Appendix F.

Figure 22. Volume-based Particle Size Distributions of KE-Basin Water Influent to the $10-\mu \mathrm{m}$ Keystone Filter.

(Average of duplicate measurements)

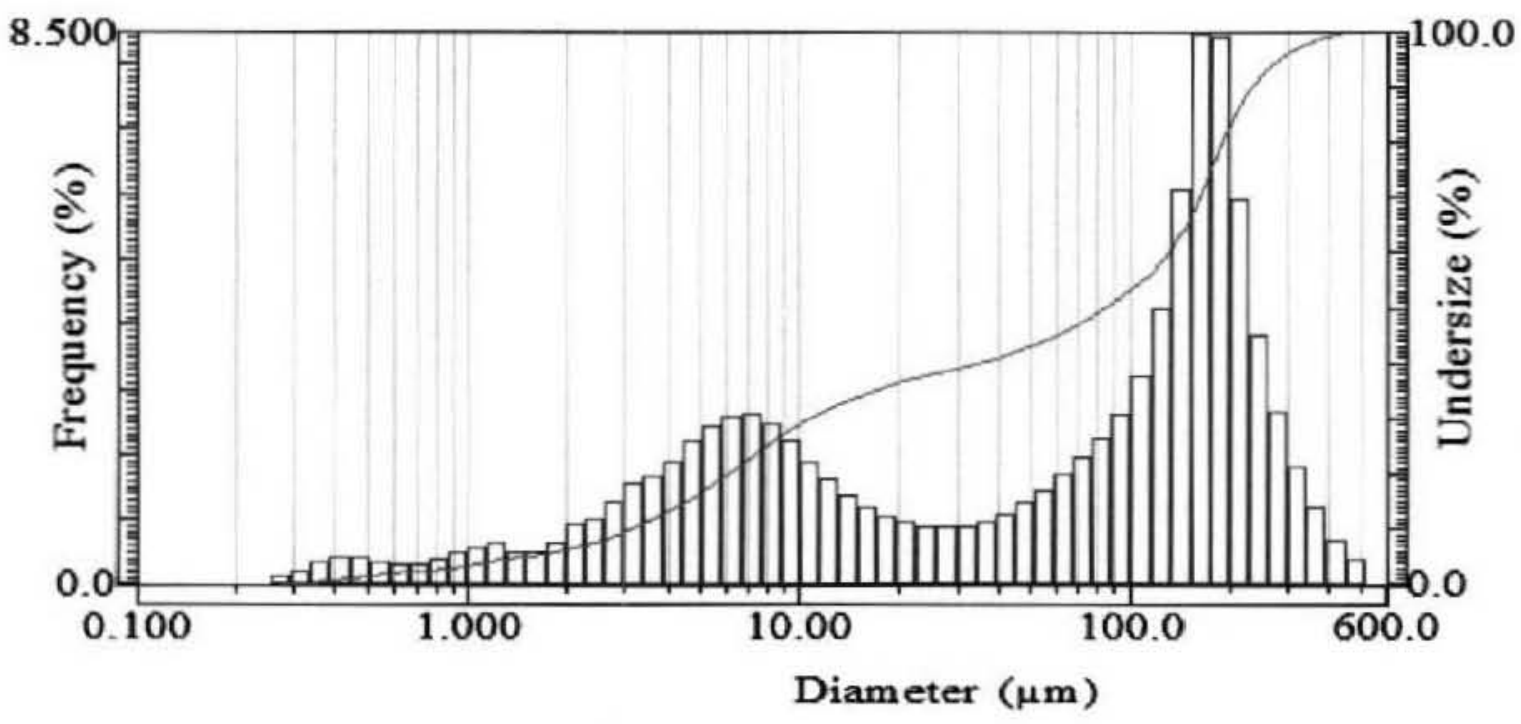


Figure 23. Volume-based Particle Size Distributions of 10 um Keystone Filtrate.

(Average of duplicate measurements)

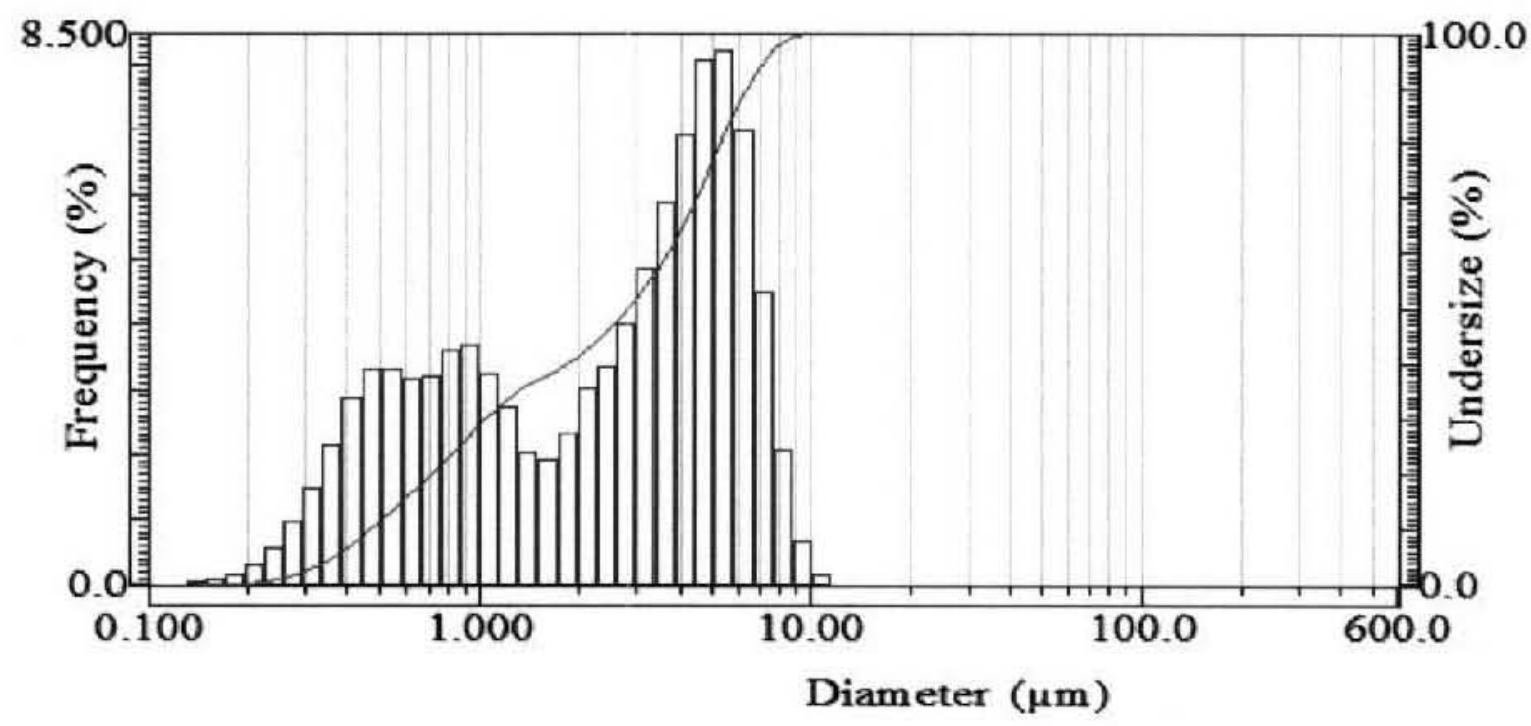

Figure 24. Volume-based Particle Size Distributions of KE-Basin Water Influent to the 10$\mu \mathrm{m}$ PALL Filter.

(Average of duplicate measurements.)

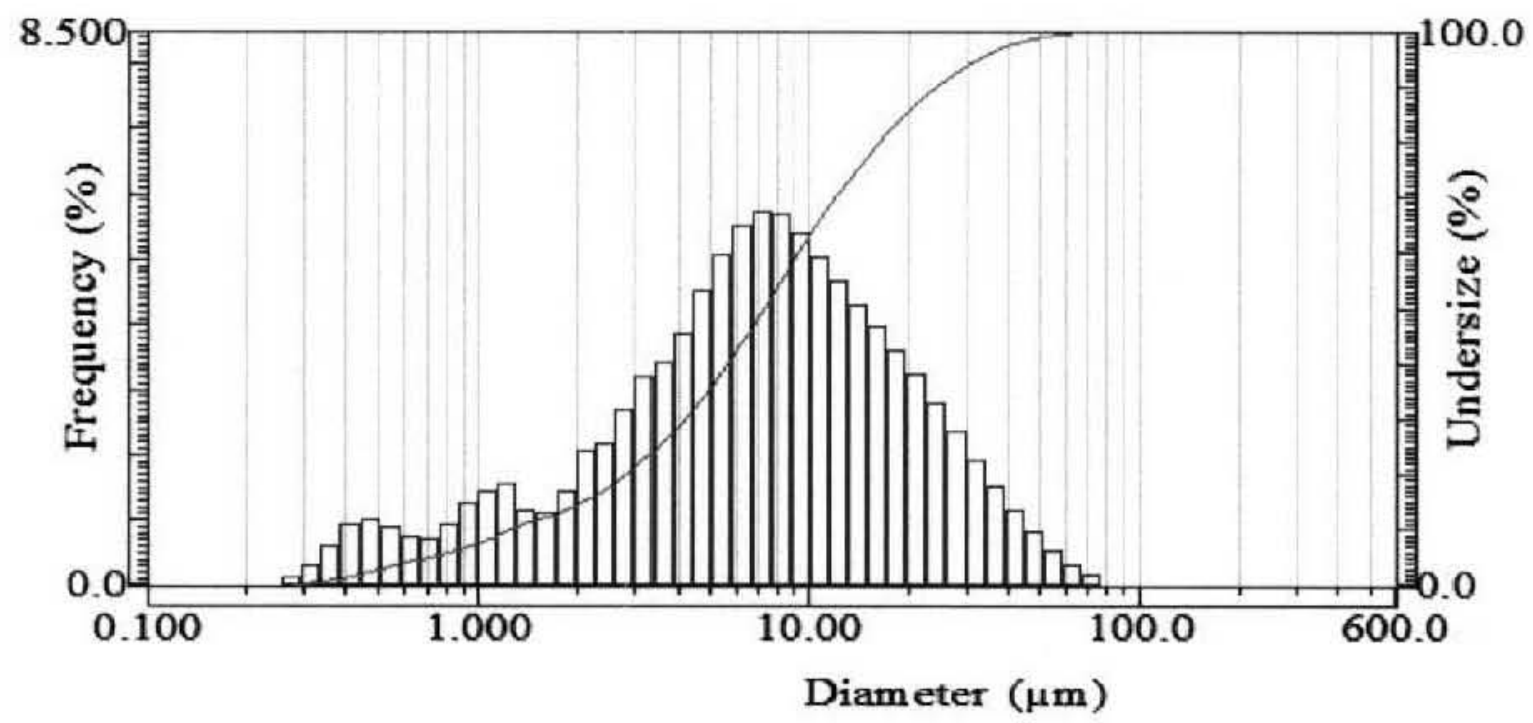

Tables 8 and 9 indicate the parameters associated with the 10- $\mu \mathrm{m}$ Keystone and PALL filters. The radionuclide data was extrapolated using the filter analyses after filtration; see note (a) in Tables 8 and 9. The table attempts to show the microcuries that are captured by the filter during the course of filtration. The filter runs for both the Keystone and PALL were limited to approximately $8 \mathrm{~L}$ each contained in two $1-\mathrm{L}$ carboys. The $10-\mu \mathrm{m}$ Keystone did not achieve a psid of 15 during the run. This is most likely due to the low NTU [and hence low total 
suspended solids (TSS)] contained in the influent. The 10- $\mu \mathrm{m}$ PALL filter was challenged with a much higher NTU (high TSS) and did achieve a psid of 15 before the sample was depleted.

Assuming linearity, a filter surface area of $64 \mathrm{ft}$, and a flow rate of $2 \mathrm{gpm}$, Tables 10 and 11 indicate the relationship of radionuclide to TSS over time and radionuclide capture over time. Tables 12 and 13 are estimates of radionuclide loadings that would occur during filtration at $2 \mathrm{gpm} / \mathrm{ft}^{2}$ or $128 \mathrm{gpm}$. Although Tables 12 and 13 are based on a flow of $2 \mathrm{gpm} / \mathrm{ft}^{2}$, it is probable that lower flow rates would allow a lower rate of loading and more run time. The filters have not been tested in the geometric configuration as supplied by a vendor. Therefore, Tables 12 and 13 are merely an estimate based on filter analysis of the $10-\mu \mathrm{m}$ Keystone and PALL glass fiber filters. As noted, the Keystone did not achieve a psid of 15 due to the low TSS load of the challenge. Therefore it is difficult to predict the amount of run time that would occur in basin conditions at this TSS load. Regardless of the loading by the TSS, it is expected that the filter changeout will not be predicated on psid but rather on the energetics from the captured radionuclides. From these tables, a MicroShield ${ }^{209}$ analysis should be carried out using the geometry and materials of construction for the filter as well as the materials of construction of the filter containers.

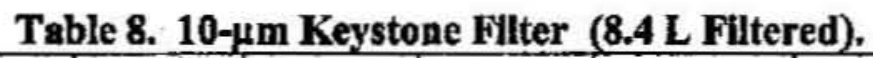

\begin{tabular}{|c|c|c|c|c|c|c|c|}
\hline Time, $T(\min )$ & $\begin{array}{c}0 \\
\text { (initial } \\
\text { value) }\end{array}$ & 3 & 30 & $\because z$ & 60 & 75 & 80 \\
\hline Psid & 0 & 1 & 2 & 3 & 3 & 3 & 3 \\
\hline Infhent NTU & \multicolumn{7}{|c|}{$8(3.6 \mathrm{mg} / \mathrm{L}$ TSS $)$} \\
\hline Effluent NTU & NA & 0.5 & 0.7 & 0.7 & 0.7 & 0.5 & 0.5 \\
\hline $\begin{array}{l}\text { TSS, mg/L at } \\
\text { each T retained } \\
\text { on filter }\end{array}$ & $\overline{\text { NA }}$ & 3.4 & 6.7 & 10.1 & 13.3 & 16.7 & 20.1 \\
\hline \multicolumn{8}{|c|}{ Radionuclides $(\mu \mathrm{Ci} \text { on filter at Time }=\mathrm{T})^{2}$} \\
\hline${ }^{60} \mathrm{Co}$ & - & $4.37 \mathrm{E}-04$ & 2.62E-03 & $3.93 \mathrm{E}-03$ & $5.24 \mathrm{E}-03$ & $6.55 \mathrm{E}-03$ & $6.99 \mathrm{E}-03$ \\
\hline${ }^{137} \mathrm{Cs}$ & - & $1.87 \mathrm{E}-0 \mathrm{I}$ & 1.12 & 1.68 & 2.24 & 2.80 & 2.99 \\
\hline${ }^{152} \mathrm{Eu}$ & - & ND & ND & ND & ND & ND & ND \\
\hline${ }^{154} \mathrm{Eu}$ & - & $4.01 \mathrm{E}-03$ & $2.41 \mathrm{E}-02$ & $3.61 \mathrm{E}-02$ & $4.82 \mathrm{E}-02$ & $6.02 \mathrm{E}-02$ & $6.42 \mathrm{E}-02$ \\
\hline${ }^{155} \mathrm{Eu}$ & - & $8.63 \mathrm{E}-04$ & $5.18 \mathrm{E}-03$ & $7.76 \mathrm{E}-03$ & $1.04 \mathrm{E}-02$ & $1.29 \mathrm{E}-02$ & $1.38 \mathrm{E}-02$ \\
\hline${ }^{241} \mathrm{Am}$ & - & $7.13 \mathrm{E}-02$ & $4.28 \mathrm{E}-01$ & $6.41 \mathrm{E}-01$ & $8.55 \mathrm{E}-01$ & 1.07 & 1.14 \\
\hline Total alpha & - & $1.38 \mathrm{E}-01$ & $8.29 \mathrm{E}-01$ & $1.24 \mathrm{E}$ & 1.66 & 2.07 & 2.21 \\
\hline
\end{tabular}

Because the filter was analyzed at the end of the run, the values during the filter run assume the radionuclide distribution to be nomally and independently distributed. For the europium, a nondetect in the composite sample but accumulated on the filter, the concentration is based on the filter analysis as a function of volumetric throughput.

\footnotetext{
${ }^{9}$ MicroShield is a registered trademark of Grove Software, Inc., Lynchburg, Virginia.
} 
Table 9. 10- $\mu \mathrm{m}$ PALL Filter (7.9 L Filtered).

\begin{tabular}{|c|c|c|c|c|c|c|c|}
\hline Time, $\mathbf{T}$ (min) & $\begin{array}{l}\text { (initial } \\
\text { value) }\end{array}$ & 5 & 30 & 45 & 60 & $r 0$ & 75 \\
\hline Psid & 0 & 1 & 1 & 5 & 7 & 13 & 15 \\
\hline Influent NTU & \multicolumn{7}{|c|}{$23.9(9.5)$} \\
\hline Effluent NTU & NA & 0.16 & 0.08 & 0.09 & 0.06 & 0.34 & - \\
\hline $\begin{array}{l}\mathrm{TSS}, \mathrm{mg} / \mathrm{L} \text { at } \\
\text { each } \mathrm{T} \text { retained } \\
\text { on filter }\end{array}$ & NA & 9.5 & 19 & 28.5 & 38 & 47.4 & 56.8 \\
\hline \multicolumn{8}{|c|}{ Radionuclides $(\mu \mathrm{Ci} \text { on filter at Time }=\mathrm{T})^{\prime}$} \\
\hline${ }^{60} \mathrm{Co}$ & - & 8.93E-04 & $5.36 \mathrm{E}-03$ & $8.04 \mathrm{E}-0.3$ & $1.07 \mathrm{E}-02$ & $1.25 \mathrm{E}-02$ & $1.34 \mathrm{E}-02$ \\
\hline${ }^{137} \mathrm{Cs}$ & - & 4.17E-01 & 2.50 & 3.75 & 5.0 & 5.83 & 6.25 \\
\hline${ }^{152} \mathrm{Eu}$ & $\underline{-}$ & $\mathrm{ND}$ & $\mathrm{ND}$ & ND & $\mathrm{ND}$ & ND & ND \\
\hline${ }^{154} \mathrm{Eu}$ & 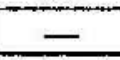 & 8.07E-03 & $4.84 \mathrm{E}-02$ & $7.26 \mathrm{E}-02$ & $9.68 \mathrm{E}-02$ & $1.13 \mathrm{E}-01$ & $1.21 \mathrm{E}-01$ \\
\hline${ }^{155} \mathrm{Eu}$ & - & $1.85 \mathrm{E}-03$ & $1.11 \mathrm{E}-02$ & $1.66 \mathrm{E}-02$ & $2,22 \mathrm{E}-02$ & $2.59 \mathrm{E}-02$ & 2.77 \\
\hline${ }^{241} \mathrm{Am}$ & 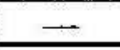 & $1.62 \mathrm{E}-01$ & $9.72 \mathrm{E}-01$ & 1.46 & 1.94 & 2.27 & 2.43 \\
\hline Total alpha & - & 2.82E-01 & 1.69 & 2.54 & 3.38 & 3.95 & 4.23 \\
\hline
\end{tabular}

Since the filter was analyzed at the end of the nu, the values during the filter run assume the raxtionuclide distribution to be nomally and independently distributed. For the europium, a nondetect in the composite sample but accumulated on the filter, the concentration is based on the filter analysis as a function of volumetric throughput.

Table 10. Ratio of Radionuclide to Total Suspended Solids 10 $-\mu \mathrm{m}$ Keystone Filter $(\mu \mathrm{Ci} / \mathrm{TSS} \mathrm{mg} / \mathrm{L})$.

\begin{tabular}{|l|c|c|c|c|c|c|c|c|}
\hline Radionuclide & $\begin{array}{c}\text { Time } \\
(\mathrm{min})\end{array}$ & 0 & 5 & 30 & 45 & 60 & 75 & 80 \\
\hline${ }^{60} \mathrm{Co}$ & & & $1.30 \mathrm{E}-04$ & $3.94 \mathrm{E}-04$ & $3.91 \mathrm{E}-04$ & $3.93 \mathrm{E}-04$ & $3.93 \mathrm{E}-04$ & $3.49 \mathrm{E}-04$ \\
\hline${ }^{137} \mathrm{Cs}$ & & & $5.56 \mathrm{E}-02$ & $1.69 \mathrm{E}-01$ & $1.67 \mathrm{E}-01$ & $1.68 \mathrm{E}-01$ & $1.68 \mathrm{E}-01$ & $1.49 \mathrm{E}-01$ \\
\hline${ }^{153} \mathrm{Eu}$ & & & & & & & & \\
\hline${ }^{154} \mathrm{Eu}$ & & & $1.19 \mathrm{E}-03$ & $3.62 \mathrm{E}-03$ & $3.59 \mathrm{E}-03$ & $3.61 \mathrm{E}-03$ & $3.61 \mathrm{E}-03$ & $3.20 \mathrm{E}-03$ \\
\hline${ }^{155} \mathrm{Eu}$ & & & & & & & & \\
\hline${ }^{241} \mathrm{Am}$ & & & $2.12 \mathrm{E}-02$ & $6.43 \mathrm{E}-02$ & $6.38 \mathrm{E}-02$ & $6.41 \mathrm{E}-02$ & $6.40 \mathrm{E}-02$ & $5.68 \mathrm{E}-02$ \\
\hline Total alpha & & & $4.11 \mathrm{E}-02$ & $1.25 \mathrm{E}-01$ & $1.24 \mathrm{E}-01$ & $1.24 \mathrm{E}-01$ & $1.24 \mathrm{E}-01$ & $1.10 \mathrm{E}-01$ \\
\hline
\end{tabular}

Table 11. Ratio of Radionuclide to Total Suspended Solids 10- $\mu \mathrm{m}$ PALL Filter (

\begin{tabular}{|c|c|c|c|c|c|c|c|}
\hline Badlonuclide & $\begin{array}{l}\text { Time } \\
\text { (min) }\end{array}$ & 0 & $\begin{array}{r}5 \\
\end{array}$ & $\quad 30$ & 45 & 60 & 75 \\
\hline${ }^{60} \mathrm{Co}$ & & 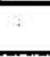 & $9.44 \mathrm{E}-05$ & $5.66 \mathrm{E}-04$ & $2.83 E-04$ & $2.82 \mathrm{E}-04$ & $2.36 \mathrm{E}-04$ \\
\hline${ }^{137} \mathrm{C}$ & & & $1.24 \mathrm{E}-01$ & $2.64 \mathrm{E}-01$ & $1.32 \mathrm{E}-01$ & $1.32 \mathrm{E}-0 \mathrm{t}$ & $1.10 \mathrm{E}-01$ \\
\hline${ }^{152} \mathrm{E}$ & & & & & & & \\
\hline${ }^{154} E$ & & & 2.40E-03 & $5.11 \mathrm{E}-03$ & $2.55 \mathrm{E}-03$ & $2.55 \mathrm{E}-03$ & $2.13 \mathrm{E}-03$ \\
\hline${ }^{155} \mathrm{E}$ & & & & 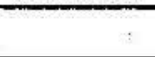 & & & \\
\hline${ }^{241} \mathrm{~A}$ & & & 4.82E- 02 & $1.03 \mathrm{E}-01$ & $5.12 \mathrm{E}-02$ & $5.12 \mathrm{E}-02$ & $4.28 \mathrm{E}-02$ \\
\hline Total alpha & & & $8.39 \mathrm{E}-02$ & $8.92 \mathrm{E}-02$ & $8.92 \mathrm{E}-02$ & 8.91E-02 & $7.45 \mathrm{E}-02$ \\
\hline
\end{tabular}


Table 12. Estimated Radionuclide Loading in $\mu \mathrm{Ci}$ on a Commercial Keystone 10- $\mu \mathrm{m}$ Filter at Indicated Time.

\begin{tabular}{|l|l|l|l|l|l|l|}
\hline \multicolumn{3}{|c|}{} & Flow $=128 \mathrm{gpm}$ & \multicolumn{3}{l|}{ Volume Prosesed 7891 gallons } \\
\hline Radionuclide & $\mathbf{5}(\mathrm{min})$ & $30(\mathrm{~min})$ & $45(\mathrm{mln})$ & $60(\mathrm{~min})$ & $75(\mathrm{mln})$ & $80(\mathrm{~min})$ \\
\hline${ }^{60} \mathrm{Co}$ & 1.52 & 9.12 & $1.37 \mathrm{E}+01$ & $1.82 \mathrm{E}+01$ & $2.28 \mathrm{E}+01$ & $2.43 \mathrm{E}+01$ \\
\hline${ }^{137} \mathrm{Cs}$ & $6.64 \mathrm{E}+02$ & $3.99 \mathrm{E}+03$ & $5.98 \mathrm{E}+03$ & $7.97 \mathrm{E}+03$ & $9.97 \mathrm{E}+03$ & $1.06 \mathrm{E}+04$ \\
\hline${ }^{152} \mathrm{Eu}$ & ND & ND & ND & ND & ND & ND \\
\hline${ }^{154} \mathrm{Eu}$ & $1.43 \mathrm{E}+01$ & $8.57 \mathrm{E}+01$ & $1.29 \mathrm{E}+02$ & $1.71 \mathrm{E}+02$ & $2.14 \mathrm{E}+02$ & $2.28 \mathrm{E}+02$ \\
\hline${ }^{155} \mathrm{Eu}$ & 3.08 & $1.85 \mathrm{E}+01$ & $2.77 \mathrm{E}+01$ & $3.70 \mathrm{E}+01$ & $4.62 \mathrm{E}+01$ & $4.93 \mathrm{E}+01$ \\
\hline${ }^{241} \mathrm{Am}$ & $2.53 \mathrm{E}+02$ & $1.52 \mathrm{E}+03$ & $2.28 \mathrm{E}+03$ & $3.04 \mathrm{E}+03$ & $3.8 \mathrm{E}+03$ & $4.05 \mathrm{E}+03$ \\
\hline Total alpha & $4.91 \mathrm{E}+02$ & $2.95 \mathrm{E}+03$ & $4.42 \mathrm{E}+03$ & $5.89 \mathrm{E}+03$ & $7.37 \mathrm{E}+03$ & $7.86 \mathrm{E}+03$ \\
\hline
\end{tabular}

Table 13. Estimated Radionuclide Loading in $\mu \mathrm{Ci}$ on a Commercial PALL 10- $\mu \mathrm{m}$ Filter at Indicated Time.

\begin{tabular}{|c|c|c|c|c|c|}
\hline$\ldots$ & $\cdots$ & Flow $=12$ & & Volume p & ed 7421 gallons \\
\hline Radionuclide & $5(\min )$ & 30 (min) & $45(\mathrm{~min})$ & 60 (min) & 75 (min) \\
\hline${ }^{60} \mathrm{Co}$ & 3.17 & $1.90 \mathrm{E}+01$ & $2.86 \mathrm{E}+01$ & $3.81 \mathrm{E}+01$ & $4.76 \mathrm{E}+01$ \\
\hline${ }^{137} \mathrm{Cs}_{s}$ & $1.48 \mathrm{E}+03$ & $8.87 \mathrm{E}+03$ & $8.45 \mathrm{E}+03$ & $1.77 \mathrm{E}+04$ & $2.22 E+04$ \\
\hline${ }^{152} \mathrm{Eu}$ & ND & ND & ND & ND & ND \\
\hline${ }^{154} \mathrm{Eu}$ & $2.85 \mathrm{E}+0 \mathrm{I}$ & $1.71 \mathrm{E}+02$ & $2.56 \mathrm{E}+02$ & $3.42 \mathrm{E}+02$ & $4.27 \mathrm{E}+02$ \\
\hline${ }^{155} \mathrm{Eu}$ & 6.57 & $3.94 \mathrm{E}+01$ & $5.92 \mathrm{E}+01$ & $7.89 \mathrm{E}+01$ & $9.86 \mathrm{E}+01$ \\
\hline${ }^{241} \mathrm{Am}$ & $5.76 \mathrm{E}+02$ & $3.46 \mathrm{E}+03$ & $5.18 \mathrm{E}+03$ & $6.19 \mathrm{E}+03$ & $8.64 \mathrm{E}+03$ \\
\hline Total alpha & $1.00 \mathrm{E}+03$ & $6.02 E+03$ & $9.02 \mathrm{E}+03$ & $1.20 \mathrm{E}+04$ & $1.50 \mathrm{E}+04$ \\
\hline
\end{tabular}

\section{CONCLUSIONS AND RECOMMENDATIONS}

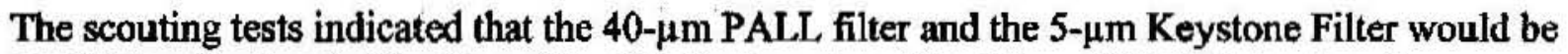
candidates for the clarification of the KE Basin water. The 40- $\mu \mathrm{m}$ PALL did not perform as originally expected. There are several possible reasons for this to have occurred. The flat sheet membranes are usually not homogeneous. The response (effluent) of a commercially configured filter is an average of its capability to a handle challenge (influent). Therefore, the original scouting test selection could have been taken from a "better" part of the flat sheet. Secondly, the scouting tests were conducted under vacuum where the water was puiled rather than pushed through the filter. This media formula may be rated under pressure versus vacuum because vacuum has a tendency to compress the filter media thus yielding a particle size cut off much lower than the manufacturer's claim. Thirdly, there were two different samples of KE Basin used as a challenge. The first was a center of basin that was used as a challenge for the scouting tests. The long-term tests used KE Basin water collected from the sludge container effluent. There is a possibility that the composition was different enough that in the long-term tests, the dissolved solids overwhelmed the zeta plus sites on the filter.

The 5 - $\mu \mathrm{m}$ Keystone Filter performed extremely well. The effluent was below 1 NTU during the course of the run. It was determined that $10-\mu \mathrm{m}$ glass fiber filters from both Keystone and 
PALL should be challenged with KE Basin water to determine efficacy of volume throughput and radionuclide capture. It should be remembered that tap water is less than 1 NTU and is of good clarity.

Table 14 presents the radionuclides captured by the filters as a function of the input.

Table 14. Radionuclide Capture as a Fraction of Input.

\begin{tabular}{|c|c|c|c|}
\hline Radionuclide & Infuent (g) & Effluent (g) & Capture (\%) \\
\hline$+\quad \therefore$ & $40-1$ & PALL & $\therefore$ \\
\hline${ }^{60} \mathrm{Co}$ & $3.99 \mathrm{E}-12$ & $5.13 \mathrm{E}-12^{\mathrm{a}}$ & 129 \\
\hline${ }^{137} \mathrm{Cs}$ & $5.97 \mathrm{E}-08$ & $2.18 \mathrm{E}-08$ & 63.5 \\
\hline${ }^{152} \mathrm{Eu}$ & ND & $9.11 \mathrm{E}-12$ & \\
\hline${ }^{154} \mathrm{Eu}$ & $3.94 \mathrm{E}-10$ & $3.79 \mathrm{E}-10$ & 3.8 \\
\hline${ }^{155} \mathrm{Eu}$ & ND & 9.79E-08 & \\
\hline${ }^{241} \mathrm{Am}$ & 3.31E-07 & $3.09 \mathrm{E}-07$ & 6.7 \\
\hline$+2 \quad+2$ & S-1 $1 \mathrm{~m} \mathrm{~K}$ & tone Filter & $\therefore$ \\
\hline${ }^{-60} \mathrm{Co}$ & $2.28 \mathrm{E}-12$ & 2.67E-12 & 117 \\
\hline${ }^{137} \mathrm{Cs}$ & $3.41 \mathrm{E}-08$ & $1.21 \mathrm{E}-08$ & 65 \\
\hline${ }^{152} \mathrm{Eu}$ & ND & $5.10 \mathrm{E}-12$ & \\
\hline${ }^{154} \mathrm{Eu}$ & $2.25 \mathrm{E}-10$ & $1.83 \mathrm{E}-10$ & 19 \\
\hline${ }^{155} \mathrm{En}$ & ND & $4.71 \mathrm{E}-12$ & \\
\hline${ }^{24 !} \mathrm{Am}$ & $1.89 \mathrm{E}-07$ & $1.56 \mathrm{E}-07$ & 17 \\
\hline
\end{tabular}

Table 15 indicates the total alpha captured by each filter as well as the weight of the filter. It can be readily seen that the filters would come under Transuranic (TRU) waste at $>100 \mathrm{nCi} / \mathrm{g}$.

Table 15. Total Alpha Associated with the Filters.

\begin{tabular}{|c|c|c|c|}
\hline Fllter & Total Alpha ( $\mu$ C1/filter) & Filter Welght (g) & $\mu C V_{g}$ \\
\hline 40- $\mu$ m PALL & 2.11 & 0.078 & 27.05 \\
\hline 5- $\mu \mathrm{m}$ Keystone & 1.12 & 0.1808 & 6.19 \\
\hline 10- $\mu$ m Keystane & 2.21 & 0.1805 & 12.24 \\
\hline $10-\mu \mathrm{m}$ PALL & 4.23 & 0.1284 & 32.94 \\
\hline
\end{tabular}

Table 16 presents the analytes retained by the filters.

The filter area is approximately $0.018 \mathrm{ft}^{2}$. Assuming linearity and Gaussian distribution, Table 17 presents assumptions around the filters tested. The $40-\mu \mathrm{m}$ PALL filter did not perform as expected. It should be noted that pleated sheet filters will capture more than a flat sheet test bed. Therefore, the figures given in Table 17 are based on the test bed and not on a final commercially available filter configuration.

The 5- $\mu \mathrm{m}$ and $10-\mu \mathrm{m}$ Keystone and 10- $\mu \mathrm{m}$ PALL filters will give excellent water clarity. Whether or not it is efficacious to the needs of KE Basin remains to be determined based on the 
number of filters employed or disposal path (can the filters be encased in enough grout to be considered non-TRU if needed? Remotely or contact handled?).

Table 16. Analytes Retained on the Filters.

\begin{tabular}{|c|c|c|}
\hline Analyte & 40- $\mu \mathrm{m}$ PALL & 5- $\mu \mathrm{m}$ Keystone \\
\hline$\because$ & $\begin{array}{l}\text { Mass Retalned on the } \\
\text { Filter (mg) }\end{array}$ & $\begin{array}{l}\text { Mass Retained on the } \\
\text { Filter (mg) }\end{array}$ \\
\hline Aluminum & 3,432 & 2,159 \\
\hline Boron & 202 & 93 \\
\hline Calcium & 3,696 & 187 \\
\hline Cadmium & 0 & 16.99 \\
\hline Iron & 9,657 & 5937.94 \\
\hline Potassium & 0 & 1,530 \\
\hline Magnesium & 117 & $-206^{a}$ \\
\hline Sodium & 2,874 & $-2,621^{*}$ \\
\hline Sulfur & 0 & 2,131 \\
\hline Silicon & 2,738 & $-9,115^{*}$ \\
\hline Titanimm & 0 & 37.99 \\
\hline Uranium & 0 & $2,567.85$ \\
\hline Zinc & 41 & 59.98 \\
\hline
\end{tabular}

"Indicates that the 5 - $\mu \mathrm{m}$ filter released magnesium, sodium, and silicon into the effluent. There is that possibility as sodium and silicon are part of the chemical composition of glass. Magnesium could be в part of the manufacturing process of the Keystone glass fiber filters. The carryover of these analytes would probably not have occurred had the filter been subjected to several washings. The manufacturer did not allude to such a step before commencing filtration.

Table 17. Estimated Radionuclide Loading and Volume for a Filter Cartridge of 64 Square Feet. (2 sheets)

\begin{tabular}{|c|c|c|c|}
\hline Radionuclides & $\begin{array}{l}\text { Radionuclldes } \\
\text { Coptured } \\
\text { a18 Ft }{ }^{2} \text { of } \\
\text { Filter }\end{array}$ & $\begin{array}{l}\text { Redionuclides } \\
\text { Captured } \\
\left.\text { (1iCi/n }{ }^{2}\right)\end{array}$ & $\begin{array}{l}\text { Estimated Values } \\
(\mu \mathrm{Cl} / \mathrm{Filter} \text { Cartridge) } \\
\text { of } 64 \mathrm{n}^{2} \text { of Filter } \\
\text { Median }\end{array}$ \\
\hline \multicolumn{4}{|c|}{ 5-um Keystone Glass Flber Filter. } \\
\hline${ }^{60} \mathrm{Co}$ & $2.94 \mathrm{E}-03$ & 0.163 & 10.43 \\
\hline${ }^{137} \mathrm{Cs}$ & 1.19 & 66.11 & $4,231,04$ \\
\hline${ }^{152} \mathrm{Eu}$ & $9.69 \mathrm{E}-04$ & 0.054 & 3.46 \\
\hline${ }^{158} \mathrm{Eu}$ & $2.75 \mathrm{E}-02$ & 1.53 & 97.92 \\
\hline${ }^{153} \mathbf{E u}$ & $6.59 \mathrm{E}-03$ & 0.36 & 23.04 \\
\hline${ }^{211} \mathrm{Am}$ & 0.499 & 27.72 & $1,774.08$ \\
\hline Total alpha & 1.12 & 62.22 & $3,982.08$ \\
\hline $\begin{array}{c}\text { Volume Processed/ } \\
0.018 \mathrm{ft}^{2}\end{array}$ & $\begin{array}{l}\text { Volume (gal) } \\
\text { Processed/ft }\end{array}$ & \multicolumn{2}{|c|}{$\begin{array}{c}\text { Estimated Volume (gai)/64 } \mathrm{ft}^{2} \\
\text { of Fuler Medila }\end{array}$} \\
\hline $1.27 \mathrm{gal}(4.8 \mathrm{~L})$ & 70.6 & & 518.4 \\
\hline \multicolumn{4}{|c|}{ 10- $\mu \mathrm{m}$ Keystone Glass Fiber Filter } \\
\hline${ }^{86} \mathrm{Co}$ & $6.99 \mathrm{E}-03$ & 0.38 & 24.32 \\
\hline${ }^{132} \mathrm{Cs}$ & 2.99 & 166.11 & $10,631.04$ \\
\hline${ }^{152} \mathrm{Eu}$ & ND & ND & ND \\
\hline${ }^{119} \mathrm{Eu}$ & $6.42 \mathrm{E}-02$ & 3.57 & 228.48 \\
\hline
\end{tabular}


Table 17. Estimated Radionuclide Loading and Volume for a Filter Cartridge of 64 Square Feet. (2 sheets)

\begin{tabular}{|c|c|c|c|}
\hline Radionuclides & $\begin{array}{l}\text { Radlonuclides } \\
\text { Captured/ } \\
0.018 \mathrm{Ft}^{2} \text { of } \\
\text { Ellter }\end{array}$ & $\begin{array}{l}\text { Radionuclides } \\
\text { Captured } \\
\left.\text { (uCU/t }{ }^{2}\right)\end{array}$ & 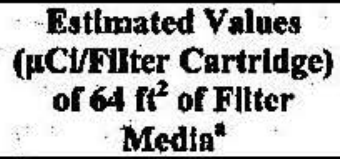 \\
\hline${ }^{135} \mathrm{Eu}$ & $1.38 \mathrm{E}-02$ & 0.77 & 49.28 \\
\hline${ }^{2 \pi} \mathrm{Am}$ & 1.14 & 63.33 & $4,053.12$ \\
\hline Total alpha & 2.21 & 122.78 & $7,857.92$ \\
\hline $\begin{array}{c}\text { Volume processed/ } \\
\text { A.018 } \mathrm{ft}^{2}\end{array}$ & $\begin{array}{l}\text { Volume (gal) } \\
\text { processed/ft }\end{array}$ & \multicolumn{2}{|c|}{$\begin{array}{c}\text { Estlmated Volume (Bal) } / 64 \mathrm{ft}^{2} \text { of fllter } \\
\text { media }\end{array}$} \\
\hline $2.22 \mathrm{gal}(8.4 \mathrm{~L})$ & 123.3 & \multicolumn{2}{|c|}{7,891} \\
\hline \multicolumn{4}{|c|}{ 10-jw PALL Glass Fiber Filter } \\
\hline${ }^{60} \mathrm{Co}$ & $1.34 \mathrm{E}-02$ & 0.744 & 47.62 \\
\hline${ }^{137} \mathrm{Cs}$ & 6.24 & 346.67 & $22,186.9$ \\
\hline${ }^{152} \mathbf{E u}$ & $\mathrm{ND}$ & $\mathrm{ND}$ & ND \\
\hline${ }^{154} \mathrm{Eu}$ & $1.2 \mathrm{E}-01$ & 6.67 & 426.9 \\
\hline${ }^{155} \mathrm{Eu}$ & $2.77 \mathrm{E}-02$ & 1.54 & 98.6 \\
\hline${ }^{211} \mathrm{Am}$ & 2.43 & 135.0 & $8,640,0$ \\
\hline Total alpha & 4.23 & 235.0 & 15,040 \\
\hline $\begin{array}{c}\text { Volame processed/ } \\
0,018 \mathrm{ft}^{2}\end{array}$ & $\begin{array}{l}\text { Volune (gal) } \\
\text { processed/ft }\end{array}$ & \multicolumn{2}{|c|}{$\begin{array}{c}\text { Estimated Volume (gal)/64 } \mathrm{ft}^{2} \text { of filter } \\
\text { media }\end{array}$} \\
\hline $2.08 \mathrm{gal}(7.9 \mathrm{~L})$ & 115.5 & \multicolumn{2}{|c|}{7,421} \\
\hline
\end{tabular}

The 10- $\mu \mathrm{m}$ Keystone filter never reached the delta $\mathrm{P}$ of $15 \mathrm{psi}$. Albeit the challenge turbidities differed, there were more particles in the 100 to $600-\mu \mathrm{m}$-diameter range than were in the challenge to the PALL filter. The PALL filter reached a delta $P$ of 15 after 75 minutes run time with a lower PSD, which may be indicative of more filter changes than Keystone when used with the Tri-Nuc. This will have to be verified with field testing at the pilot or full-scale level.

It is concluded that filtration will affect a positive result in water clarity. The 5 - $\mu \mathrm{m}$ Keystone may be too effective and that level of particulate removal does not need to be achieved. The two candidates for filtration would be the PALL and the Keystone 10- $\mu \mathrm{m}$ filters. As to the best candidate, a MicroShield analysis should be carried out, albeit the ratio of radionuclides to TSS is not that great. It is further recommended that a full-scale test be accomplished in the basin with a set of each manufacturer's filters.

As part of the test, consideration should be given to the volume of water processed, the required clarity of the water, the required total suspended solids of the water, disposal pathways for the filtered material, and the amount of filters consumed. 


\section{RPP-RPT-30093, Rev. 0}

\section{REFERENCES}

CH2M-0403713, 2004, "Measurement of Particle Size Distributions in 105-KE Basin Water" (external letter from W. S. Calloway to R. M. Jochen, December 2), CH2M HILL Hanford Group, Inc., Richland, Washington.

CH2M-0501139 REISSUE, 2005, "Results of Coagulation Processes to Improve Water Clarity at the K East Spent Nuclear Fuel Basin" (external letter from J. B. Duncan to S. P. Burke, April 18), CH2M HILL Hanford Group, Inc., Richland, Washington.

Davies-Colley, R. J., and D. G. Smith, 2001, "Turbidity, Suspended Sediment, and Water Clarity: A Review," Journal of the American Water Resources Association 37(5):1085-1101.

Davies-Colley, R. J., W. N. Vant, and D. G. Smith, 1993, Colour and Clarity of Natural Waters, Ellis Horwood, New York, New York, 310 pp.

Gibbs, R. J., 1978, "Light Scattering From Particles of Different Shapes," Journal of Geophysical Research 83C1:501-502.

H-1-87430, 2003, Drawing KE-Basin STS LDC (LDC SN\#7 \& Greater) Filter Assembly, Fluor Hanford, Richland, Washington.

HNF-SP-1201, 1997, Analysis of Sludge from Hanford $K$ East Basin Canisters, DE\&S Hanford, Inc., Richland, Washington.

KBCP-SRDP-05-MA-UNO6, Evaluate continued use of UCC filters, Issue Identification Form, dated February 4, 2005.

Kirk, J. T. O., 1988, "Optical Water Quality - What Does It Mean and How Should We Measure It?" Journal of the Water Pollution Control Federation 60:194-197.

Kirk, J. T. O., 1985, "Effects of Suspensiods (Turbidity) on Penetration of Solar Radiation in Aquatic Ecosystems," Hydrobiologia 125:195-208.

RPP-PLAN-26932, 2005, Test Plan to Demonstrate Efficacy of Filtration Processes to Obtain Water Clarity at KE Basin, Rev. 0, CH2M HILL Hanford Group, Richland, Washington.

Van de Hulst, H. C., 1957, Light Scattering by Small Particles, John Wiley and Sons, New York, New York, $470 \mathrm{pp}$.

WAC 173-303-040, "Dangerous Waste Regulations," Washington Administrative Code, as amended. 
RPP-RPT-30093, Rev. 0

APPENDIX A

ANALYSES OF KE BASIN COMPOSITE

A-1 
Table A-1. Inductively Coupled Plasma Spectroscopy Analyses of KE Composite (Labcore SO6K000011).

\begin{tabular}{|c|c|c|c|}
\hline Analyte & $\begin{array}{c}\text { Concentration } \\
(\mathrm{kg} / \mathrm{mL})\end{array}$ & Analyte & $\begin{array}{c}\text { Concentration } \\
(\mu \mathrm{g} / \mathrm{mL})\end{array}$ \\
\hline Ag (silver) & $<$ AE $-03^{2}$ & P (phosphorous) & $<4.2 \mathrm{E}-02$ \\
\hline Al (aluminmm) & 0.45 & $\mathrm{~Pb}$ (lead) & $<3.6 \mathrm{E}-02$ \\
\hline As (arsenic) & $<5.2 \mathrm{E}-02$ & Pd (palladium) & $<3.8 \mathrm{E}-02$ \\
\hline B (boron) & $7.34 \mathrm{E}-02$ & Pr (praseodymium) & $<9 \mathrm{E}-03$ \\
\hline Ba (barium) & $<7.3 \mathrm{E}-03$ & $\mathrm{Rb}$ (rubidium) & $<0.514$ \\
\hline Be (beryllium) & $<1.2 \mathrm{E}-03$ & Rh (rhodium) & $<2.6 \mathrm{E}-02$ \\
\hline Bi (bismuth) & $<0.102$ & Ru (ruthenium) & $<1.7 \mathrm{E}-02$ \\
\hline $\mathrm{Ca}$ (calcium) & 0.992 & S (sulfur) & 0.444 \\
\hline Cd (cadmium) & $3.46 \mathrm{E}-03$ & Sb (antimony) & $<2.8 \mathrm{E}-02$ \\
\hline Co (cerium) & $<1.5 \mathrm{E}-02$ & Se (selenium) & $<6.42 \mathrm{E}-02$ \\
\hline Co (cobalt) & $\angle 8 \mathrm{E}-03$ & Si (silicon) & 1.241 \\
\hline Cr (chromium) & $<1.4 \mathrm{E}-02$ & Sm (samarium) & $<1.7 \mathrm{E}-02$ \\
\hline $\mathrm{Cu}$ (copper) & $<1,4 \mathrm{E}-02$ & Sn (tin) & $<3.4 \mathrm{E}-02$ \\
\hline Eu (europinm) & $<1 \mathrm{E}-03$ & Sr (strontium) & $<7 \mathrm{E}-03$ \\
\hline $\mathrm{Fe}$ (iron) & 1.237 & $\mathrm{Ta}$ (tantalum) & $<5.7 \mathrm{E}-02$ \\
\hline $\mathbf{K}$ (potassium) & 0.319 & Te (tellurium) & $<8.4 \mathrm{E}-02$ \\
\hline La (lanthanum) & $\angle 8 \mathrm{E}-03$ & Th (thorium) & $<9 \mathrm{E}-03$ \\
\hline Li(lithium) & $\angle 9 \mathrm{E}-03$ & Ti (titanium) & $7.89 \mathrm{E}-03$ \\
\hline $\mathrm{Mg}$ (magnesium) & $4.58 \mathrm{E}-02$ & T1 (thallium) & $<5.6 \mathrm{E}-02$ \\
\hline Mn (manganese) & $<7 \mathrm{E}-03$ & $\mathrm{U}$ (uranium) & 0.535 \\
\hline Mo (molybdemum) & $<3 \mathrm{E}-03$ & V (yanadium) & $<6 \mathrm{E}-03$ \\
\hline $\mathrm{Na}$ (sodium) & 1.084 & W (fungsten) & $<8.6 \mathrm{E}-02$ \\
\hline $\mathrm{Nd}$ (neodymium) & $<8 \mathrm{E}-03$ & $\mathrm{Y}$ (yttrium) & $<1.1 \mathrm{E}-02$ \\
\hline $\mathrm{Ni}$ (nickel) & $<2.2 \mathrm{E}-02$ & $\operatorname{Zn}$ (zinc) & $1.25 \mathrm{E}-02$ \\
\hline $\mathrm{Nb}$ (niobium) & $<8.4 \mathrm{E}-02$ & $\mathrm{Zr}$ (zirconium) & $<2 \mathrm{E}-02$ \\
\hline
\end{tabular}

"A " $<$ " sign indicated the analyte concentration was below detection limit.

Table A-2. Gamma Energy Analysis KE Composite.

\begin{tabular}{|c|c|}
\hline Analyte & Concentration $(\mu \mathrm{CV} / \mathrm{mL})$ \\
\hline${ }^{60} \mathrm{Co}$ & $5.23 \mathrm{E}-07$ \\
\hline${ }^{137} \mathrm{Cs}$ & $6.96 \mathrm{E}-04$ \\
\hline${ }^{150} \mathrm{Ea}$ & $7.03 \mathrm{E}-06$ \\
\hline${ }^{241} \mathrm{Am}$ & $1.26 \mathrm{E}-04$ \\
\hline
\end{tabular}

NOTE: Reported analytes are above detection limit; below detection limit analytes are not listed.

\section{Table A-3. Total Alpha Analysis KE Composite.}

\begin{tabular}{|c|c|}
\hline Analyte & Concentration $(\mu \mathrm{CV} / \mathrm{mL})$ \\
\hline Total alpha count & $1.84 \mathrm{E}-04$ \\
\hline
\end{tabular}

Table A-4. Total Organic Carbon Analyses KE Composite.

\begin{tabular}{|c|c|}
\hline Analyte & Concentration (eg/mL) \\
\hline Total organic carbon & $\left\langle 5.5^{\mathbf{2}}\right.$ \\
\hline
\end{tabular}

"A " $<$ " sign indicated the analyte concentration was below detection limit. 
RPP-RPT-30093, Rev. 0

APPENDIX B

INITLAL TEST OF 40-MICRON PALL AND 5-MICRON KEYSTONE FILTERS

B-1 
RPP-RPT-30093, Rev. 0

Table B-1. Gamma Energy Analysis of Initial $150 \mathrm{~mL}$ of KE Composite through 40- $\mu \mathrm{m}$ PALL and 5- $\mu \mathrm{m}$ Keystone Filters.

\begin{tabular}{|c|c|c|c|c|c|c|}
\hline \multirow[b]{2}{*}{ Sample } & \multirow[b]{2}{*}{ Radionuclide } & \multirow[b]{2}{*}{$\mu \mathrm{Cl} / \mathrm{m} \mathbf{m}$} & \multirow{2}{*}{$\begin{array}{l}\text { Counting } \\
\text { Error }\end{array}$} & \multicolumn{3}{|c|}{ Total $\mu$ Ci based on Counting Error } \\
\hline & & & & Low & Average & High \\
\hline \multirow[t]{5}{*}{ Composite } & ${ }^{80} \mathrm{Co}$ & $5.23 \mathrm{E}-07$ & 45.48 & $4.28 \mathrm{E}-05$ & $7.85 \mathrm{E}-05$ & $1.14 \mathrm{E}-04$ \\
\hline & ${ }^{37} \mathrm{Cs}$ & $6.96 \mathrm{E}-04$ & 4,27 & $1.00 \mathrm{E}-01$ & $1.04 \mathrm{E}-01$ & $1.09 \mathrm{E}-01$ \\
\hline & ${ }^{554} \mathrm{Eu}$ & $7.03 \mathrm{E}-06$ & 10.65 & $9.42 \mathrm{E}-04$ & $1.05 \mathrm{E}-03$ & $1.17 \mathrm{E}-03$ \\
\hline & ${ }^{153} \mathrm{Eu}$ & $2.62 \mathrm{E}-06$ & NA & & & \\
\hline & ${ }^{2 \pi} \mathrm{Am}$ & $1,26 \mathrm{E}-04$ & 5.44 & $1.79 \mathrm{E}-02$ & $1.89 \mathrm{E}-02$ & $1.99 \mathrm{E}-02$ \\
\hline Filter gnalysis (soHd) & & Cinfriter & & & & \\
\hline \multirow{5}{*}{$40 \mu \mathrm{m}, 0.078 \mathrm{~g}$} & ${ }^{80} \mathrm{Co}$ & $1.71 \mathrm{E}-04$ & 9.72 & $1.54 \mathrm{E}-04$ & $1.07 \mathrm{E}-04$ & $1.88 \mathrm{E}-04$ \\
\hline & ${ }^{137} \mathrm{Cs}$ & $8.06 \mathrm{E}-02$ & 4 & $7.74 \mathrm{E}-02$ & $8.06 \mathrm{E}-02$ & $8.39 \mathrm{E}-02$ \\
\hline & ${ }^{754} \mathrm{Eu}$ & 1.18E-03 & 4.89 & $1.12 \mathrm{E}-03$ & $1.18 \mathrm{E}-03$ & $1.24 \mathrm{E}-03$ \\
\hline & ${ }^{155} \mathrm{Eu}$ & $1.95 \mathrm{SE}-04$ & 40.13 & $1.16 \mathrm{E}-04$ & $1.95 \mathrm{E}-04$ & $2.73 \mathrm{E}-04$ \\
\hline & ${ }^{2 \pi} \mathrm{Am}$ & $2.18 \mathrm{E}-02$ & 5.33 & $2.06 \mathrm{E}-02$ & $2.18 \mathrm{E}-02$ & $2.30 \mathrm{E}-02$ \\
\hline & & & & & & \\
\hline \multirow{5}{*}{$\begin{array}{l}5 \mu \mathrm{m}, 0.1808 \mathrm{~g} \\
\text { following } 40 \mu \mathrm{m}\end{array}$} & ${ }^{80} \mathrm{Co}$ & $<2.23 \mathrm{E}-05$ & NA & & & \\
\hline & ${ }^{137} \mathrm{Cs}$ & $1.07 \mathrm{E}-02$ & 4.12 & $1.02 \mathrm{E}-02$ & $1.07 \mathrm{E}-02$ & $1.11 \mathrm{E}-02$ \\
\hline & ${ }^{\mathbf{T S T}} \mathbf{E u}$ & 2.52E-04 & 8.28 & $2.32 \mathrm{E}-04$ & $2.52 \mathrm{E}-04$ & $2.72 \mathrm{E}-04$ \\
\hline & ${ }^{155} \mathbf{E u}$ & $7.80 \mathrm{E}_{-} 05$ & 34.55 & $5.11 \mathrm{E}-05$ & $7.80 \mathrm{E}-05$ & $1.05 \mathrm{E}-04$ \\
\hline & ${ }^{2 m} \mathrm{Am}$ & $4.99 \mathrm{E}-03$ & 5.47 & $4.72 \mathrm{E}-03$ & $4.99 \mathrm{E}-03$ & $5.26 \mathrm{E}-03$ \\
\hline \multirow{5}{*}{$\begin{array}{l}5-\mu \mathrm{m} \text { filter only, } \\
0.1808 \mathrm{~g}\end{array}$} & ${ }^{80} \mathrm{Co}$ & $2.10 \mathrm{E}-04$ & 9.02 & $1.91 \mathrm{E}-04$ & $2.10 \mathrm{E}-04$ & $2.29 \mathrm{E}-04$ \\
\hline & ${ }^{15} \mathrm{Cs}-$ & $8.73 \mathrm{E}-02$ & 3.99 & $8.38 \mathrm{E}-02$ & $8.73 \mathrm{E}-02$ & $9.08 \mathrm{E}-02$ \\
\hline & ${ }^{15 x} \mathbf{E u}$ & $1.71 \mathrm{E}-03$ & 4.21 & $1.63 \mathrm{E}-03$ & $1.71 \mathrm{E}-03$ & $1.78 \mathrm{E}-03$ \\
\hline & ${ }^{155} \mathbf{E u}$ & 2.88 E-04 & 32.65 & $1.94 \mathrm{E}-04$ & $2.88 \mathrm{E}-04$ & $3.82 \mathrm{E}-04$ \\
\hline & ${ }^{2 m} \mathrm{Am}$ & $3.14 \mathrm{E}-02$ & 5.32 & $2.97 \mathrm{E}-02$ & $3.14 \mathrm{E}-02$ & $3.30 \mathrm{E}-02$ \\
\hline
\end{tabular}

Table B-2. Total Alpha Associated with the 40- $\mu \mathrm{m}$ and 5- $\mu \mathrm{m}$ Filters.

\begin{tabular}{|l|c|c|c|c|}
\hline \multicolumn{1}{|c|}{ Sample } & aC/Futer & Urror & $\mu \mathrm{Cl} / \mathrm{gram}$ & $\mathrm{nCV} / \mathrm{gram}$ \\
\hline $4 \mu \mathrm{m}$ & $2.95 \mathrm{E}-02$ & 1.87 & $3.78 \mathrm{E}-01$ & 378 \\
\hline $5 \mu \mathrm{m}$ after $40 \mu \mathrm{m}$ & $8.96 \mathrm{E}-03$ & 3.41 & $4.96 \mathrm{E}-02$ & 49.6 \\
\hline $5 \mu \mathrm{m}$ & & & & \\
\hline
\end{tabular}


RPP-RPT-30093, Rev. 0

\section{APPENDIX C}

SCOUTING TESTS: CANDIDATE FILTER MEDIA CHALLENGED WITH KE BASIN WATER 
RPP-RPT-30093, Rev. 0

Figure C-1. 40- $\mu \mathrm{m}$ Glass Fiber Filter.

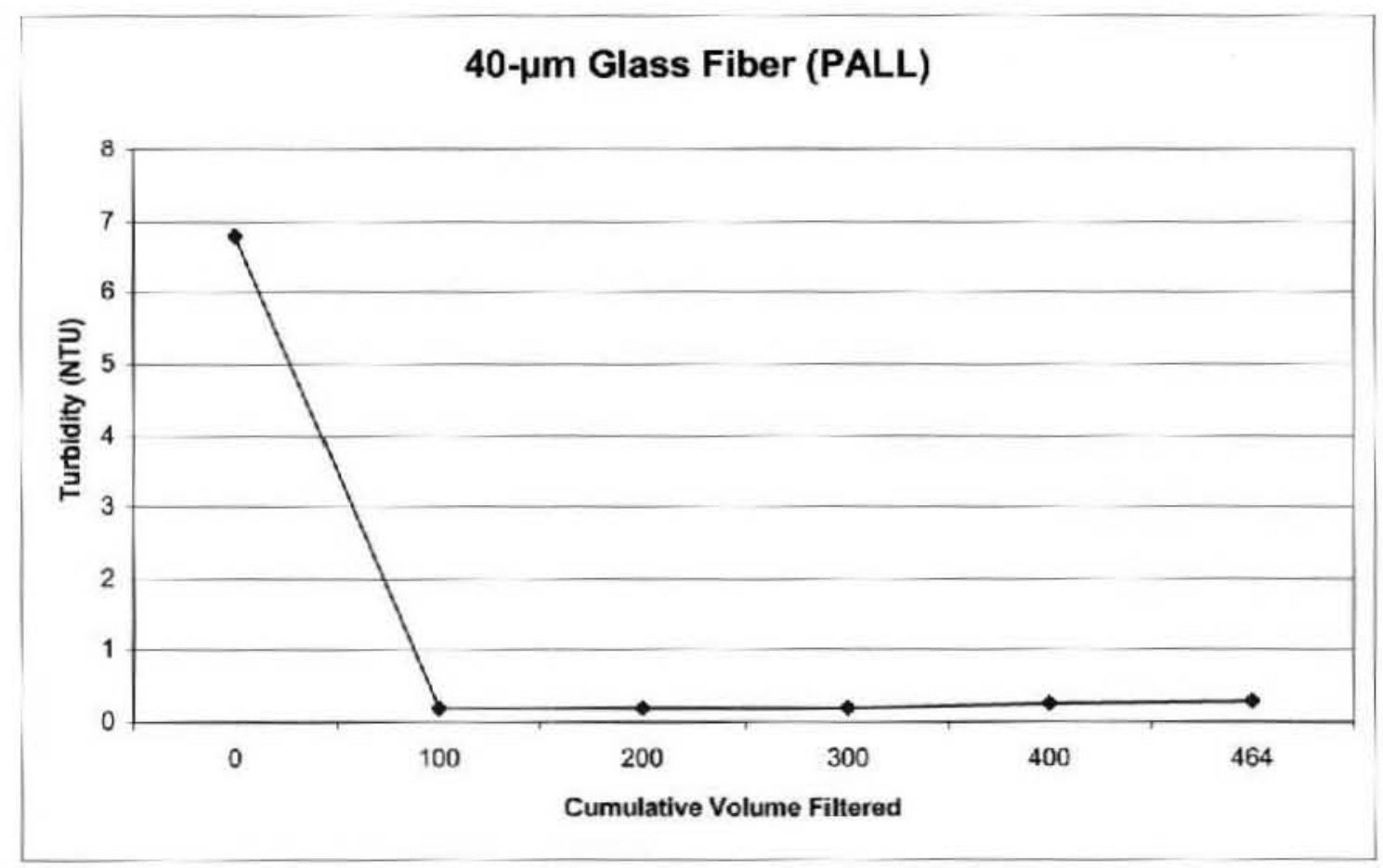

Figure C-2. 20- $\mu \mathrm{m}$ Polyester Filter.

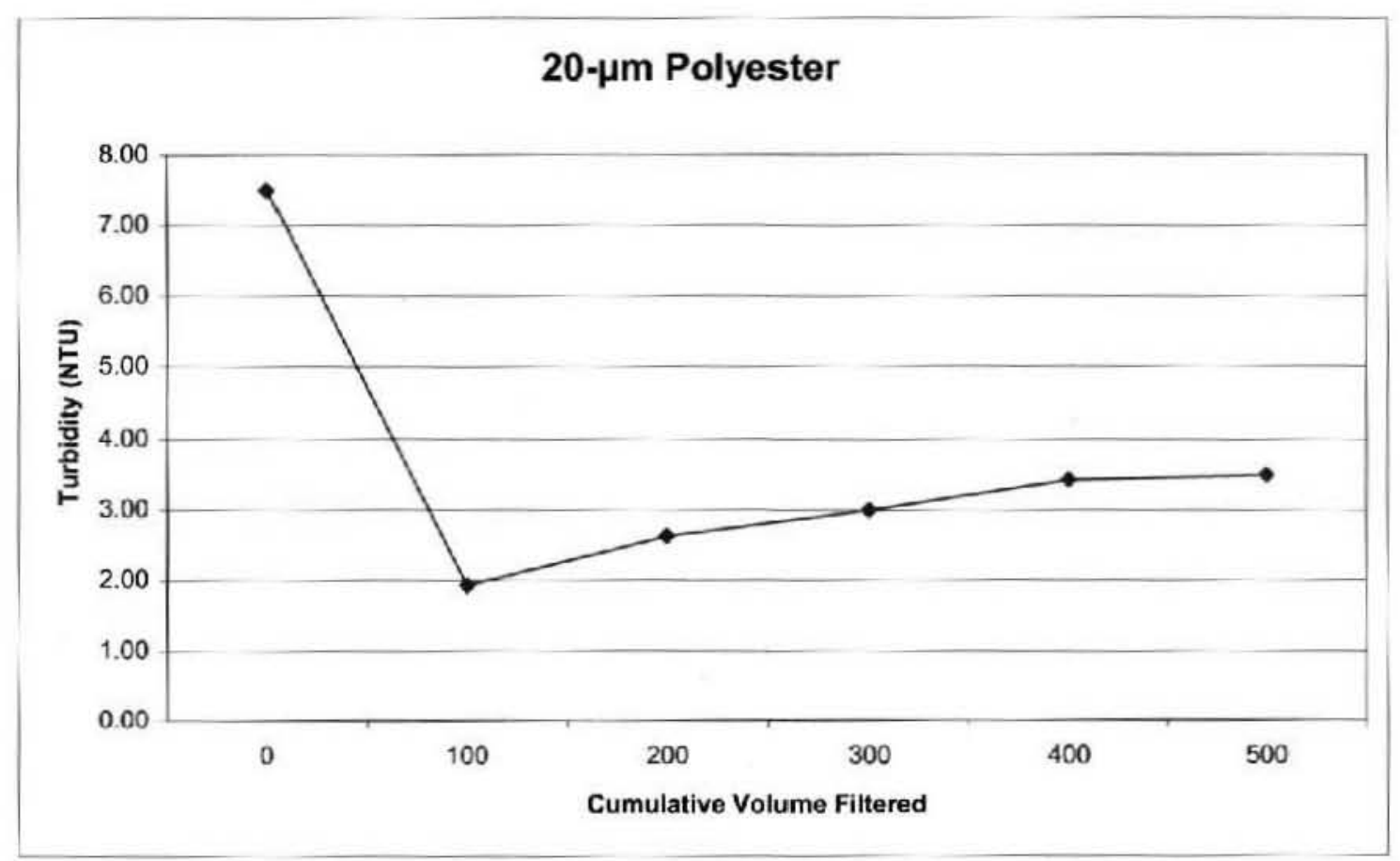

C-2 
RPP-RPT-30093, Rev. 0

Figure C-3. 10- $\mu \mathrm{m}$ Polyester Filter.

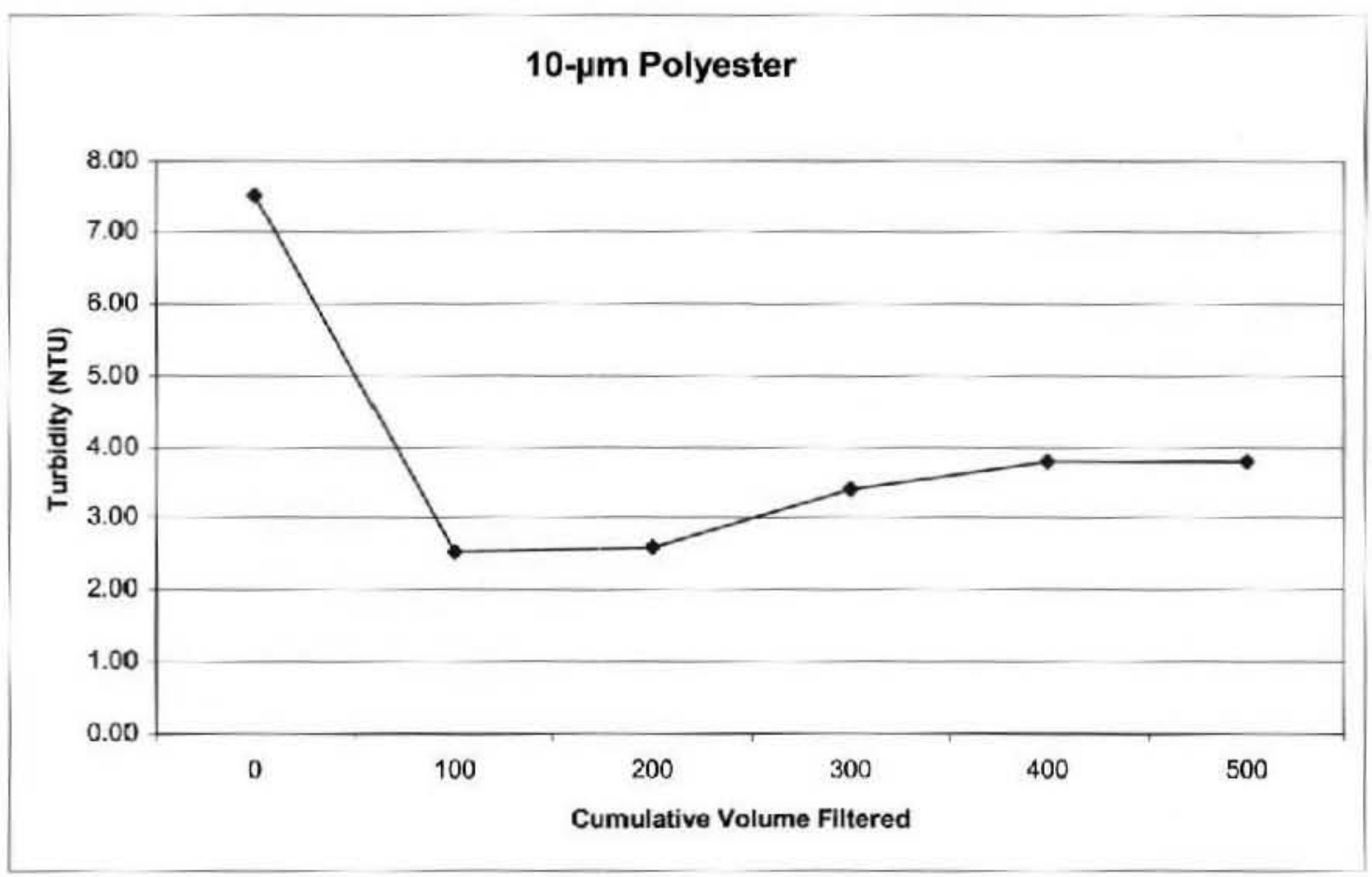

Figure C-4. 5- $\mu \mathrm{m}$ Polyester Filter.

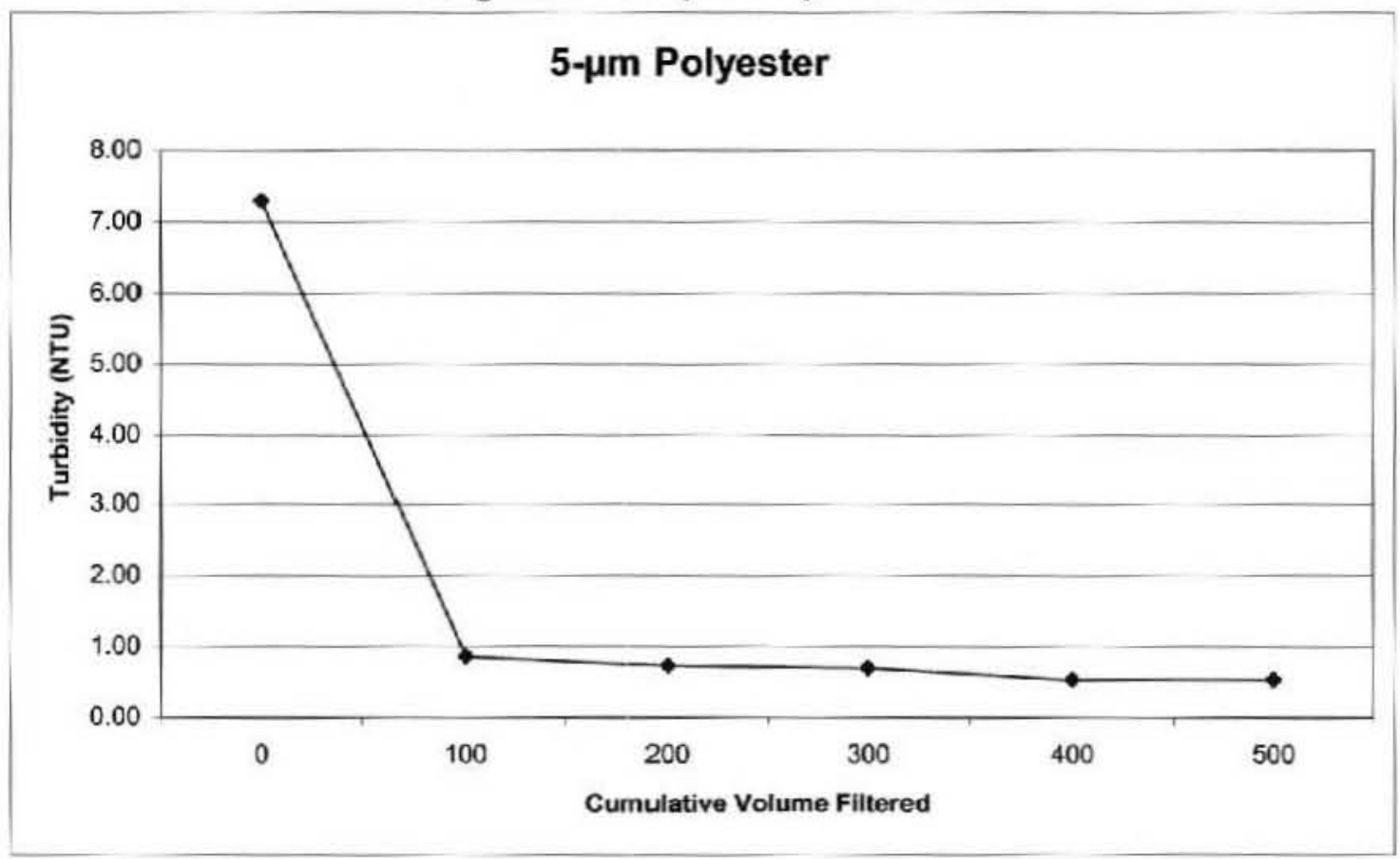


RPP-RPT-30093, Rev. 0

Figure C-5. 5- $\mu \mathrm{m}$ Glass Fiber Filter.

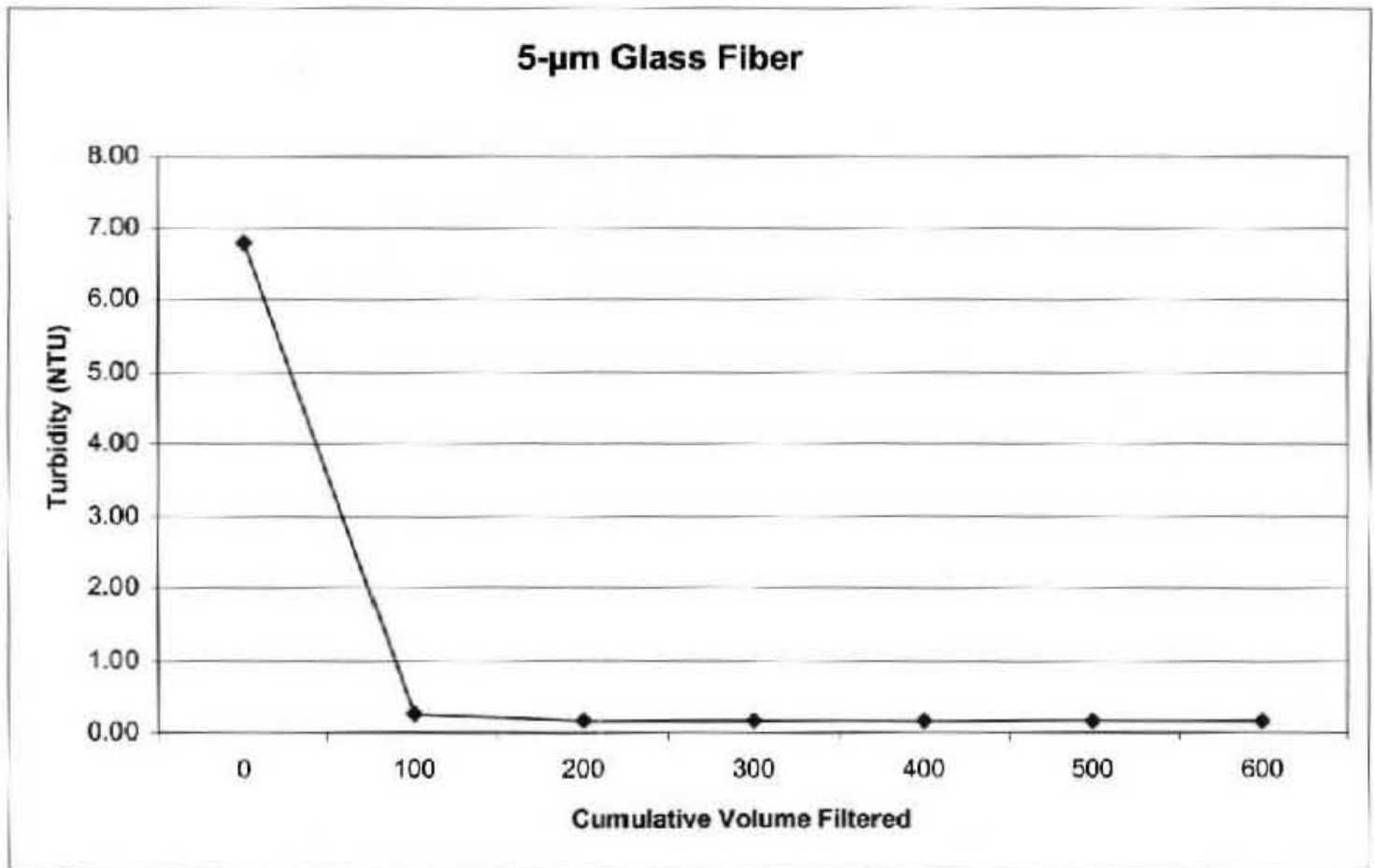

Figure C-6. 1- $\mu \mathrm{m}$ Polyester Filter.

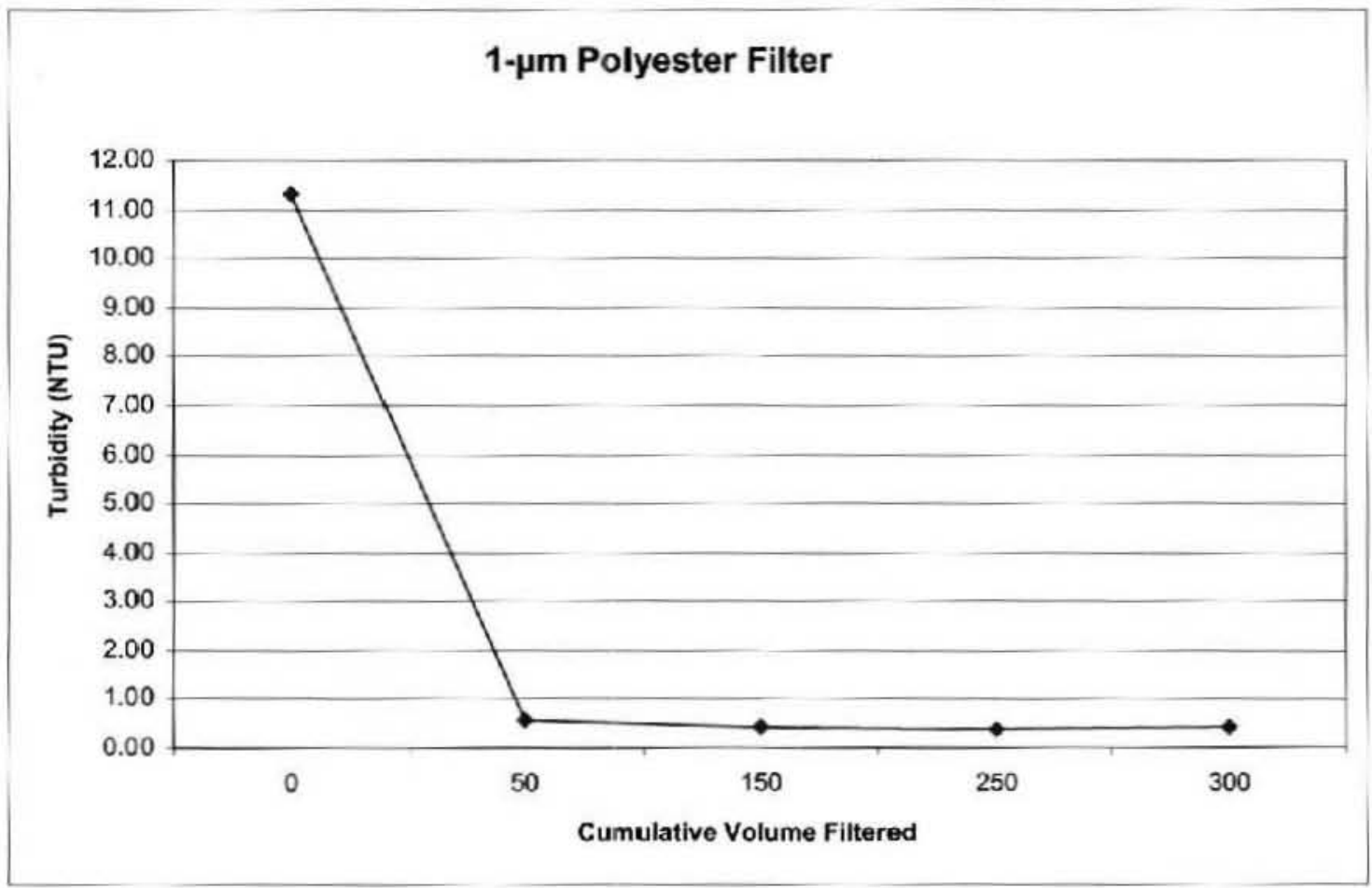

C-4 
RPP-RPT-30093, Rev. 0

Figure C-7. 0.3- $\mu \mathrm{m}$ Glass Fiber Filter.

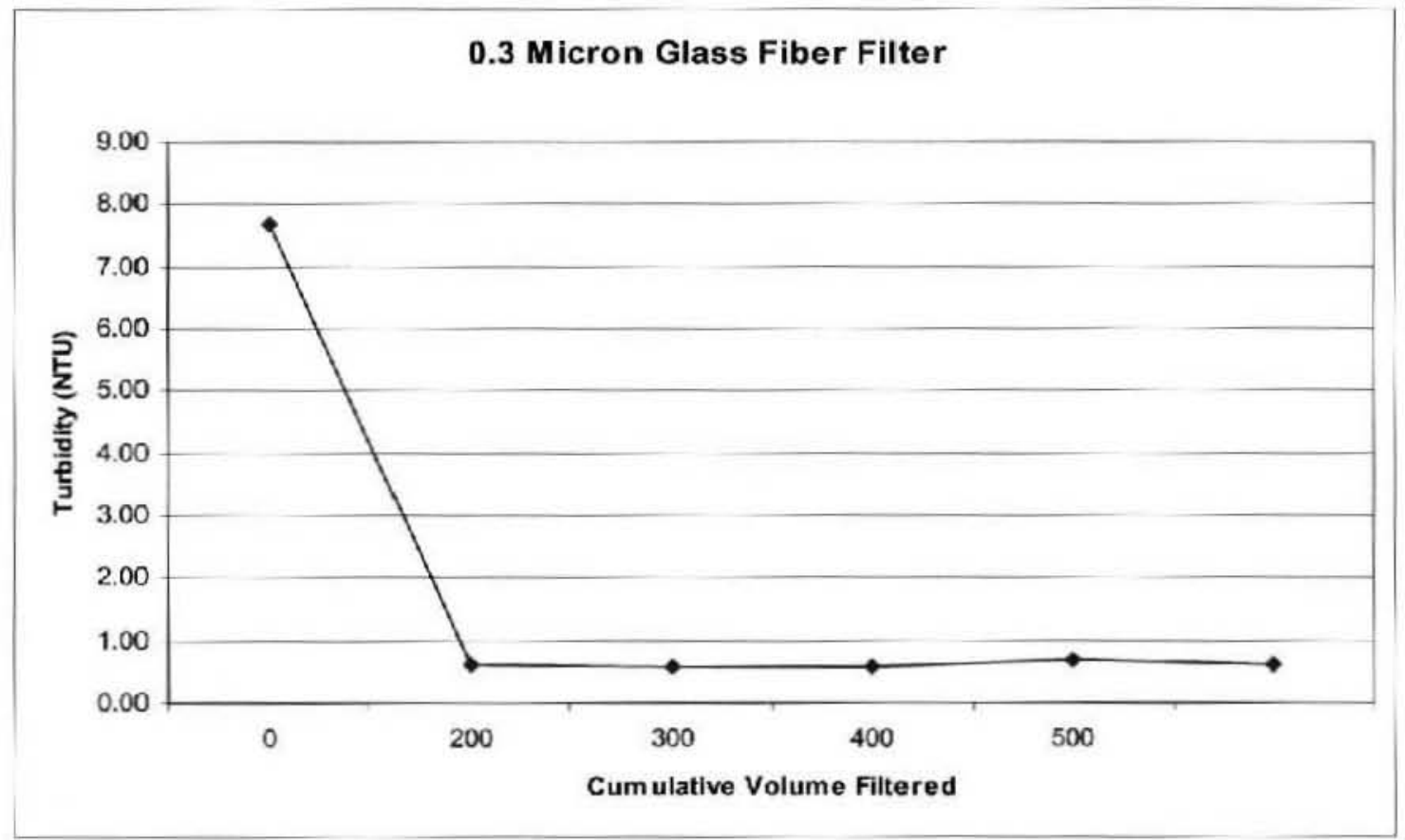


RPP-RPT-30093, Rev. 0

APPENDIX D

LONG RUN TEST: ANALYSES OF 40-MICRON FILTER AND FILTRATE 
Table D-1. Inductively Coupled Plasma Spectroscopy Analyses of 40- $\mu \mathrm{m}$ Filter Filtrate (Labeore SO6K000013).

\begin{tabular}{|c|c|c|c|}
\hline Analyte & $\begin{array}{c}\text { Concentration } \\
(\mathrm{ng} / \mathrm{mL})\end{array}$ & Analyte & $\begin{array}{c}\text { Concentration } \\
(\mu \mathrm{g} / \mathrm{mL})\end{array}$ \\
\hline $\mathrm{Ag}$ (silver) & $\angle 4 \mathrm{E}-03^{3}$ & $\mathrm{P}$ (phosphorous) & $<4.2 \mathrm{E}-02$ \\
\hline Al (aluminum) & $4.15 \mathrm{E}-02$ & $\mathrm{~Pb}$ (lead) & $<3.6 \mathrm{E}-02$ \\
\hline As (arsenic) & $<5.2 \mathrm{E}-02$ & Pd (palladium) & $<3.8 \mathrm{E}-02$ \\
\hline B (boron) & $4.93 \mathrm{E}-02$ & Pr (praseodymium) & $<9 \mathrm{E}-03$ \\
\hline $\mathrm{Ba}$ (barium) & $<7.3 \mathrm{E}-03$ & Rb (nubidium) & $<0.514$ \\
\hline $\mathrm{Be}$ (beryllium) & $<1.2 \mathrm{E}-03$ & Rh (rhodium) & $<2.6 \mathrm{E}-02$ \\
\hline Bi (bismuth) & $<0.102$ & Ru (rutheninm) & $<1.7 \mathrm{E}-02$ \\
\hline $\mathrm{Ca}$ (calcium) & 0.552 & S (sulfur) & 0.444 \\
\hline Cd (cadmium) & $3.46 \mathrm{E}-03$ & Sb (antimony) & $<2.8 \mathrm{E}-02$ \\
\hline $\mathrm{Ce}$ (cerium) & $<1.5 \mathrm{E}-02$ & Se (selenium) & $<6.42 \mathrm{E}-02$ \\
\hline Co (cobalt) & $\angle 8 \mathrm{E}-03$ & Si (silicon) & 0.915 \\
\hline $\mathrm{Cr}$ (chromium) & $<1.4 \mathrm{E}-02$ & Sm (samarium) & $<1.7 \mathrm{E}-02$ \\
\hline Cu (copper) & $<1.4 \mathrm{E}-02$ & Sn (tin) & $<3.4 \mathrm{E}-02$ \\
\hline Eu (europium) & $<1 \mathrm{E}-03$ & Sr (strontium) & $<7 \mathrm{E}-03$ \\
\hline $\mathrm{Fe}$ (imon) & $8.72 \mathrm{E}-02$ & $\mathrm{Ta}$ (tantalum) & $<5.7 \mathrm{E}-02$ \\
\hline $\mathrm{K}$ (potassium) & 0.319 & Te (telluriam) & $<8.4 \mathrm{E}-02$ \\
\hline La (lanthanum) & $<8 \mathrm{E}-03$ & Th (thorium) & $<9 \mathrm{E}-03$ \\
\hline Li (lithium) & $\angle 9 \mathrm{E}-03$ & Ti (titanium) & $7.89 \mathrm{E}-03$ \\
\hline Mg (magnesium) & $3.19 \mathrm{E}-02$ & $\mathrm{Tl}$ (thallium) & $<5.6 \mathrm{E}-02$ \\
\hline Mn (manganese) & $\angle \mathrm{TE}-03$ & $\mathrm{U}$ (uranium) & 0.535 \\
\hline Mo (molybdemum) & $<3 \mathrm{E}-03$ & $\mathrm{~V}$ (vanadium) & $<6 \mathrm{E}-03$ \\
\hline $\mathrm{Na}$ (sodium) & 0.742 & W (tungsten) & $<8.6 \mathrm{E}-02$ \\
\hline Nd (neodymium) & $<8 \mathrm{E}-03$ & $Y$ (ytrium) & $<1.1 \mathrm{E}-02$ \\
\hline $\mathrm{Ni}$ (nickel) & $<2.2 \mathrm{E}-02$ & $\operatorname{Zn}($ zinc) & 7.67E-03 \\
\hline $\mathrm{Nb}$ (niobium) & $<8.4 \mathrm{E}-02$ & $\mathrm{Zr}$ (zirconium) & $<2 \mathrm{E}-02$ \\
\hline
\end{tabular}

"A "<" sign indicated the analyte concentration was below detection limit.

Table D-2. Gamma Energy Analysis 40- $\mu$ m Filter.

\begin{tabular}{|c|c|c|c|c|c|c|}
\hline \multirow{2}{*}{ Sample } & \multirow[b]{2}{*}{ Radionuclide } & \multirow[b]{2}{*}{ HCV/Fliter } & \multirow{2}{*}{$\begin{array}{c}\text { Counting } \\
\text { Error }\end{array}$} & \multicolumn{3}{|c|}{ Total $\mu$ Ci based on Counting Error } \\
\hline & & & & Low & Average & High \\
\hline \multirow{6}{*}{$\begin{array}{l}40-\mu \mathrm{m}, \\
0.078 \mathrm{~g}\end{array}$} & ${ }^{60} \mathrm{Co}$ & $5.64 \mathrm{E}-03$ & 3.93 & $5.41 \mathrm{E}-03$ & $5.64 \mathrm{E}-03$ & $5.86 \mathrm{E}-03$ \\
\hline & ${ }^{137} \mathrm{Cs}$ & 2.133 & 4.23 & 2.04 & 2.133 & 2.22 \\
\hline & ${ }^{152} \mathrm{Eu}$ & $1.73 \mathrm{E}-03$ & 34.42 & $1.13 \mathrm{E}-03$ & $1.73 \mathrm{E}-03$ & $2.32 \mathrm{E}-03$ \\
\hline & ${ }^{136} \mathrm{Eu}$ & $5.69 \mathrm{E}-02$ & 2.2 & $5.56 \mathrm{E}-02$ & $5.69 \mathrm{E}-02$ & $5.81 \mathrm{E}-02$ \\
\hline & ${ }^{155} \mathrm{Eu}$ & $1.37 \mathrm{E}-02$ & 10.82 & $1.22 \mathrm{E}-02$ & $1.37 \mathrm{E}-02$ & $1.52 \mathrm{E}-02$ \\
\hline & ${ }^{311} \mathrm{Am}$ & 0.99 & 5.27 & 0.94 & 0.99 & 1.04 \\
\hline
\end{tabular}

Table D-3. Total Alpha Associated with the 40- $\mu$ Filter.

\begin{tabular}{|c|c|c|c|c|}
\hline Sample & HCl/Filter & Error & HCl/g & $\mathbf{n C l} / \mathbf{g}$ \\
\hline $40 \mu \mathrm{m}$ & 2.11 & 0.624 & 27.05 & 27,050 \\
\hline
\end{tabular}


RPP-RPT-30093, Rev. 0

APPENDIX E

LONG RUN TEST: ANALYSES OF 5-MICRON FILTER AND FILTRATE

E-1 
Table E-1. Induetively Coupled Plasma Spectroscopy Analyses of 5- $\mu \mathrm{m}$ Filter Filtrate (Labcore SO6K000015).

\begin{tabular}{|c|c|c|c|}
\hline Analyte & $\begin{array}{c}\text { Concentration } \\
(\mu \mathrm{g} / \mathrm{mL}) \\
\end{array}$ & Analyte & $\begin{array}{c}\text { Coneentration } \\
(\mu \mathrm{g} / \mathrm{mL})\end{array}$ \\
\hline $\mathrm{Ag}$ (silver) & $\angle A E-03^{\prime \prime}$ & P (phosphorous) & $<4.2 \mathrm{E}-02$ \\
\hline $\mathrm{Al}$ (ahuminum) & $<2.7 \mathrm{E}-02$ & $\mathrm{~Pb}$ (lead) & $<3.6 \mathrm{E}-02$ \\
\hline As (arsenic) & $<5.2 \mathrm{E}-02$ & Pd (palladium) & $<3.8 \mathrm{E}-02$ \\
\hline B (boron) & $5.4 \mathrm{E}-02$ & $\operatorname{Pr}$ (praseodymium) & $<9 \mathrm{E}-03$ \\
\hline $\mathrm{Ba}$ (barium) & $<7.3 \mathrm{E}-03$ & $\mathbf{R b}$ (mubidium) & $<0.514$ \\
\hline Be (beryllium) & $<1.2 \mathrm{E}-03$ & Rh (rhodium) & $<2.6 \mathrm{E}-02$ \\
\hline Bi (bismuth) & $<0.102$ & Ru (nuthenium) & $<1.7 \mathrm{E}-02$ \\
\hline $\mathrm{Ca}$ (calcium) & 0.953 & $S$ (sulfur) & $<5.8 \mathrm{E}-02$ \\
\hline Cd (cadmium) & $\angle \mathrm{E}-03$ & Sb (antimony) & $<2.8 \mathrm{E}-02$ \\
\hline $\mathrm{Ce}$ (cerium) & $<1.5 \mathrm{E}-02$ & Se (selenium) & $<6.42 \mathrm{E}-02$ \\
\hline Co (cobalt) & $<8 \mathrm{E}-03$ & Si (silicon) & 3.14 \\
\hline $\mathrm{Cr}$ (chromium) & $<1.4 \mathrm{E}-02$ & Sm (samarium) & $<1.7 \mathrm{E}-02$ \\
\hline Cu (copper) & $<1.4 \mathrm{E}-02$ & Sn (tin) & $<3,4 \mathrm{E}-02$ \\
\hline Eu (europium) & $<1 \mathrm{E}-03$ & Sr (strontium) & $<7 \mathrm{E}-03$ \\
\hline $\mathrm{Fe}$ (iron) & $<1.3 \mathrm{E}-02$ & Ta (tantalum) & $<5.7 \mathrm{E}-02$ \\
\hline $\mathrm{K}$ (potassium) & $<0.295$ & $\mathrm{Te}$ (tellurium) & $<8.4 \mathrm{E}-02$ \\
\hline La (lanthanum) & $<8 \mathrm{E}-03$ & Th (thorium) & $<9 \mathrm{E}-03$ \\
\hline Li (lithium) & $\angle 9 \mathrm{E}-03$ & Ti (titanium) & $<2 \mathrm{E}-03$ \\
\hline Mg (magnesium) & $8.88 \mathrm{E}-02$ & Tl (thallium) & $<5.6 \mathrm{E}-02$ \\
\hline Mn (manganese) & $<7 \mathrm{E}-03$ & U (uranium) & $<3.1 \mathrm{E}-02$ \\
\hline Mo (molybdenum) & $<3 \mathrm{E}-03$ & $\mathrm{~V}$ (vanadium) & $<6 \mathrm{E}-03$ \\
\hline $\mathrm{Na}$ (sodium) & 1.63 & W (tungsten) & $<8.6 \mathrm{E}-02$ \\
\hline Nd (neodymium) & $<8 \mathrm{E}-03$ & $\mathrm{Y}$ (yttrium) & $<1.1 \mathrm{E}-02$ \\
\hline Ni (nickel) & $<2.2 \mathrm{E}-02$ & $\mathrm{Zn}$ (zinc) & $<4 E-03$ \\
\hline $\mathrm{Nb}$ (niobium) & $<8.4 \mathrm{E}-02$ & $\operatorname{Zr}$ (zirconium) & $<2 \mathrm{E}-02$ \\
\hline
\end{tabular}

- $A$ " $<"$ sign indicated the analyte concentration was below detection limit.

Table E-2. Gamma Energy Analysis of the

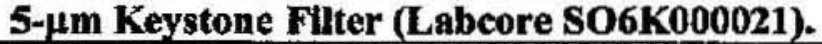

\begin{tabular}{|c|c|c|c|c|c|c|}
\hline \multirow[b]{2}{*}{ Sample } & \multirow{2}{*}{ Radionuclide } & \multirow{2}{*}{ eCuriter } & \multirow{2}{*}{$\begin{array}{c}\text { Counting } \\
\text { Error }\end{array}$} & \multicolumn{3}{|c|}{ Total $\mu C 1$ based on Counting Error } \\
\hline & & & & Low & Average & High \\
\hline \multirow{6}{*}{$\begin{array}{l}5 \mu \mathrm{m}, \\
0.1808 \mathrm{~g}\end{array}$} & ${ }^{60} \mathrm{Co}$ & $2.94 \mathrm{E}-03$ & 5.04 & $2.79 \mathrm{E}-03$ & $2.94 \mathrm{E}-03$ & $1.77 \mathrm{E}-02$ \\
\hline & ${ }^{137} \mathrm{Cs}$ & 1.19 & 4.23 & 1.14 & 1.19 & 1.24 \\
\hline & ${ }^{152} \mathrm{Eu}$ & $9.69 \mathrm{E}-04$ & 44.65 & $5.36 \mathrm{E}-04$ & $9.69 \mathrm{E}-04$ & $1.4 \mathrm{E}-03$ \\
\hline & ${ }^{154} \mathrm{Eu}$ & $2.75 \mathrm{E}-02$ & 2.47 & $2.82 \mathrm{E}-02$ & $2.75 \mathrm{E}-02$ & $2.68 \mathrm{E}-02$ \\
\hline & ${ }^{155} \mathrm{Eu}$ & $6.59 \mathrm{E}-03$ & 13.15 & $7.46 \mathrm{E}-03$ & $6.59 \mathrm{E}-03$ & $5.72 \mathrm{E}-03$ \\
\hline & ${ }^{201} \mathrm{Am}$ & 0.499 & 5.27 & 0.472 & 0.499 & 0.525 \\
\hline
\end{tabular}

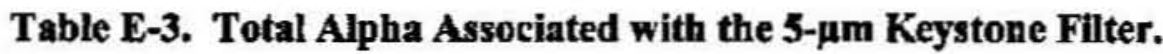

\begin{tabular}{|l|c|c|c|c|}
\hline Sample & $\mu C V$ Cilter & Error & $\mu \mathrm{CV} / \mathrm{g}$ & $\mathrm{nCV} / \mathrm{g}$ \\
\hline $5 \mu \mathrm{m}$ & 1.12 & 0.86 & 6.19 & 6,190 \\
\hline
\end{tabular}


RPP-RPT-30093, Rev. 0

\section{APPENDIX F}

\section{PARTICLE SIZE DISTRIBUTION}




\section{Particle Size Distribution Measurements}

\section{SCOPE}

Particle size distribution (PSD) measurements were requested for three aqueous samples derived from the KE Basin Filtration Efficacy test program:

- KE Basin water composite

- 40- $\mu \mathrm{m}$ filtrate

- 5- $\mu \mathrm{m}$ filtrate

\section{PSD MEASUREMENTS}

\section{Instrumentation}

Measurements of the PSDs of solids suspended in the test samples were performed using the Horiba LA-910 Laser Scattering Particle Size Distribution Analyzer ${ }^{10}$ in hood 2 in room $1 F$ of 222-S. The LA-910 is an ensemble type, light-scattering-based PSD analyzer; it is not a sensingzone or image-analysis type of instrument where measurements or observations of individual particles are made. The composite light-scattering pattern created when a large number of sample particles scatter the light in the focused beam(s) of the analytical probe(s) is measured. Analyzer software, using iterative algorithms based on Mie Scattering Theory, then creates a virtual population of optically isotropic, compositionally homogeneous, spherical particles with a distribution of diameters that would, given the same experimental parameters, generate a similar light-scattering pattern. The reported particle sizes are the diameters of these spherical particles, i.e., equivalent spherical diameters. The frequencies of occurrence of particles of various sizes in the hypothetical populations are weighted according to the volumes of the spherical particles.

The LA-910 analyzer uses dual light sources: a helium-neon laser $(\lambda=632.8 \mathrm{~nm})$ and a $40-\mathrm{W}$, tungsten-halogen, blue-filtered lamp $(\lambda=450 \mathrm{~nm})$. The dual light sources and physical design of the detector array allow measurement of PSDs for samples with particles ranging from $0.02 \mu \mathrm{m}$ to $1020 \mu \mathrm{m}$ in equivalent spherical diameter.

The LA-910 analyzer was operated in flow cell mode for the PSD measurements. In this mode, a dilute suspension of sample solids is continuously circulated through the analyzer measuring loop during PSD measurements. Key components in the loop include the following.

Sample Tank: Sample solids and suspension liquid are introduced into a stainless-steel sample tank (maximum volume $\approx 80 \mathrm{~mL}$ ). Specimen suspensions were limited to $\approx 00 \mathrm{~mL}$ to minimize both contamination within the sample tank compartment and the volume of analytical waste generated. Suspensions enter the measurement loop from the bottom of the tank.

\footnotetext{
${ }^{10}$ Horiba is a registered trademark of Horiba, Ltd. Corporation Japan, Kyoto, Japan.
} 
Stirrer: A three-bladed mechanical stirrer in the sample tank assists in suspending the sample solids in the suspension liquid and is critical in introducing a uniform sample suspension into the flow loop. The stirrer speed is adjustable in seven step settings, ' 1 ' through ' 7 '. In distilled water, a stirrer setting of ' 6 ' represents a stirring speed of $\approx 000$ revolutions/minute.

A stirrer speed setting of '2' was used for these measurements. Tests have shown that this stirrer speed is the minimum required to effectively sample spherical particles with density $\approx 2.5 \mathrm{~g} / \mathrm{cm}^{3}$ and with diameters up to $350 \mu \mathrm{m}$ in aqueous suspensions.

Ultrasonic Generator: The sample tank is also the chamber of a low-power $(40 \mathrm{~W}, 39 \mathrm{kHz})$ ultrasonic bath. This ultrasonic bath is provided to facilitate dispersion of sample particulates in the suspension liquid. The power of the bath is fixed. The operator may select whether or not to activate the ultrasonic generator. If activated, the operator may adjust the time the bath operates before the light-scattering measurement begins and the length of any delay period between termination of the ultrasonic treatment and initiation of the PSD measurement. The operator may also elect to continue ultrasonic treatment during the light-scattering measurement. For brevity, ultrasonic treatment of samples hereafter is referred to as "sonication."

Circulation Pump: Located immediately downstream from the sample tank, a variable-occlusion peristaltic pump circulates the sample slurry through the analyzer measurement loop. The pump speed is adjustable in seven step settings, ' 1 ' through ' 7 '. A pump speed setting of ' 4 ' was used for these measurements. The discharge volume at this pump speed setting is $\Rightarrow \mathrm{mL} / \mathrm{s}$ using Tygon $^{11}$ tubing with an internal diameter of $4.8 \mathrm{~mm}$.

The occlusion of the Masterflex ${ }^{12}$ peristaltic pump head is adjusted so that the pump tubing is not totally compressed (occluded) at any point of the rotor rotation. Performance tests using this occlusion setting and various pump and stirrer speed combinations have shown that a stirrer speed of ' 2 ' combined with a pump speed of ' 4 ' is the minimum combination required to satisfactorily measure the PSD of a certified standard containing soda-lime glass microspheres $\left(\rho=2.4-2.5 \mathrm{~g} / \mathrm{cm}^{3}\right)$ with diameters ranging from $50 \mu \mathrm{m}-350 \mu \mathrm{m}--$ Whitehouse Scientific ${ }^{13}$ standard PS223.

Measurement Cell: The flow cell is located immediately downstream from the circulation pump. The two optical windows of the cell are Tempax ${ }^{14}$ glass (with a nonreflective coating on the exterior surfaces) and define an interior specimen cavity with dimensions of $70 \mathrm{~mm} \times 45 \mathrm{~mm} \times 3.5 \mathrm{~mm}(\mathrm{H} \times \mathrm{W} \times \mathrm{D})$. The analytical light probes traverse paths through the depth of the cell perpendicular to the cell windows. The sample suspension enters at the bottom of the measurement cell, exits at the top of the cell, and returns to the sample tank.

\footnotetext{
"Tygon is a registered tradernark of Norton Company, Worcester, Massachusetts.

${ }^{12}$ Masterflex is a registered trademark of the Cole-Parmer Instrument Company, Vernon Hills, Illinois.

${ }^{13}$ Whitehouse Scientific, Waverton, Chester, England.

14 Tempax is a registered trademark of Schott Glaswerkes, Mainz, Germany.
} 


\section{Specimens}

The specimens analyzed were $200-\mathrm{nL}$ portions of the test water samples. The supplied test samples were first thoroughly mixed by inversion and rotation of the original bottles for a minimum of 1 minute. Then, as quickly as possible, a $50-\mathrm{mL}$ portion was withdrawn from the bottom third of the sample using a large bore pipette and transferred to a beaker. This process was repeated three additional times. The $200-\mathrm{mL}$ specimen was then poured into the analyzer sample tank. The transfer beaker was then rinsed twice with small volumes of reagent water that were added to the test specimen.

Ten drops of an aqueous solution of sodium hexametaphosphate $\left[\left(\mathrm{NaPO}_{3}\right)_{6}\right]$ were added to the test specimens, as a chemical dispersant, prior to PSD measurements. The final concentration of $\left(\mathrm{NaPO}_{3}\right)_{6}$ was $<0.05 \mathrm{wt} \%$.

\section{Measurements}

Particle size distribution measurements were made on three specimens (A, B, and C) withdrawn from each test sample. The PSD measurement on each specimen was a set of two sequential PSD runs.

The procedure for completing a set of PSD runs on a single specimen was as follows:

1. A large volume of laboratory reagent water was filtered through a $0.2-\mu \mathrm{m}$ membrane filter immediately prior to the PSD measurements.

2. Approximately $175 \mathrm{~mL}$ of filtered water and 10 drops of $\left(\mathrm{NaPO}_{3}\right)_{6}$ solution were added to the analyzer sample tank.

3. The pump speed was set to ' 5 ' and the stirrer speed to ' 2 ' and the blank charge was sonicated for 2 minutes. [This treatment ensures the measurement loop is free from particles and bubbles.]

4. The pump speed was set to '4' and the stirrer speed to ' 2 ' and a blank measurement was completed.

5. The blank water charge was then drained from the analyzer.

6. $200 \mathrm{~mL}$ of test specimen and 10 drops of $\left(\mathrm{NaPO}_{3}\right)_{6}$ solution were added to the analyzer sample tank.

7. Run 1 analyzer settings (Table 1) were established and the specimen charge was allowed to stir and circulate for 30 seconds.

8. The Run 1 measurement sequence was started.

9. When Run 1 was complete, the presence of a saved data file was verified, Run 2 analyzer settings were established, and the Run 2 measurement sequence was started.

10. When Run 2 was complete, the presence of a saved data file was verified.

11. The specimen suspension was drained from the analyzer. The analyzer was then flushed with reagent water until the light-scattering pattern returned to a particulate-free profile. 
The analyzer settings and sequence times that were used in each PSD run are presented in Table 1.

Table 1. Particle Size Distribution Analyzer Measurement Run Settings.

\begin{tabular}{|c|c|c|c|c|c|c|}
\hline \multirow{2}{*}{ 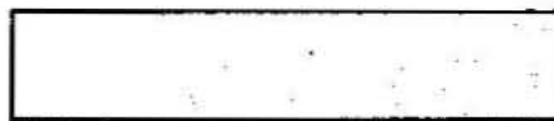 } & \multirow{2}{*}{$\begin{array}{c}\text { Sample } \\
\text { Load-In }\end{array}$} & \multicolumn{5}{|c|}{ PSD Measurement Run } \\
\hline & & 1 & 2 & & & \\
\hline \multicolumn{7}{|l|}{ Analyzer settings } \\
\hline Pump (circulation) speed setting & 4 & 4 & 4 & - & - & - \\
\hline Stirrer (agitation) speed setting & 2 & 2 & 2 & - & - & - \\
\hline Premeasurement working & . & $\cdots$ & & & & \\
\hline Work time (seconds) & 30 & 10 & 120 & - & - & - \\
\hline Ultrasonics ON & No & No & YES & 一 & - & - \\
\hline Premeasurement wait (seconds) & $\mathrm{n} / \mathbf{a}$ & 0 & 10 & - & $\cdots$ & - \\
\hline Measurement & $\therefore:$ & $\ldots$ & & 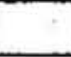 & & - \\
\hline Measure cycles (laser/lamp) & $\mathrm{n} / \mathrm{a}$ & $60 / 12$ & $60 / 12$ & - & 一 & - \\
\hline Snnication during measure & $\mathrm{n} / \mathrm{a}$ & No & No & - & 二 & 一 \\
\hline Total sonication time (minutes) & 0 & 0 & 2 & - & - & 一 \\
\hline Total time (minutes:seconds) ${ }^{\mathrm{b}}$ & $0: 30$ & $1: 40$ & 5:05 & - & - & - \\
\hline
\end{tabular}

A composite measurement combining 60 readouts of detectors while illuminating sample with the $\mathrm{He}$-Ne laser and 12 readouts while illuminating the sample with the blue-filtered lamp. Total measurement time $=60$ sec.

${ }^{b}$ Cumulative measurement time. Setting up and initiating each PSD run takes $\$ 15 \mathrm{sec}$ based on previous measurement experience.

\section{Optical Model}

Conversion of the light-scattering patterns measured by the analyzer to PSDs requires input of a relative refractive index-

$$
\text { RRI = Refractive index (particles) / Refractive index (liquid medium). }
$$

The accuracy of this input becomes increasingly important as the diameters of the particles become smaller than $\approx 5 \mu \mathrm{m}$ (ISO 13320-1).

The complex refractive index $(\mathrm{N})$ of a substance is defined as

$$
\mathrm{N}=\boldsymbol{n}-\boldsymbol{k i},
$$

where the real index, $n$, represents the degree of refraction of light in the material. The complex (or imaginary) part of the index, $k \mathrm{i}$, is directly proportional to the degree of attenuation (primarily by absorption) of the probe light beam(s) by a material. Transparent materials have small extinction coefficients $(k)$; opaque and/or highly colored materials have larger coefficients. 
In practice, it is assumed that a suspension liquid that strongly absorbs at the wavelength(s) of the analytical probes will not be used and that minor absorption by the liquid will be accounted for by blank measurements. The RRI value actually input is

$$
\mathrm{RRI}=\left(n_{\mathrm{p}} / n_{\mathrm{m}}\right)-k_{\mathrm{p}} \mathrm{i}
$$

The suspension liquid was assumed to be pure water with a real refractive index, $n_{\mathrm{m}}=1.333$ (at $\lambda=589.3 \mathrm{~nm}$ ).

The sample solids were assigned an index of refraction of $\mathrm{N}_{\mathrm{p}}=1.60-0.10 \mathrm{i}$.

The RRI value input in the PSD calculations was

$$
R R I=\left(n_{p} / n_{m}\right)-k_{p} \mathrm{i}=(1.60 / 1.333)-0.1 \mathrm{i}=1.20-0.10 \mathrm{i}
$$

[If the client has input suggesting that an alternate RRI value would be more appropriate or desirable, PSDs can be recalculated using revised value(s) without reanalysis of physical specimens.]

\section{DEVIATIONS}

Ideally, particle concentration in sample suspensions should be above a minimum level required to produce an acceptable signal-to-noise ratio. In the LA-910 analyzer this concentration corresponds to a reduction in \%-transmission to about $95 \%$ (reduction in transmission of the probe light beam through the suspension by $5 \%$ relative to the particle-free suspension liquid). To avoid multiple scattering, the solids concentration should be below a level that corresponds to about $65 \%$-transmission for particles larger than $20 \mu \mathrm{m}$ and about $85 \%$-transmission for smaller particles (ISO 13320-1).

The three test samples all had very small concentrations of solids. Values of light transmission (\%-T) observed were

\begin{tabular}{|l|c|c|c|c|}
\hline \multirow{2}{*}{} & \multicolumn{2}{|c|}{ Laser \%-T } & \multicolumn{2}{c|}{ Lamp \%-T } \\
\cline { 2 - 5 } & Run 1 & Sonicated & Run 1 & Sonicated \\
\hline Reagent water & 100 & 100 & 100 & 100 \\
\hline KE water cormposite & 98.5 & 98.8 & 98.3 & 98.0 \\
\hline $40-\mu$ m filtrate & 99.3 & 99.6 & 99.4 & 99.4 \\
\hline 5 - $\mu$ m filtrate & \multicolumn{2}{|c|}{ Not Measured } & \multicolumn{2}{c|}{ Not Measured } \\
\hline
\end{tabular}

The solids concentration in the $5-\mu \mathrm{m}$ filtrate sample was so low that the analyzer was not able to distinguish the specimen from the reagent water blank and PSD measurements were not possible.

\section{PSD MEASUREMENT RESULTS}

The results of the light-scattering-based PSD measurements are presented in this section. As previously noted, measurements on the composite and $40-\mu \mathrm{m}$ filtrate were made in triplicate. For each sample, the data files for corresponding PSD Runs from the triplicate specimens were 
combined into 'average' data files. The PSD histograms, \%-undersize curves, and numerical data derived from these average data files are presented here. [Complete transcripts of all PSD data can be provided on request.]

The scattered-light parterns measured by the LA-910 analyzer are directly related to the volumes of small particles and the cross-sectional area of larger particles. The primary analyzer outputs are PSDs with frequencies of occurrence weighted according to the volumes of the scattering particles. The analyzer software allows these primary distributions to be recalculated as area-, length-, or number-based distributions. These converted distributions are obtained by re-weighting the original, partially processed, volume-based data using the appropriate power of the particle diameters (d) and then renormalizing the resulting distributions. For example, number-based PSDs are obtained by applying weighting factors proportional to $1 / \mathrm{d}^{3}$ to the original volume-based PSD data. Particle size data derived from both the volume-based and the recalculated number-based PSDs are included.

Particle size distribution data for the test samples is based on standard-form distributions (as opposed to the "sharp-form" alternative in the analyzer algorithms). These distributions are generally characterized by broad, poorly resolved features but are appropriate for the calculation of PSDs of samples with unknown composition and morphology and/or a wide range of particle diameters.

All the PSD data presented are calculated using an RRI value of $1.20-0.10 \mathrm{i}$.

\section{Histograms and \%-Undersize Carves}

The volume-based histograms and \%-undersize curves depicting the averaged results of the triplicate PSD measurements on the composite and $40-\mu \mathrm{m}$ filtrate samples are presented in Figures 1 and 2, respectively.

The volume-based histograms and cumulative curves of Figures 1 and 2 are plotted using a common particle diameter ( $x$-axis) scale, $0.1 \mu \mathrm{m}-500 \mu \mathrm{m}$. No particulates with diameters $<0.1 \mu \mathrm{m}$ or $>500 \mu \mathrm{m}$ were observed in any calculated PSD for the test samples. To further facilitate comparison of the graphic data, all the volume-based, PSD histogram data are also plotted against a common frequency-\% (y-axis).

In Figure 3, the volume-based, $\%$-undersize curves for the composite and 40 - $\mu \mathrm{m}$ filtrate samples are plotted on common axes to illustrate the overall differences in the PSDs for the two measured test samples.

The number-based PSD histograms and \%-undersize curves for the averaged run data are presented in Figures 4 and 5. As in Figures 1 and 2, the averaged number-based PSDs are displayed against common diameter and frequency- $\%$ axis. 


$$
\text { RPP-RPT-30093, Rev. } 0
$$

Figure 1. Volume-based Particle Size Distributions of KE-Basin Water Composite. (Average of triplicate measurements.)

(a) Run 1-Ultrasonic Time: 0.00 minutes

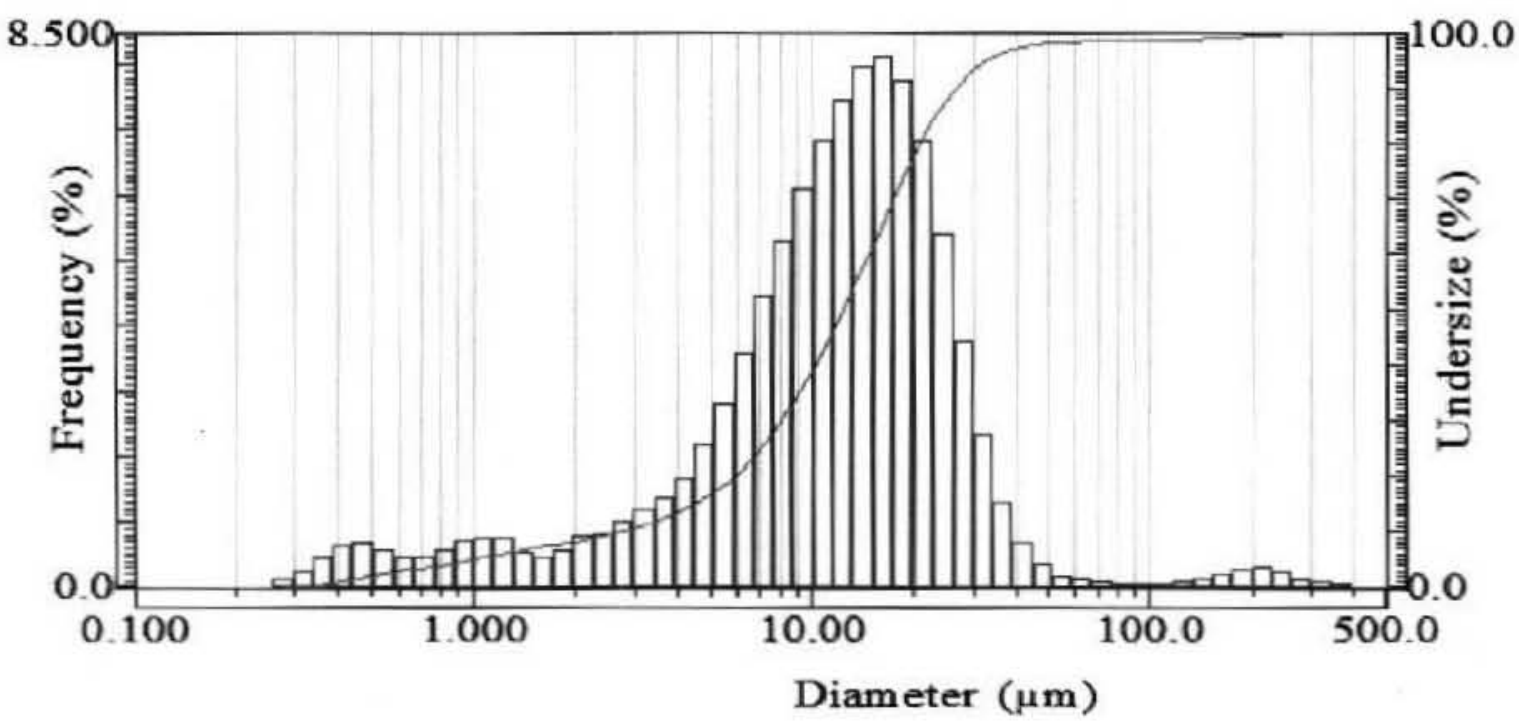

(b) Run 2-Ultrasonic Time: 2.00 minutes

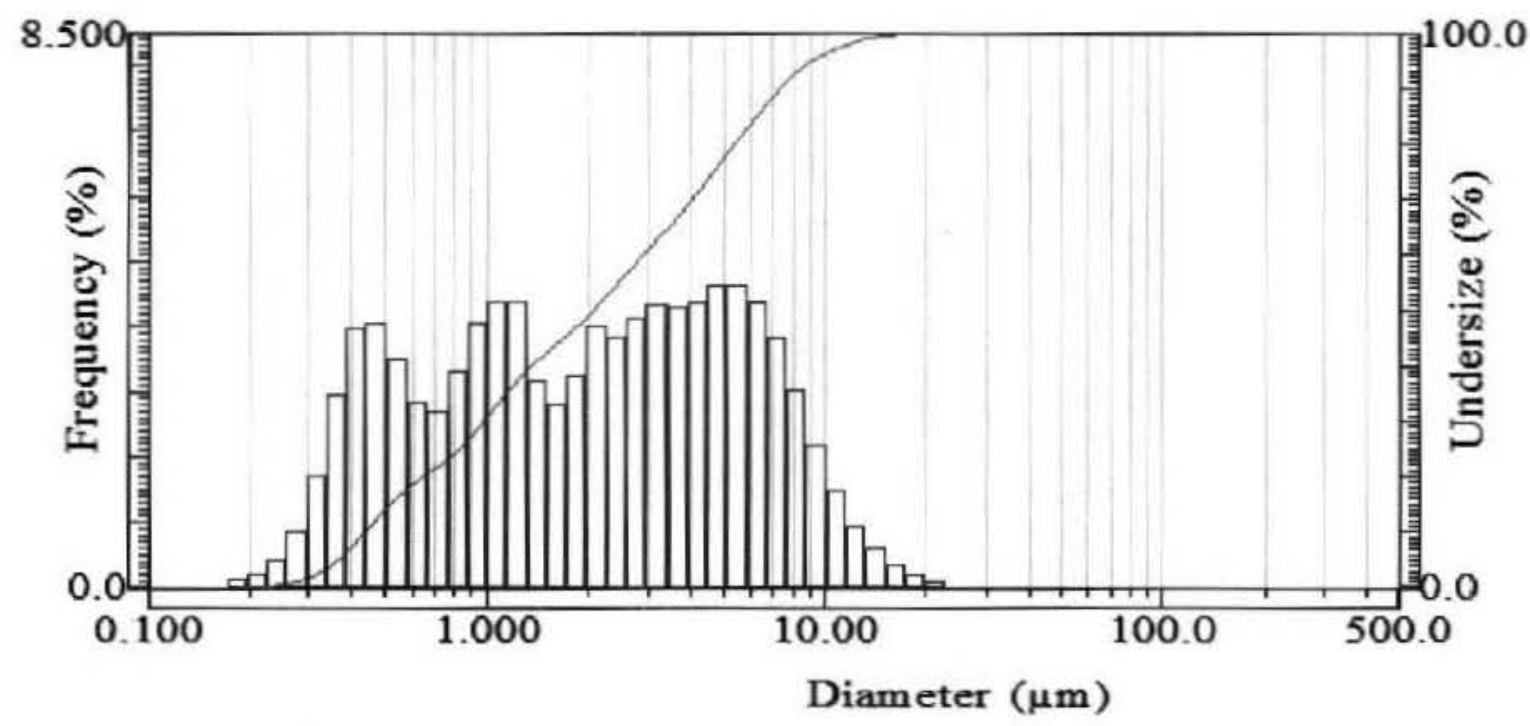


Figure 2. Volume-based Particle Size Distributions of $40-\mu \mathrm{m}$ Filtrate. (Average of triplicate measurements.)

(a) Run 1-Ultrasonic Time: 0.00 minutes

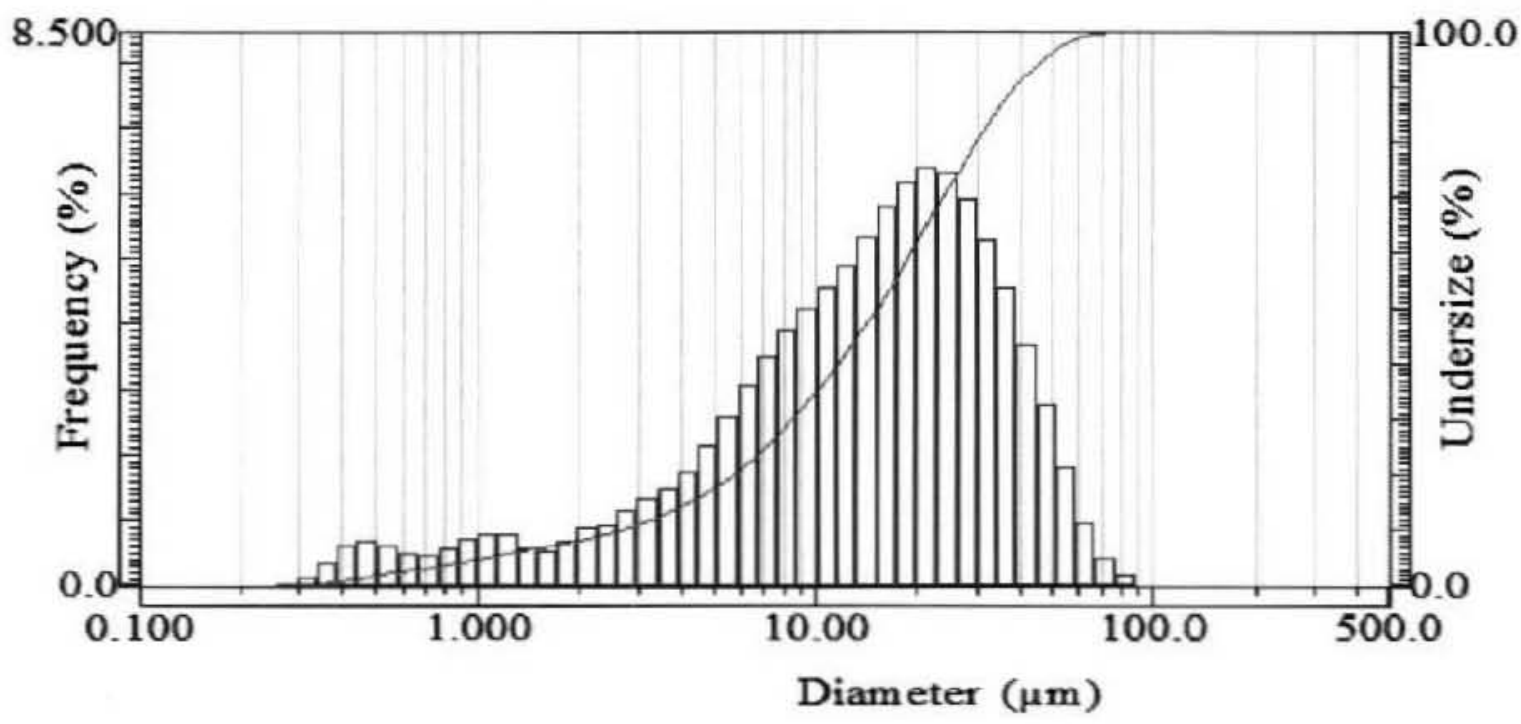

(b) Run 2-Ultrasonic Time: 2.00 minutes

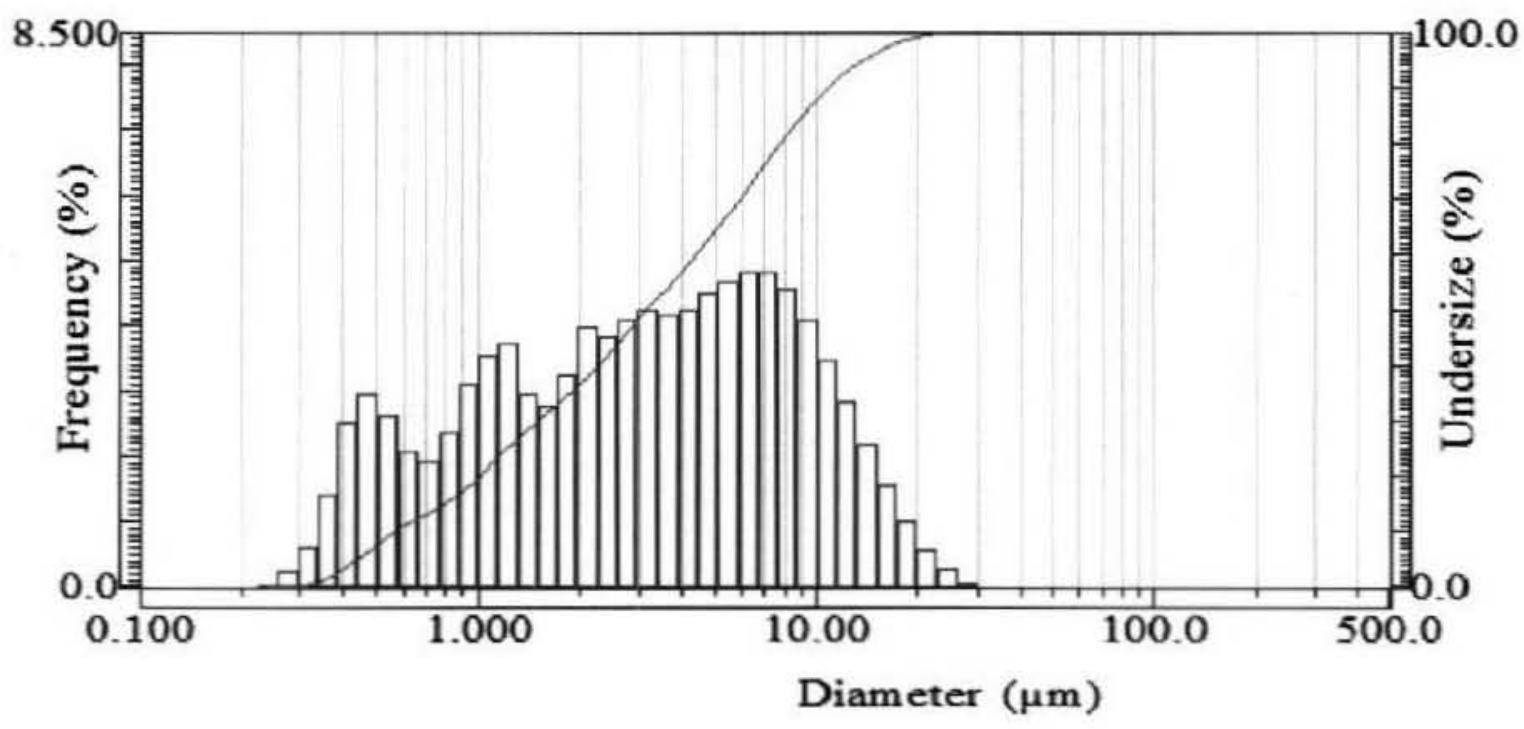


Figure 3. Comparison of Volume-based Cumulative \%-Undersize Curves.

(Solid Blue Lines: KE composite. Dashed Red Lines: $40-\mu \mathrm{m}$ filtrate)

(a) Run 1-Ultrasonic Time: 0.00 minutes

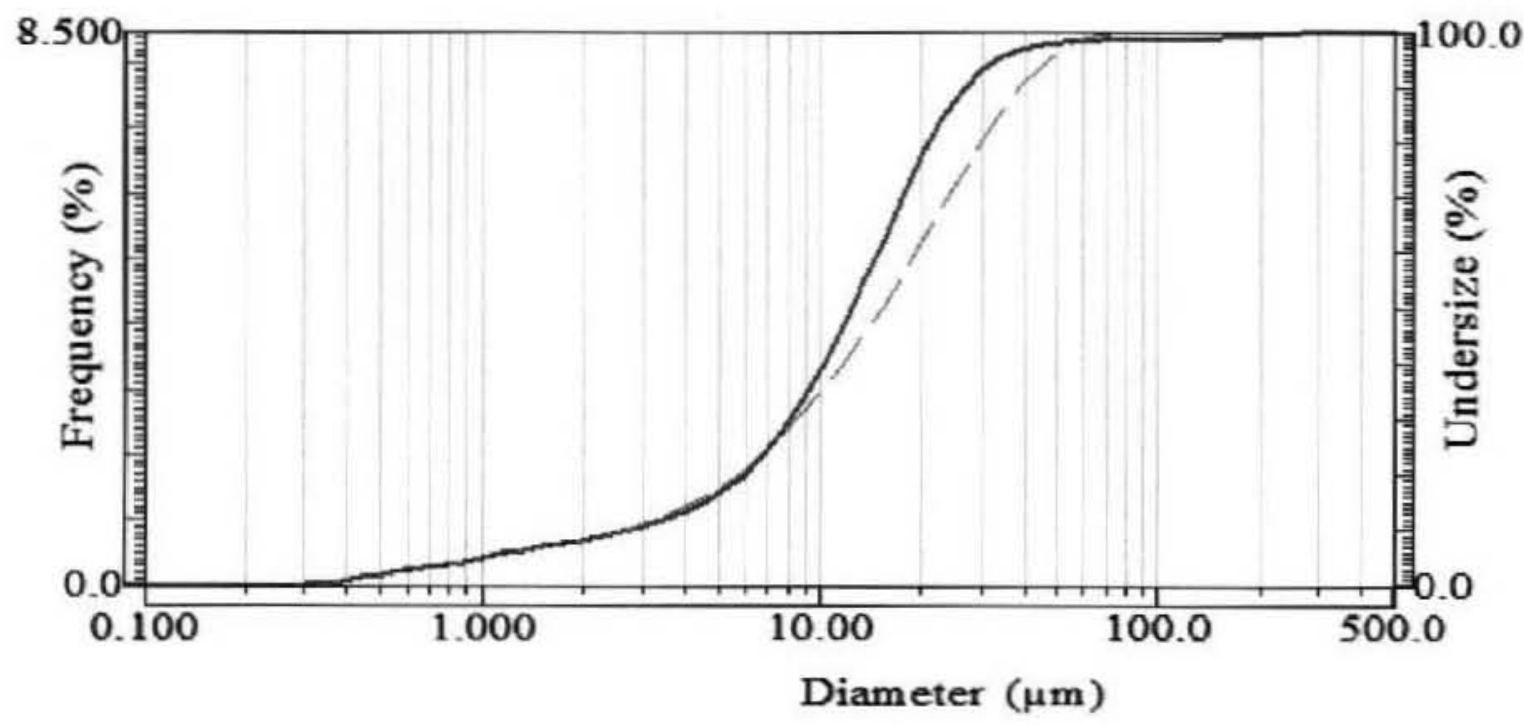

(b) Run 2 Ultrasonic Time: 2.00 minutes

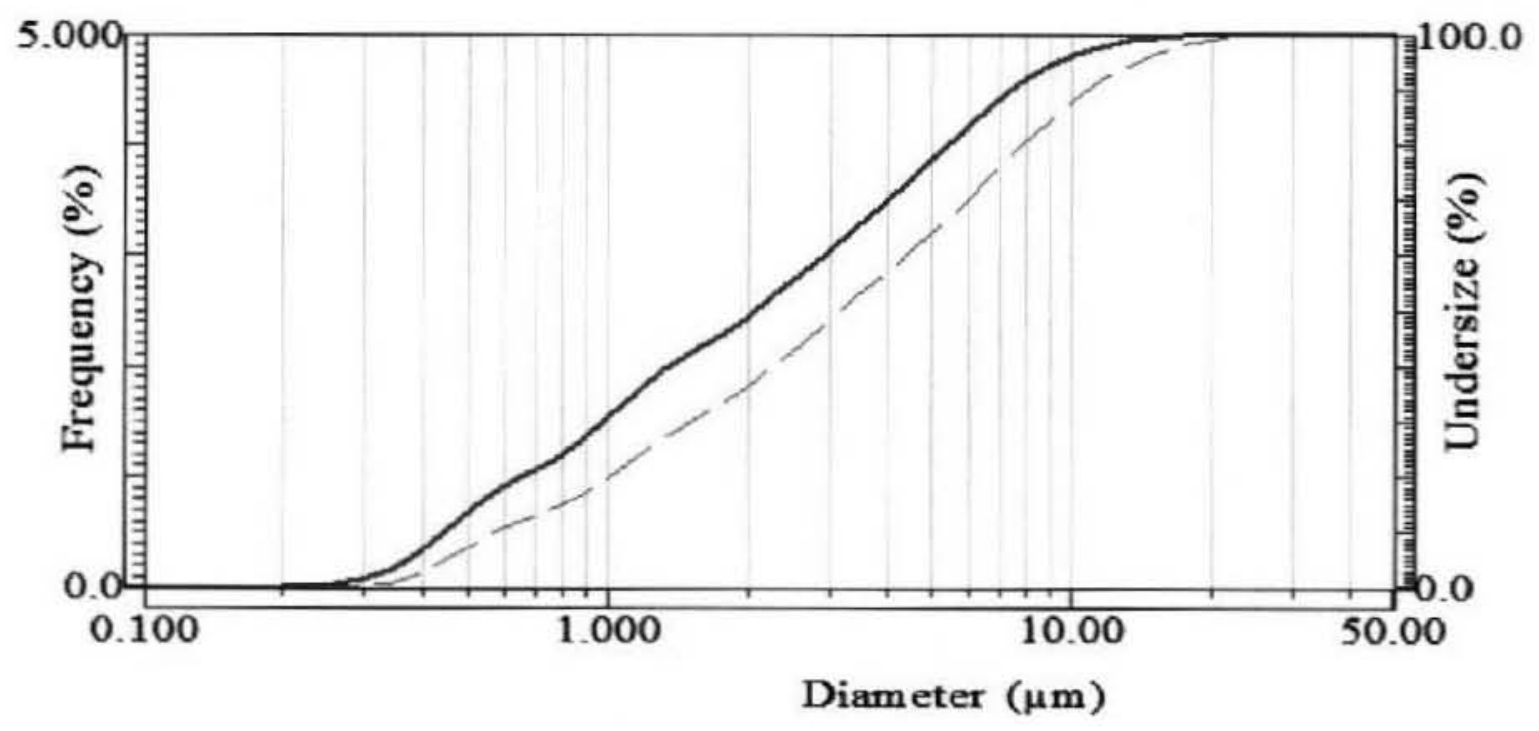


RPP-RPT-30093, Rev. 0
Figure 4. Number-based Particle Size Distributions of KE-Basin Water Composite.
(Average of triplicate measurements.)

RPP-RPT-30093, Rev. 0
Figure 4. Number-based Particle Size Distributions of KE-Basin Water Composite.
(Average of triplicate measurements.)

RPP-RPT-30093, Rev. 0
Figure 4. Number-based Particle Size Distributions of KE-Basin Water Composite.
(Average of triplicate measurements.)

(a) Run 1-Ultrasonic Time: 0.00 minutes

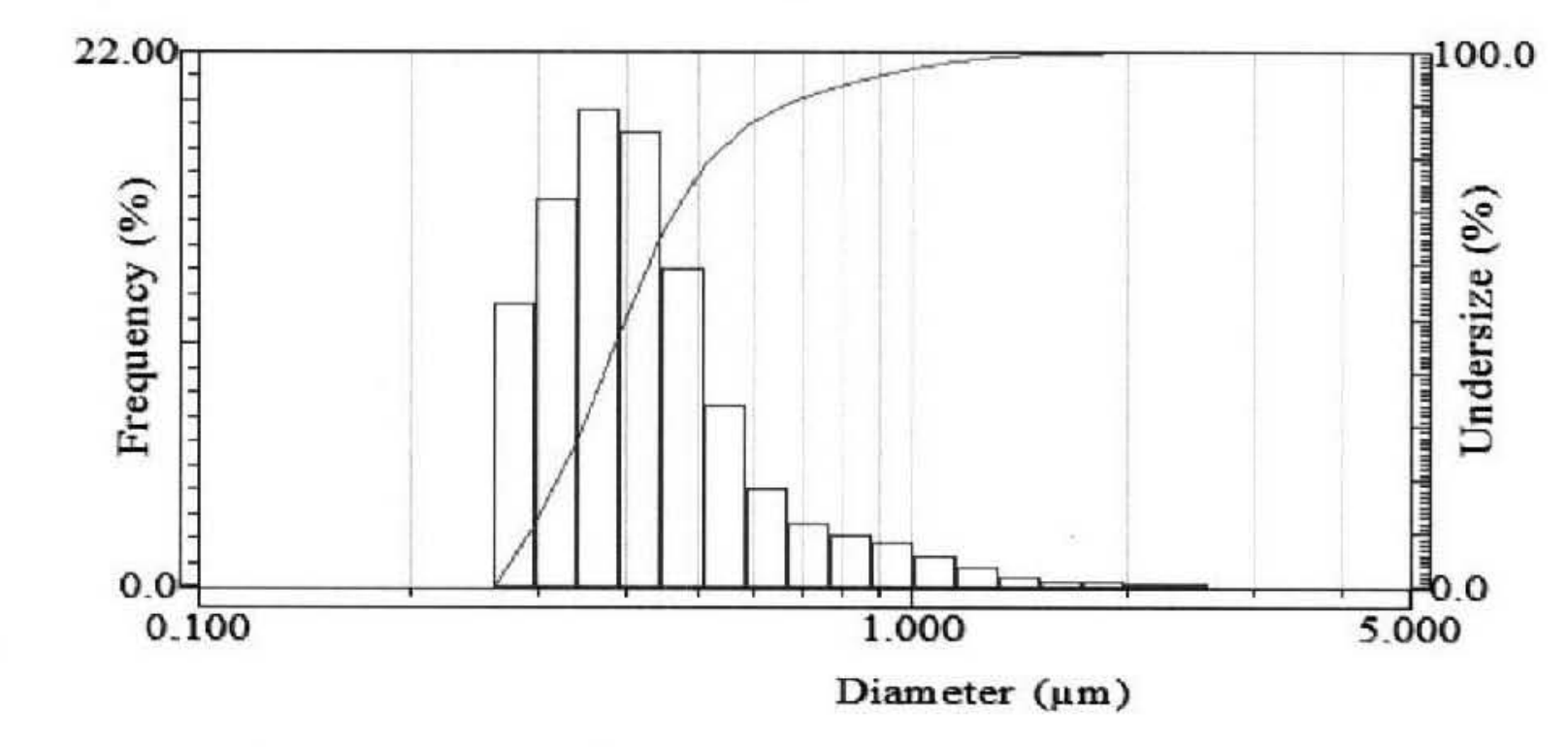

(b) Run 2-Ultrasonic Time: 2.00 minutes

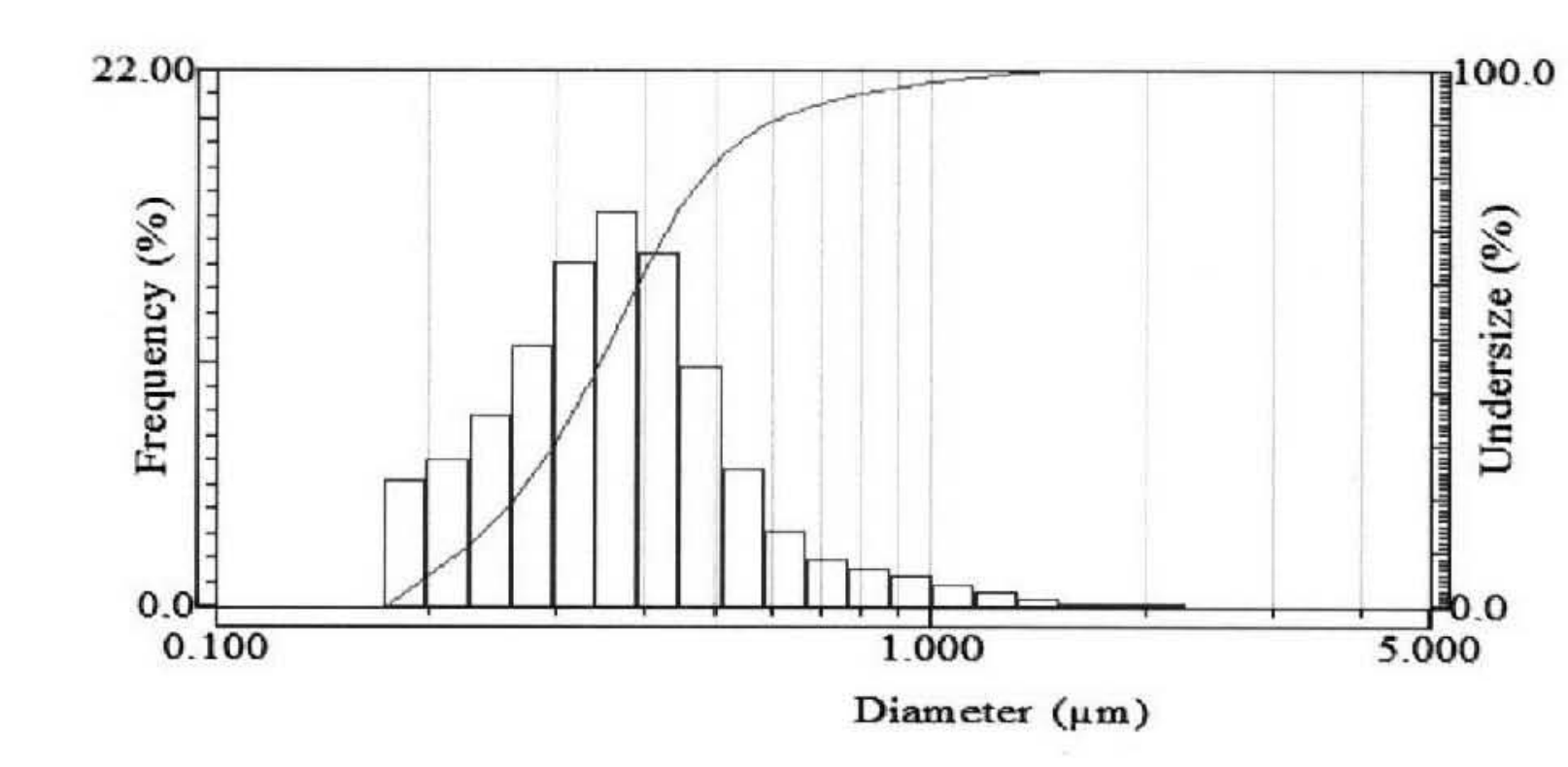


Figure 5. Number-based Particle Size Distributions of $40-\mu \mathrm{m}$ Filtrate.

(Average of triplicate measurements.)

(a) Run 1-Ultrasonic Time: 0.00 minutes

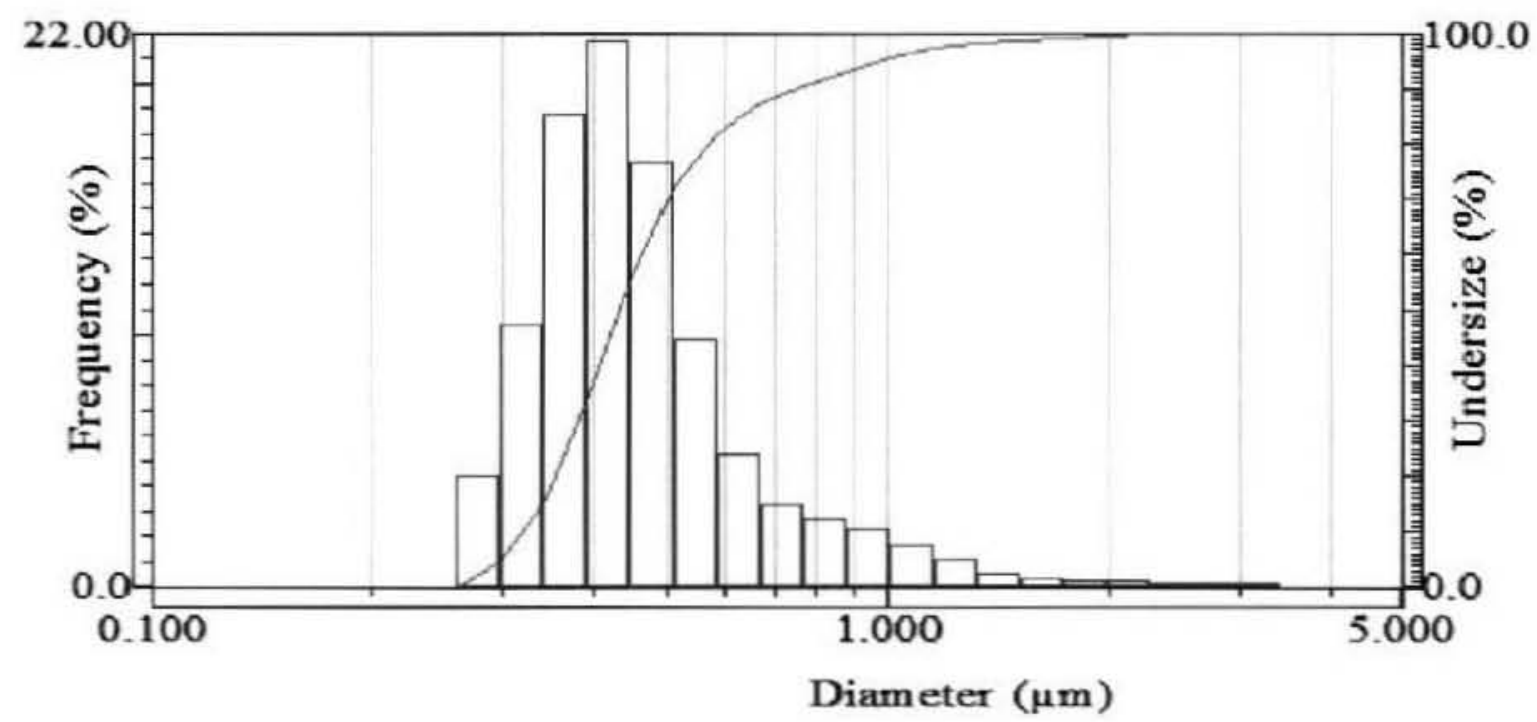

(b) Run 2 Ultrasonic Time: 2.00 minutes

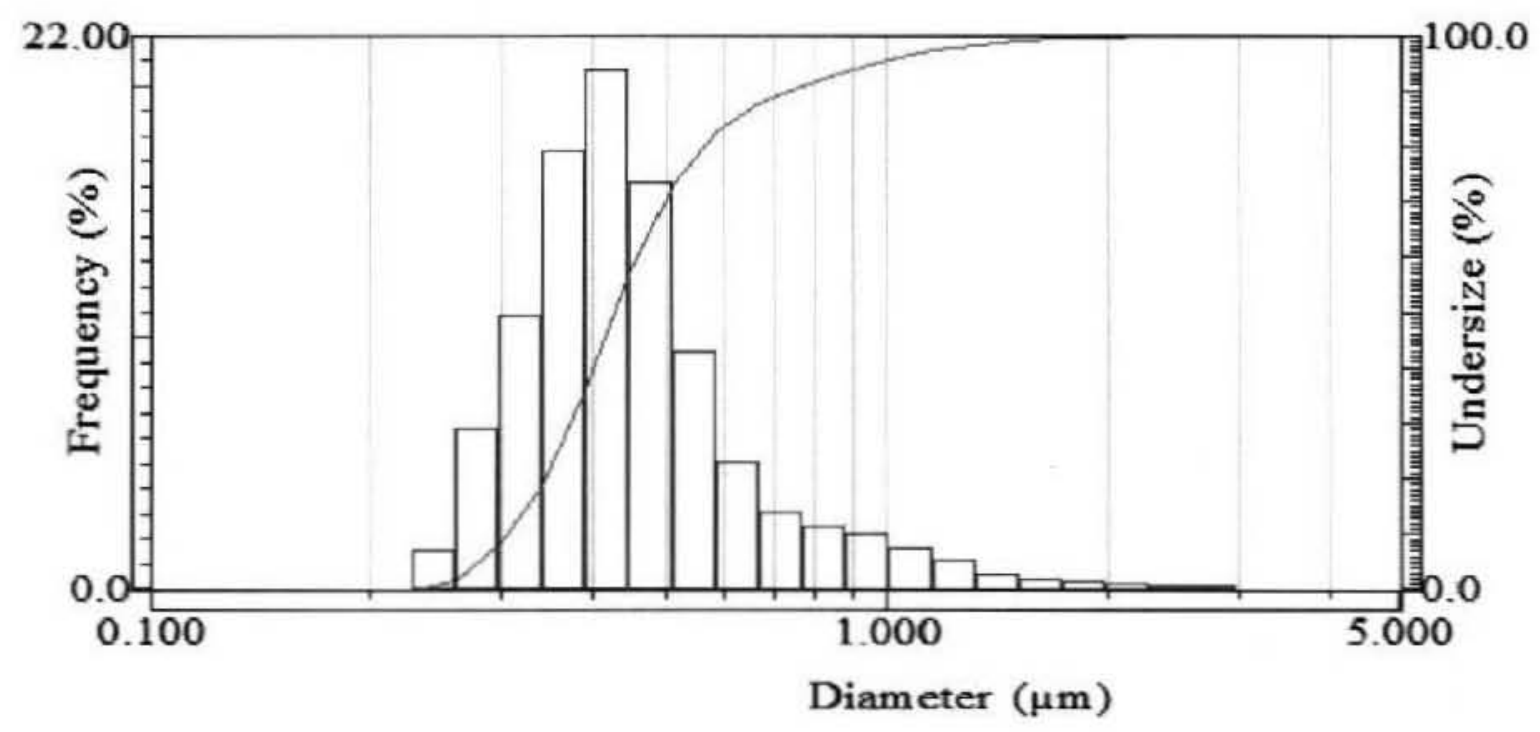




\section{Cumulative \%-Undersize Data}

The particle diameters associated with five pre-selected points on the cumulative \%-undersize curves describing the volume-based PSDs for the composite and $40-\mu \mathrm{m}$ filtrate samples are presented in Table 2. The default data sets generated by the LA-910 analyzer consist of 80 logarithmically-spaced particle-diameter bins that are populated with occurrence frequency data. A software option allows this process to be reversed: "Diameter-on-\%" occurrence frequency values are pre-selected and then associated with particle diameters extracted from the calculated PSDs. The particle diameters associated with 10-, 25-, 50-, 75-, and $90 \%$-undersize selections are presented in the table. The $50 \%$-undersize values are, by definition, the median particle diameters of the PSDs.

The number-based, \%-undersize data extracted from the averaged PSD measurements is presented in Table 3.

Table 2. Volume-based, Cumulative \%-Undersize Data.

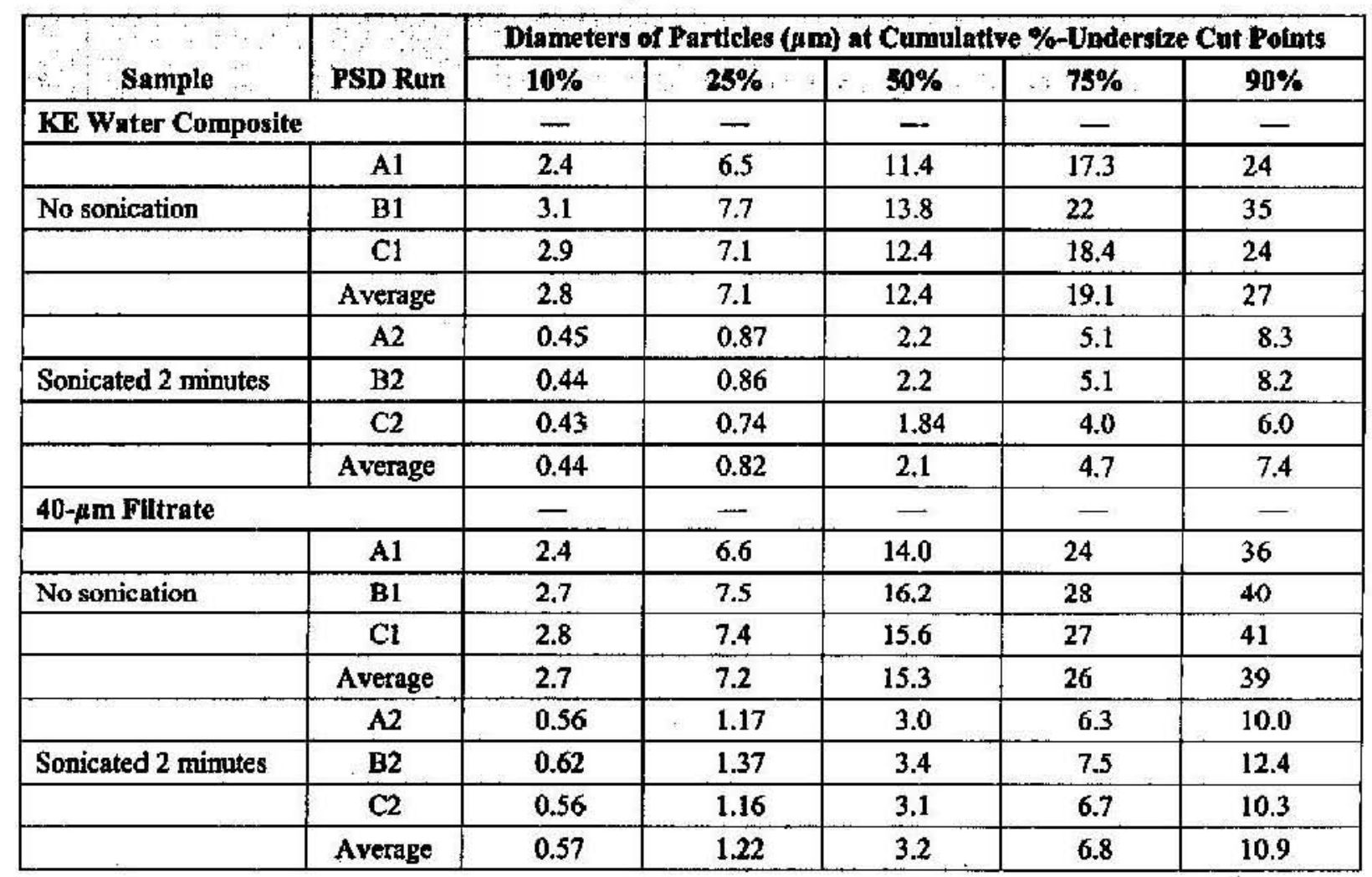


Table 3. Number-based Cumulative \%-Undersize Data.

\begin{tabular}{|c|c|c|c|c|c|c|}
\hline \multirow{2}{*}{ Sample } & \multirow[b]{2}{*}{ PSD Run } & \multicolumn{5}{|c|}{ Dlameters of Particles $(\mu \mathrm{m})$ at Cumulative \%-Undersize Cut Points } \\
\hline & & $10 \%$ & $25 \%$ & $50 \%$ & $75 \%$ & $90 \%$ \\
\hline \multicolumn{7}{|l|}{ KE Water Composite } \\
\hline No sonication & Average & 0.29 & 0.33 & 0.40 & 0.49 & 0.66 \\
\hline Sonicated 2 minutes & Average & 0.22 & 0.28 & 0.36 & 0.45 & 0.59 \\
\hline \multicolumn{7}{|l|}{ 40-um Filtrate } \\
\hline No sonication & Average & 0.32 & 0.37 & 0.43 & 0.53 & 0.75 \\
\hline Sonicated 2 minutes & A verage & 0.30 & 0.36 & 0.43 & 0.53 & 0.75 \\
\hline
\end{tabular}

\section{PSD CAVEATS}

Light-scattering-based PSD measurements are based on several assumptions:

a. All sample particles are spherical.

b. All particles with diameters less than $\approx 25 \mu \mathrm{m}$ are compositionally and/or optically identical.

c. The optical properties of both the particles and the suspending medium are well known when samples contain particles with diameters less than $\approx 25 \mu \mathrm{m}$.

d. There is no interaction between light scattered from different particles (i.e., no multiple scattering phenomena).

Deviations from these assumptions will introduce some degree of error in the PSD measurements due to the inability of the deconvolution and inversion algorithms to account for the deviations.

It should also be reemphasized that the Horiba LA-910 is an ensemble type, light-scatteringbased PSD analyzer, not a sensing-zone or image-analysis type of instrument. Direct observation and/or measurement of individual particles are not made. The calculated PSDs are based, in part, on assumptions regarding the shapes and statistical properties of distributions that may not apply to the samples being measured.

\section{Measurement Range}

The results reported for the PSD analyses only apply to particles with diameters within the $0.02 \mu \mathrm{m}-1020 \mu \mathrm{m}$ measuring range of the analyzer. The calculated PSDs are normalized so that the sum of the occurrence frequencies of particles within this range is always $100 \%$. This should not be taken to represent that particles with diameters $<0.02 \mu \mathrm{m}$ or $>1020 \mu \mathrm{m}$ were determined, by measurement, to be absent from the samples.

Visual observation during mixing and transfer of PSD specimens to the analyzer did not suggest that any discrete particles or strongly bound aggregates with dimensions approaching or exceeding $1020 \mu \mathrm{m}$ were present in any of the samples. The presence of particles with diameters $<0.02 \mu \mathrm{m}$ cannot be ruled out. 


\title{
Nonspherical Particles
}

\begin{abstract}
All light-scattering-based PSD data are presented in terms of an equivalent spherical diameterthe diameter of a spherical particle having the same light-scattering function as that assigned to the sample particle. By design, a nonlaminar, quasi-turbulent flow regime is maintained in the LA-910 flow cell. Under ideal conditions, the equivalent spherical diameter reported for any nonspherical particle would be derived from a combination of all cross-sectional diameters that a rapidly and randomly rotating particle could present to the probe light beams. The degree to which measurements on any significantly nonspherical component of a real, nonuniform sample actually achieves this ideal cannot be determined without undertaking an extensive study including both light-scattering-based and direct measurements of particle dimensions. This type of developmental program was not performed as part of these measurements.
\end{abstract}

It is unknown whether the test samples contain significant amounts of nonspherical particles. The degree to which PSD measurements on these solids have yielded a meaningful, averaged spherical diameter is similarly unknown.

\section{Dispersion of Sample Particles}

Laser diffraction instruments cannot distinguish between scattering by single particles and scattering by clusters of primary particles forming an agglomerate or aggregate. Usually the measured particle size for agglomerates is related to the cluster size, but sometimes the size of the primary particles is reflected in the PSD as well (ISO 13320-1). Furthermore, no technique not based on direct observation of sample solids can distinguish between agglomerates that may exist in a sample in its native state and agglomerates that may form as a result of the measurement process (e.g., by introduction of the sample solids into a different liquid medium with different electrostatic properties). As a result, ensuring a good degree of dispersion prior to sample analysis is generally considered to be an important step to ensure reliable and reproducible size analysis (NIST 960-1, NIST Recommended Practice Guide: Particle Size Characterization).

In the current PSD measurements, Run 1 on each specimen was made under conditions where dispersion of sample solids was purposefully minimized. The uniform shift to smaller particle diameters observed in Runs 2 suggests that at least a portion of the initial solids were either loosely bound aggregates or fragile primary particles. The degree to which the particulates described by the Run 2 PSDs represent primary particles in the water samples is not known.

\section{Refractive Indexes}

In numerous cases, the results of a particle size analysis are only as good as the optical model chosen to interpret and convert the measured pattem of scattered light into a PSD (NIST 960-1). In particular, input of accurate refractive indexes of the sample solids and suspension liquid to the algorithms can be of critical importance.

When particle diameters are much larger than the wavelength of the light probe(s), scattering is effectively described as Fraunhofer diffraction and is independent of the optical properties of the 
sample material. To describe the scattering of light by smaller particles (down to diameters somewhat smaller than the light wavelength), use of Mie Scattering Theory is required. Application of Mie Theory requires that the complex refractive indexes of both the (assumed optically isotropic and spherical) particulate phase $\left(\mathrm{N}_{\mathrm{p}}\right)$ and the suspension liquid $\left(\mathrm{N}_{\mathrm{m}}\right)$ be known. This requirement is of increasing importance as the (a) particle diameters approach or become smaller than the wavelength(s) of the light scattered, (b) particles become increasingly transparent to the light probe(s), (c) particulates significantly absorb at the wavelength(s) of the light probe(s), and/or (d) refractive indexes of the liquid and solid phases approach one another.

The minimum particle size at which the Fraunhofer approximation holds varies depending on the actual solid-liquid system being measured. As a general rule (ISO 13320-1), the accuracy of the optical model data is not a significant concern for particles with diameters $>50 \mu \mathrm{m}$ and has only minor impact for particles with diameters as small as $18 \mu \mathrm{m}$ to $25 \mu \mathrm{m}$ for the $450-\mathrm{nm}$ and $632-\mathrm{nm}$ light sources employed in the LA-910 analyzer. The input of accurate optical data is of increasing importance as the diameters of sample particles become smaller than $25 \mu \mathrm{m}$ and is critical when particles diameters are less than $1 \mu \mathrm{m}-2 \mu \mathrm{m}$.

The solids in the KE Basin water samples were arbitrarily assigned a refractive index of $\mathrm{N}_{\mathrm{p}}=1.60-0.10 \mathrm{i}$. There is no experimental or theoretical basis that supports this value.

A small change in the assigned RRI may cause a significant change in calculated PSDs. Also, the effect of the RRI on PSDs calculated for samples containing particles of diverse composition and morphology is, generally, quite complicated. Unfortunately, it is sometimes somewhat difficult, even for a single well-defined phase, to obtain an accurate value for the real index of refraction $\left(n_{\mathrm{p}}\right)$. Moreover, it is often very difficult to obtain an accurate value for the imaginary component $\left(k_{\mathrm{p}} \mathrm{i}\right)$ of the refractive index: absorption is often strongly dependent on wavelength, and the extinction coefficient can also be affected by surface structure of the particles (e.g., surface roughness) and intraparticle density heterogeneity. Indeed, it is common practice to determine appropriate values for the imaginary part (and often the real part also) of the refractive index using trial-and-error procedures of size determination using a microscopy-based technique, a light-scattering-based instrument, and samples of the solids to be measured.

\section{Specimen Size}

As was previously noted, none of the three KE Basin water samples had a sufficient level of solids loading to allow PSD measurements to be completed within the desired 85- to $95 \%$-transmission range. Indeed, the 5- $\mu \mathrm{m}$ filtrate sample could not be distinguished from the reagent water blank and PSD measurements could not be completed. The PSD results for the composite and 40- $\mu \mathrm{m}$ filtrate samples may be somewhat quantitatively compromised.

Also, volume-based PSD measurements can be very sensitive to the presence of small numbers of large-diameter particles that can nevertheless represent a very large fraction of the sample particulate volume. For example, a single particle $50 \mu \mathrm{m}$ in diameter in a population of $1 \times 10^{6}$ particles, the balance of which are all $0.5 \mu \mathrm{m}$ in diameter, would have a number-based occurrence frequency of $0.0001 \%$. However, in a volume-based distribution the single $50-\mu \mathrm{m}$ particle would represent $50 \%$ of the particulate volume. Clearly, in samples containing a broad 
range of particle sizes, obtaining an analytical specimen in which the relative proportions of large and small particles are accurately represented is of importance.

Sampling statistics indicate that a specimen that will accurately and reproducibly represent the proportion of the larger particles in such a sample must be of a minimum weight or volume [Particle Size Measurement: Volume ] - Powder Sampling and Particle Size Measurement (Allen 1997)]. It is almost certain, at least for the Run 1 PSD measurements, that none of the specimens for the composite or $40-\mu \mathrm{m}$ filtrate samples contained these amounts of solids.

\section{QUALITY CONTROL}

\section{Replicate Measurements}

As previously noted, PSD measurements were performed on triplicate portions (specimens) withdrawn from each test sample. [Complete results for each of the PSD measurements are available on request.] The agreement of the triplicate Rum 1 and Run 2 measurements for each sample was generally quite good, particularly for the Run 2 PSDs. The level of agreement is demonstrated by the numerical data presented in Table 2 .

\section{Standard Measurements}

Measurements of the PSDs of certified particle size standards were performed before sample measurements began and after they were completed. Measurements were completed on three, certified particle size standards: two samples of monodisperse, polystyrene microspheres, and one sample of monodisperse, soda-lime glass spheres. Standard measurement results are summarized in Table 4.

Table 4. Results of Measurements of Certified Standards.

\begin{tabular}{|l|l|c|c|}
\hline \multicolumn{1}{|c|}{ Identincation } & \multicolumn{1}{c|}{ Type } & \multicolumn{1}{c|}{ Certiffed } & Measured \\
\hline $\begin{array}{l}\text { Duke Scientific } \\
\text { 4016A-Lot 27406 }\end{array}$ & Polystyrene microspheres & $1.587 \pm 0.025 \mu \mathrm{m}$ & $1.727 \pm 0.132 \mu \mathrm{m}$ \\
\hline $\begin{array}{l}\text { Duke Scientific } \\
\text { 3150A-Lot 27050 }\end{array}$ & Polystyrene nanospheres & $152 \pm 5 \mathrm{~nm}$ & $152 \pm 10 \mathrm{~nm}$ \\
\hline $\begin{array}{l}\text { Whitehouse Scientific } \\
\text { MS0091-Lot } 0038\end{array}$ & Soda-lime glass spheres & $91.2 \pm 0.9 \mu \mathrm{m}$ & $95.1 \pm 5.0 \mu \mathrm{m}$ \\
\hline
\end{tabular}

All measured mean particle diameters for the standards were within $\pm 10 \%$ of the certified mean values. 
RPP-RPT-30093, Rev. 0

\section{REFERENCES}

Allen, T., 1997, Particle Size Measurement: Volume 1-Powder Sampling and Particle Size Measurement, Fifth Edition, Powder Technology Series, Chapman and Hall, New York, New York.

ISO-13320-1, 1999, Particle Size Analysis - Laser Diffraction Methods - Part 1: General Principles, First Edition, International Organization for Standardization, Geneva, Switzerland.

NIST Special Publication 960-1, 2001, NIST Recommended Practice Guide: Particle Size Characterization, National Institute of Standards and Technology, U.S. Department of Commerce, Gaithersburg, Maryland. 
RPP-RPT-30093, Rev. 0

\section{APPENDIX G}

PARTICLE SIZE DISTRIBUTION FOR KEYSTONE AND PALL 10-MICRON GLASS FIBER FLTERS 
RPP-RPT-30093, Rev. 0

\section{KE-BASIN FILTRATION EFFICACY TESTS August 2006}

\section{Particle Size Distribution Measurements}

\section{SCOPE}

Particle size distribution (PSD) measurements were requested for four aqueous samples derived from the second phase of the KE Basin Filtration Efficacy test program:

\begin{tabular}{ll}
\multicolumn{1}{c}{ Labcore No. } & \multicolumn{1}{c}{ Description } \\
\hline S06K001008 & Pall input \\
S06K001011 & Pall 10- $\mu \mathrm{m}$ filtrate \\
S06K001008 & Keystone input \\
S06K001012 & Keystone 10- $\mu \mathrm{m}$ filtrate
\end{tabular}

The samples were submitted in 1-L brown glass bottles and were analyzed as-received (i.e., without preconcentration of any suspended solids present).

\section{PSD MEASUREMENTS}

\section{Instrumentation}

Measurements of the PSDs of solids suspended in the test samples were performed using the Horiba L.A-910 Laser Scattering Particle Size Distribution Analyzer ${ }^{15}$ in hood 2 in room $1 F$ of 222-S. The LA-910 is an ensemble type, light-scattering-based PSD analyzer; it is not a sensingzone or image-analysis type of instrument where measurements or observations of individual particles are made. The composite light-scattering pattern created when a large number of sample particles scatter the light in the focused beam(s) of the analytical probe(s) is measured. Analyzer software, using iterative algorithms based on Mie Scattering Theory, then creates a virtual population of optically isotropic, compositionally homogeneous, spherical particles with a distribution of diameters that would, given the same experimental parameters, generate a similar light-scattering pattern. The reported particle sizes are the diameters of these spherical particles, i.e., equivalent spherical diameters. The frequencies of occurrence of particles of various sizes in the hypothetical populations are weighted according to the volumes of the spherical particles.

The LA-910 analyzer uses dual light sources: a helium-neon laser $(\lambda=632.8 \mathrm{~nm})$ and a $40-W$, tungsten-halogen, blue-filtered lamp $(\lambda=450 \mathrm{~nm})$. The dual light sources and physical design of the detector array allow measurement of PSDs for samples with particles ranging from $0.02 \mu \mathrm{m}$ to $1020 \mu \mathrm{m}$ in equivalent spherical diameter.

\footnotetext{
${ }^{15}$ Horiba is a registered trademark of Horiba, Ltd. Corporation Japan, Kyoto, Japan.
} 
The LA-910 analyzer was operated in flow cell mode for the PSD measurements. In this mode, a dilute suspension of sample solids is continuously circulated through the analyzer measuring loop during PSD measurements. Key components in the loop include the following.

Sample Tank: Sample solids and suspension liquid are introduced into a stainless-steel sample tank (maximum volume $\approx 28 \mathrm{~mL}$ ). Specimen suspensions were limited to $200 \mathrm{~mL}$ to minimize potential contamination of the sample chamber. Suspensions enter the measurement loop from the bottom of the tank.

Stirrer: A three-bladed mechanical stirrer in the sample tank assists in suspending the sample solids in the suspension liquid and is critical in introducing a uniform sample suspension into the flow loop. The stirrer speed is adjustable in seven step settings, ' 1 ' through ' 7 '. In distilled water, a stirrer setting of ' 6 ' represents a stirring speed of $\approx 000$ revolutions/minute.

A stirrer speed setting of ' 2 ' was used for these measurements. Tests have shown that this stirrer speed is the minimum required to effectively sample spherical particles with density $\approx .5 \mathrm{~g} / \mathrm{cm}^{3}$ and with diameters up to $350 \mu \mathrm{m}$ in aqueous suspensions.

Ultrasonic Generator: The sample tank is also the chamber of a low-power $(40 \mathrm{~W}, 39 \mathrm{kHz})$ ultrasonic bath. This ultrasonic bath is provided to facilitate dispersion of sample particulates in the suspension liquid. The power of the bath is fixed. The operator may select whether or not to activate the ultrasonic generator. If activated, the operator may adjust the time the bath operates before the light-scattering measurement begins and the length of any delay period between termination of the ultrasonic treatment and initiation of the PSD measurement. The operator may also elect to continue ultrasonic treatment during the light-scattering measurement. For brevity, ultrasonic treatment of samples hereafter is referred to as "sonication."

Circulation Pump: Located immediately downstream from the sample tank, a variable-occlusion peristaltic pump circulates the sample slurry through the analyzer measurement loop. The pump speed is adjustable in seven step settings, ' 1 ' through '7'. A pump speed setting of ' 4 ' was used for these measurements. The discharge volume at this pump speed setting is $\Rightarrow \mathrm{mL} / \mathrm{s}$ using Tygon ${ }^{16}$ tubing with an internal diameter of $4.8 \mathrm{~mm}$.

The occlusion of the Masterflex ${ }^{17}$ peristaltic pump head is adjusted so that the purmp tubing is not totally compressed (occluded) at any point of the rotor rotation. Performance tests using this occlusion setting and various pump and stirrer speed combinations have shown that a stirrer speed of ' 2 ' combined with a pump speed of ' 4 ' is the minimum combination required to satisfactorily measure the PSD of a certified standard containing soda-lime glass microspheres $\left(\rho=2.4\right.$ to $\left.2.5 \mathrm{~g} / \mathrm{cm}^{3}\right)$ with diameters ranging from $50 \mu \mathrm{m}$ to $350 \mu \mathrm{m}$-Whitehouse Scientific ${ }^{18}$ standard PS223.

\footnotetext{
${ }^{16}$ Tygon is a registered trademark of Norton Company, Worcester, Massachusetts.

${ }^{17}$ Masterflex is a registered trademark of the Cole-Parmer Instrument Company, Vemon Hills, Illinois.

${ }^{18}$ Whitehouse Scientific, Waverton, Chester, England.
} 


\section{RPP-RPT-30093, Rev. 0}

Measurement Cell: The flow cell is located immediately downstream from the circulation pump. The two optical windows of the cell are Tempax ${ }^{19}$ glass (with a nonreflective coating on the exterior surfaces) and define an interior specimen cavity with dimensions of $70 \times 45 \times 3.5 \mathrm{~mm}$ $(H \times W \times D)$. The analytical light probes traverse paths through the depth of the cell perpendicular to the cell windows. The sample suspension enters at the bottom of the measurement cell, exits at the top of the cell, and returns to the sample tank.

\section{Specimens}

The specimens analyzed were 200 -mL portions of the test water samples. The supplied test samples were first thoroughly mixed by inversion and rotation of the original bottles for a minimum of 3 minutes. Then, as quickly as possible, $\approx 5 \mathrm{~mL}$ was poured into a (non-wetting plastic) transfer beaker. This process was repeated two additional times with an additional 30 seconds of mixing between each. The $200-\mathrm{mL}$ specimen was then poured from the transfer beaker into the analyzer sample tank.

Ten drops of an aqueous solution of sodium hexametaphosphate $\left[\left(\mathrm{NaPO}_{3}\right)_{6}\right]$ were added to the test specimens, as a chemical dispersant, prior to PSD measurements. The final concentration of $\left(\mathrm{NaPO}_{3}\right)_{6}$ was $<0.05 \mathrm{wt} \%$.

\section{Measurements}

Particle size distribution measurements were made on two specimens ( $A$ and $B$ ) withdrawn from each test sample. The PSD measurement on each specimen was a set of two sequential PSD runs.

The procedure for completing a set of PSD runs on a single specimen was as follows:

1. A large volume of laboratory reagent water was filtered through a $0.2-\mu \mathrm{m}$ membrane filter immediately prior to the PSD measurements.

2. Approximately $175 \mathrm{~mL}$ of filtered water and ten drops of $\left(\mathrm{NaPO}_{3}\right)_{6}$ solution were added to the analyzer sample tank.

3. The pump speed was set to ' 5 ' and the stirrer speed to ' 2 ' and the blank charge was sonicated for $\mathbf{2}$ minutes. [This treatment ensures the measurement loop is free from particles and bubbles.]

4. The purnp speed was set to ' 4 ' and the stirrer speed to ' 2 ' and a blank measurement was completed.

5. The blank water charge was drained from the analyzer.

6. $200 \mathrm{~mL}$ of test sample (Specimen $\mathrm{A})$ and ten drops of $\left(\mathrm{NaPO}_{3}\right)_{6}$ solution were added to the analyzer sample tank.

7. Run 1 analyzer settings (Table 1) were established and the specimen charge was allowed to stir and circulate for 15 seconds.

\footnotetext{
${ }^{19}$ Tempax is a registered trademark of Schott Glaswerkes, Mainz, Germany.
} 


\section{RPP-RPT-30093, Rev. 0}

8. The Run 1 measurement sequence was started.

9. When Run 1 was complete, the presence of a saved data file was verified, Run 2 analyzer settings were established, and the Run 2 measurement sequence was started. (The estimated time from the end of Run 1 to the initiation of Run 2 is $\approx 5$ seconds.)

10. When Run 2 was complete, the presence of a saved data file was verified.

11. Specimen A was drained from the analyzer. The analyzer was flushed with $=100-\mathrm{mL}$ of filtered, reagent water which was drained to waste.

12. A second $200-\mathrm{mL}$ portion of test sample, Specimen $\mathrm{B}$, and ten drops of $\left(\mathrm{NaPO}_{3}\right)_{6}$ solution were added to the analyzer sample tank. Steps 6-10 were repeated.

13. Specimen $B$ was then drained from the analyzer. The analyzer was flushed with reagent water until the light-scattering pattern returned to a particulate-free profile.

The analyzer settings and sequence times that were used in each PSD run are presented in Table 1.

Table 1. Particle Size Distribution Analyzer Measurement Run Settings.

\begin{tabular}{|c|c|c|c|c|c|c|}
\hline$\cdots \quad \vdots$ & Sample & & PSI & ensurentian & an & \\
\hline 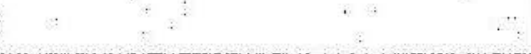 & Load-In & 1 & 2 & 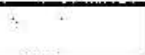 & & \\
\hline Analyzer settlings $\quad:$ & $\therefore \quad \therefore$ & $\because \quad \because$ & + & $\cdot$ & 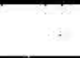 & \\
\hline Pump (circulation) speed setting & 4 & 4 & 4 & - & - & 一 \\
\hline Stirrer (agitation) speed setting & 2 & 2 & 2 & - & - & 一 \\
\hline Premeasurement working & $\therefore$ & 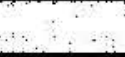 & $\because$ & $\ldots$ & & \\
\hline Work time (seconds) & 15 & 10 & 120 & 一 & - & - \\
\hline Ultrasonics $\mathrm{ON}$ & NO & NO & YES & - & - & - \\
\hline Pre-measurement wait (seconds) & $\mathrm{n} / \mathrm{a}$ & 0 & 10 & - & - & - \\
\hline Measurement & $\therefore$ & $\therefore \quad \vdots$ & $\therefore$ & $\therefore$ & & \\
\hline Measure cycles (laser/larmp) ${ }^{a}$ & $\mathbf{n} / \mathbf{a}$ & $90 / 18$ & $90 / 18$ & - & - & - \\
\hline Sonication during measure & $\mathbf{n} / \mathbf{a}$ & NO & No & 一 & - & - \\
\hline Total sonication time (mimutes) & 0 & 0 & 2 & - & - & - \\
\hline Total time (minutes:seconds) ${ }^{b}$ & $0: 15$ & $1: 55$ & $5: 50$ & - & - & - \\
\hline
\end{tabular}

"A composite measurement combining 90 readouts of detectors while illuminating sample with the He-Ne laser and 18 readouts while illuminating the sartiple with the blue-filtered lamp. Total measurement time $\$ 0$ sec.

${ }^{b}$ Cumulative measurement time. Setting up and initiating each PSD run takes $\approx 5$ sec based on previous measurement experience.

\section{Optical Model}

Conversion of the light-scattering pattems measured by the analyzer to PSDs requires input of a relative refractive index--

$$
\mathrm{RRI}=\text { Refractive index (particles) / Refractive index (liquid medium). }
$$


The accuracy of this input becomes increasingly important as the diameters of the particles become smaller than $\approx 5 \mu \mathrm{m}$ (ISO 13320-1).

The complex refractive index $(\mathrm{N})$ of a substance is defined as

$$
\mathrm{N}=\boldsymbol{n}-\boldsymbol{k i},
$$

where the real index, $n$, represents the degree of refraction of light in the material. The complex (or imaginary) part of the index, $k \mathrm{i}$, is directly proportional to the degree of attenuation (primarily by absorption) of the probe light beam(s) by a material. Transparent materials have small extinction coefficients $(k)$; opaque and/or highly colored materials have larger coefficients.

In practice, it is assumed that a suspension liquid that strongly absorbs at the wavelength(s) of the analytical probes will not be used and that minor absorption by the liquid will be accounted for by blank measurements. The RRI value actually input is

$$
\mathrm{RRI}=\left(n_{\mathrm{p}} / n_{\mathrm{m}}\right)-k_{\mathrm{p}} \mathrm{i} .
$$

The suspension liquid was assumed to be pure water with a real refractive index, $n_{\mathrm{m}}=1.333$ (at $\lambda=589.3 \mathrm{~nm})$.

The sample solids were (arbitrarily) assigned an index of refraction of $\mathrm{N}_{\mathrm{p}}=1.60-0.10 \mathrm{i}$.

The RRI value input in the PSD calculations was

$$
\mathrm{RRI}=\left(n_{\mathrm{p}} / n_{\mathrm{m}}\right)-k_{\mathrm{p}} \mathrm{i}=(1.60 / 1.333)-0.1 \mathrm{i}=1.20-0.10 \mathrm{i} \text {. }
$$

[If the client has input suggesting that an alternate RRI value would be more appropriate or desirable, PSDs can be recalculated using revised value(s) without reanalysis of physical specimens.]

\section{DEVIATIONS}

Ideally, particle concentration in sample suspensions should be above a minimum level required to produce an acceptable signal-to-noise ratio. In the LA-910 analyzer this concentration corresponds to a reduction in \%-transmission to about 95\% (reduction in transmission of the probe light beam through the suspension by $5 \%$ relative to the particle-free suspension liquid). To avoid multiple scattering, the solids concentration should be below a level that corresponds to about $65 \%$-transmission for particles larger than $20 \mu \mathrm{m}$ and about $85 \%$-transmission for smaller particles (ISO 13320-1).

The four test samples all had very small concentrations of solids. Values of light transmission (\%-T) observed were as seen in Table 2. 
Table 2. Observed \%-Transmission Values During PSD Measurements.

\begin{tabular}{|l|c|c|c|c|}
\hline \multirow{2}{*}{} & \multicolumn{2}{|c|}{ Laser \%-T } & \multicolumn{2}{c|}{ Lamp \%-T } \\
\cline { 2 - 5 } & Ran & Sonicated & Ran 1 & Sonicated \\
\hline Reagent water & 100 & 100 & 100 & 100 \\
\hline Pall Input & 96.4 & 96.8 & 95.4 & 94.9 \\
\hline Pall 10- $\mu$ m filtrate & \multicolumn{2}{|c|}{ Not measurable } & \multicolumn{2}{c|}{ Not measurable } \\
\hline Keystone input & 98.4 & 98.8 & 98.0 & 97.9 \\
\hline Keystone 10- $\mu \mathrm{m}$ filtrate & 99.7 & 100 & 99.9 & 100 \\
\hline
\end{tabular}

\%-Transmission values for the He-Ne laser are most sensitive to the presence of particles greater than a few micrometers in diameter; \%-Transmission values at the effective wavelength of the larnp source are most strongly effected by particles smaller than a few micrometers in diameter.

The solids concentration in the Pall $10-\mu \mathrm{m}$ filtrate sample was so low that the analyzer was not able to distinguish the specimen from the reagent water blank and PSD measurements were not possible.

\section{PSD MEASUREMENT RESULTS}

The results of the light-scattering-based PSD measurements are presented in this section. As previously noted, measurements on the test samples were made in duplicate. For each sample, the data files for corresponding PSD runs from the duplicate specimens were combined into 'average' data files. The PSD histograms, \%-undersize curves, and numerical data derived from these average data files are presented here. [Complete transcripts of all PSD data can be provided on request.]

The scattered-light patterns measured by the LA-910 analyzer are directly related to the volumes of small particles and the cross-sectional area of larger particles. The primary analyzer outputs are PSDs with frequencies of occurrence weighted according to the volumes of the scattering particles. The analyzer software allows these primary distributions to be recalculated as area-, length-, or number-based distributions. These converted distributions are obtained by reweighting the original, partially processed, volume-based data using the appropriate power of the particle diameters (d) and then renormalizing the resulting distributions. For example, numberbased PSDs are obtained by applying weighting factors proportional to $1 / \mathrm{d}^{3}$ to the original volume-based PSD data. Particle size data derived from both the volume-based and the recalculated number-based PSDs are included.

Particle size distribution data for the test samples is based on standard-form distributions (as opposed to the "sharp-form" alternative in the analyzer algorithms). These distributions are generally characterized by broad, poorly resolved features but are appropriate for the calculation of PSDs of samples with unknown composition and morphology and/or a wide range of particle diameters.

All the PSD data presented are calculated using an RRI value of $1.20-0.10 \mathrm{i}$. 


\section{Histograms and \%-Undersize Curves}

The volume-based histograms and \%-undersize curves depicting the averaged results of the duplicate PSD measurements on the Pall input, Keystone input, and Keystone $10-\mu \mathrm{m}$ filtrate samples are presented in Figures 1, 2, and 3, respectively.

The volume-based histograms and cumulative curves of Figures 1 through 3 are plotted using a common particle diameter $(x$-axis) scale, $0.1 \mu \mathrm{m}-600 \mu \mathrm{m}$. No particulates with diameters $<0.1 \mu \mathrm{m}$ or $>600 \mu \mathrm{m}$ were observed in any calculated PSD for the test samples. To further facilitate comparison of the graphic data, all the volume-based, PSD histogram data are also plotted against a common frequency-\% (y-axis).

The recalculated, number-based PSD histograms and \%-undersize curves depicting the averaged results of the duplicate PSD measurements on the Pall Input, Keystone Input, and Keystone $10-\mu \mathrm{m}$ Filtrate samples are presented in Figures 4,5 and 6, respectively. As for the volumebased data, the number-based histograms and cumulative curves of Figures 4-6 are plotted using common particle diameter $(0.1 \mu \mathrm{m}-10 \mu \mathrm{m})$ and frequency- $\%$ scales.

\section{Cumulative \%-Undersize Data}

The particle diameters associated with five pre-selected points on the cumulative \%-undersize curves describing the volume-based PSDs for the Pall input, Keystone input, and Keystonc $10-\mu \mathrm{m}$ filtrate samples are presented in Table 3. The default data sets generated by the LA-910 analyzer consist of 80 , logarithmically-spaced particle-diameter bins that are populated with occurrence frequency data. A software option allows this process to be reversed: "Diameter-on$\%$ " occurrence frequency values are pre-selected and then associated with particle diameters extracted from the calculated PSDs. The particle diameters associated with 10-, 25-, 50-, 75-, and $90 \%$-undersize selections are presented in the table. The $50 \%$-undersize values are, by definition, the median particle diameters of the PSDs.

The number-based, \%-undersize data extracted from the averaged PSD measurements is presented in Table 4. 
Figure 1. Volume-based Particle Size Distributions of Pall Input Sample.

(Average of duplicate measurements.)

(a) Run 1-Ultrasonic Time: None

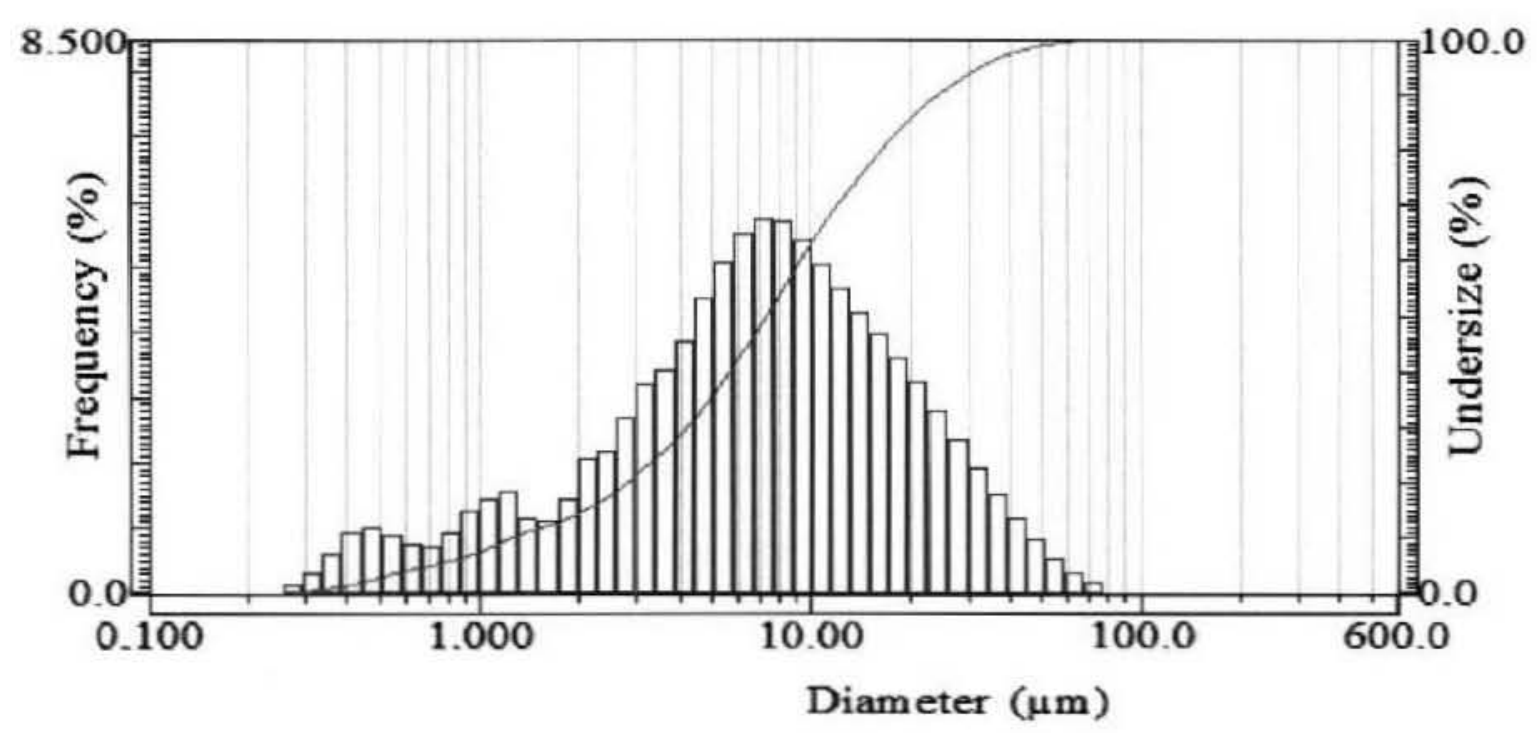

(b) Run 2 Ultrasonic Time: 2.0 minutes

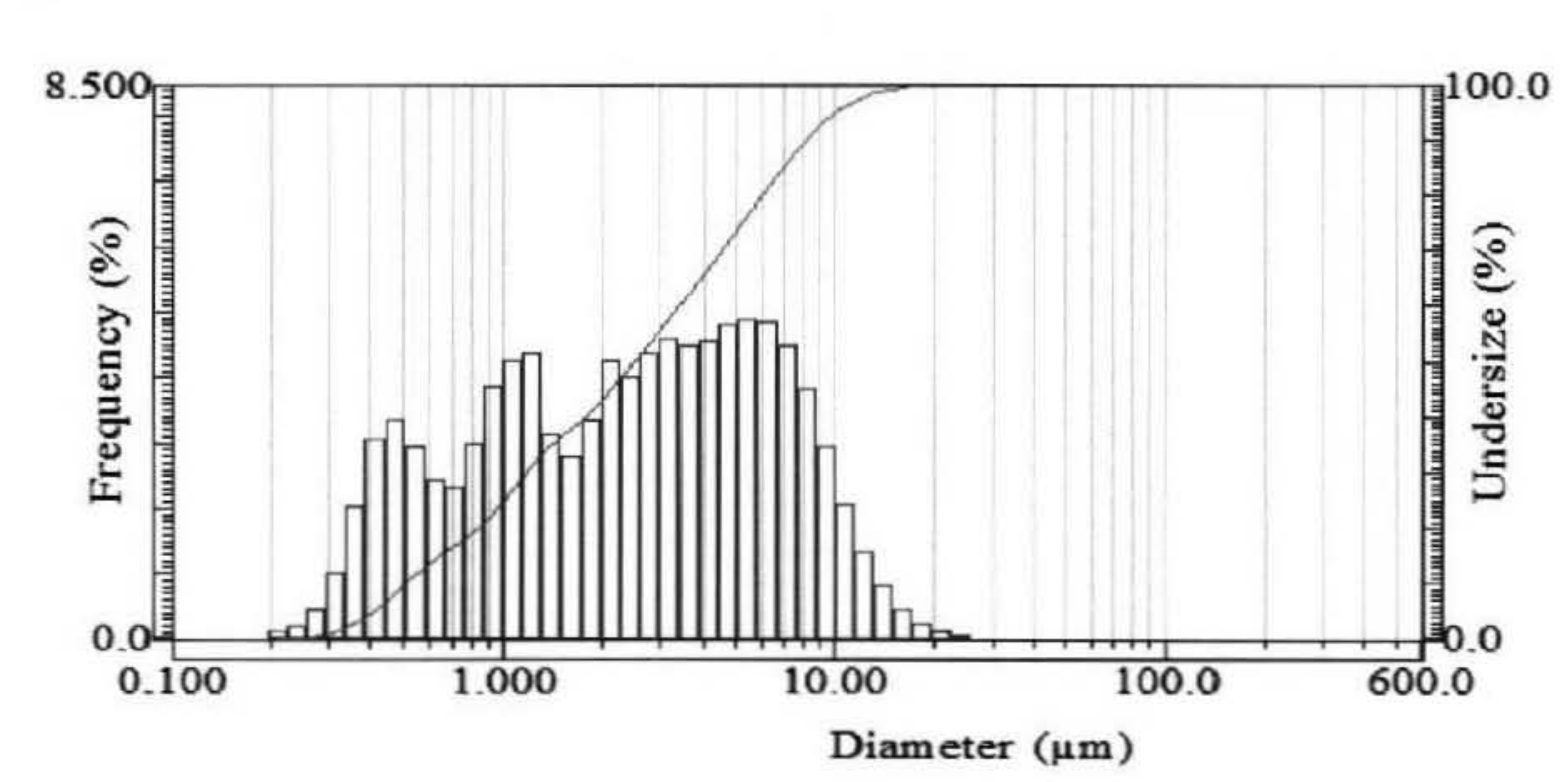




$$
\text { RPP-RPT-30093, Rev. } 0
$$

Figure 2. Volume-based Particle Size Distributions of Keystone Input Sample. (Average of duplicate measurements.)

(a) Run 1-Ultrasonic Time: None

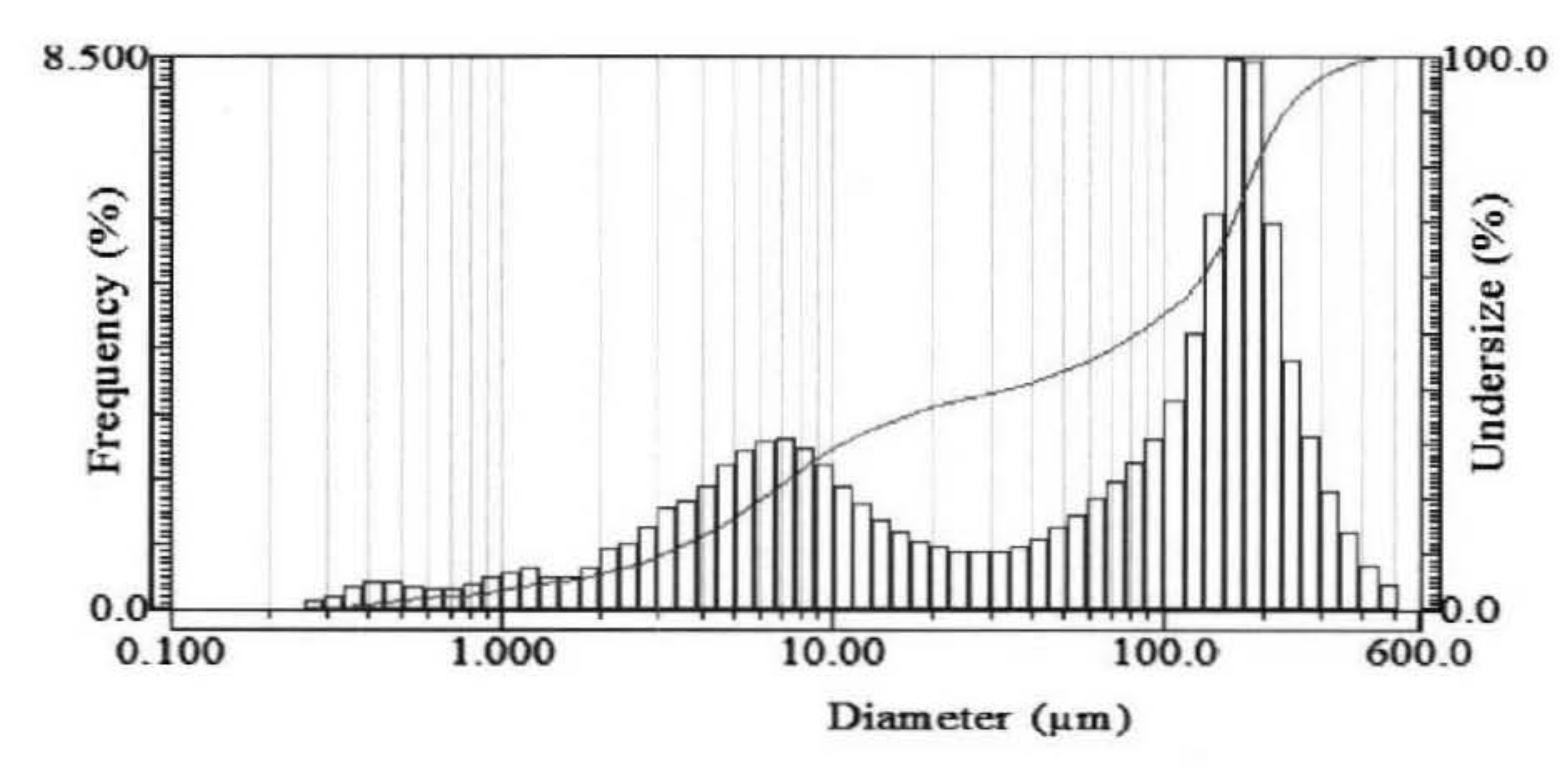

(b) Run 2 -Ultrasonic Time: 2.0 minutes

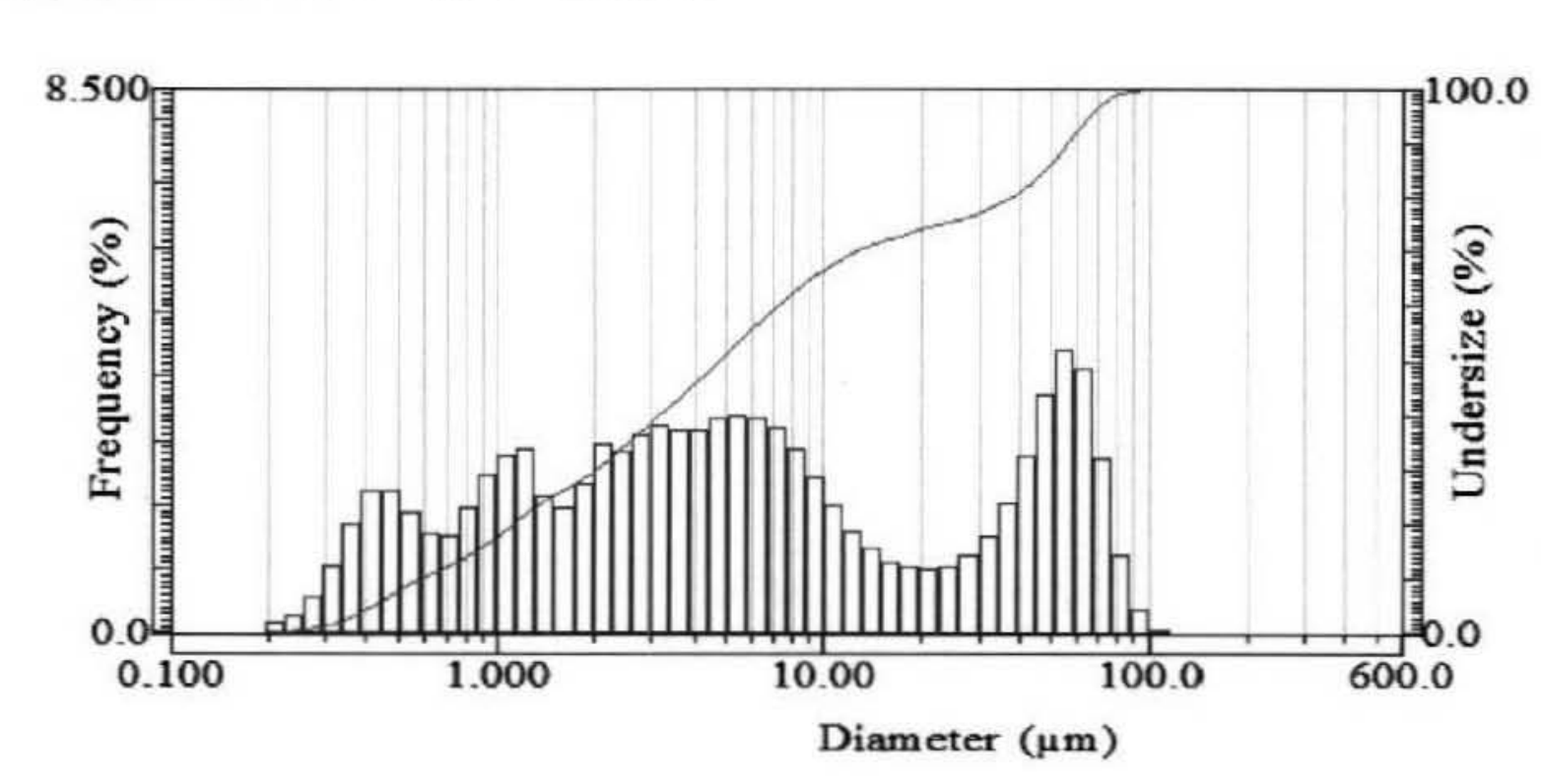

$$
\text { (Average of duplicate measurements.) }
$$

(a) Run 1-Ultrasonic Time: None 
RPP-RPT-30093, Rev. 0
Figure 3. Volume-based Particle Size Distributions of 10- $\mu$ m Keystone Filtrate.
(Average of duplicate measurements.)

RPP-RPT-30093, Rev. 0
Figure 3. Volume-based Particle Size Distributions of 10- $\mu$ m Keystone Filtrate.
(Average of duplicate measurements.)

(a) Run 1-Ultrasonic Time: None

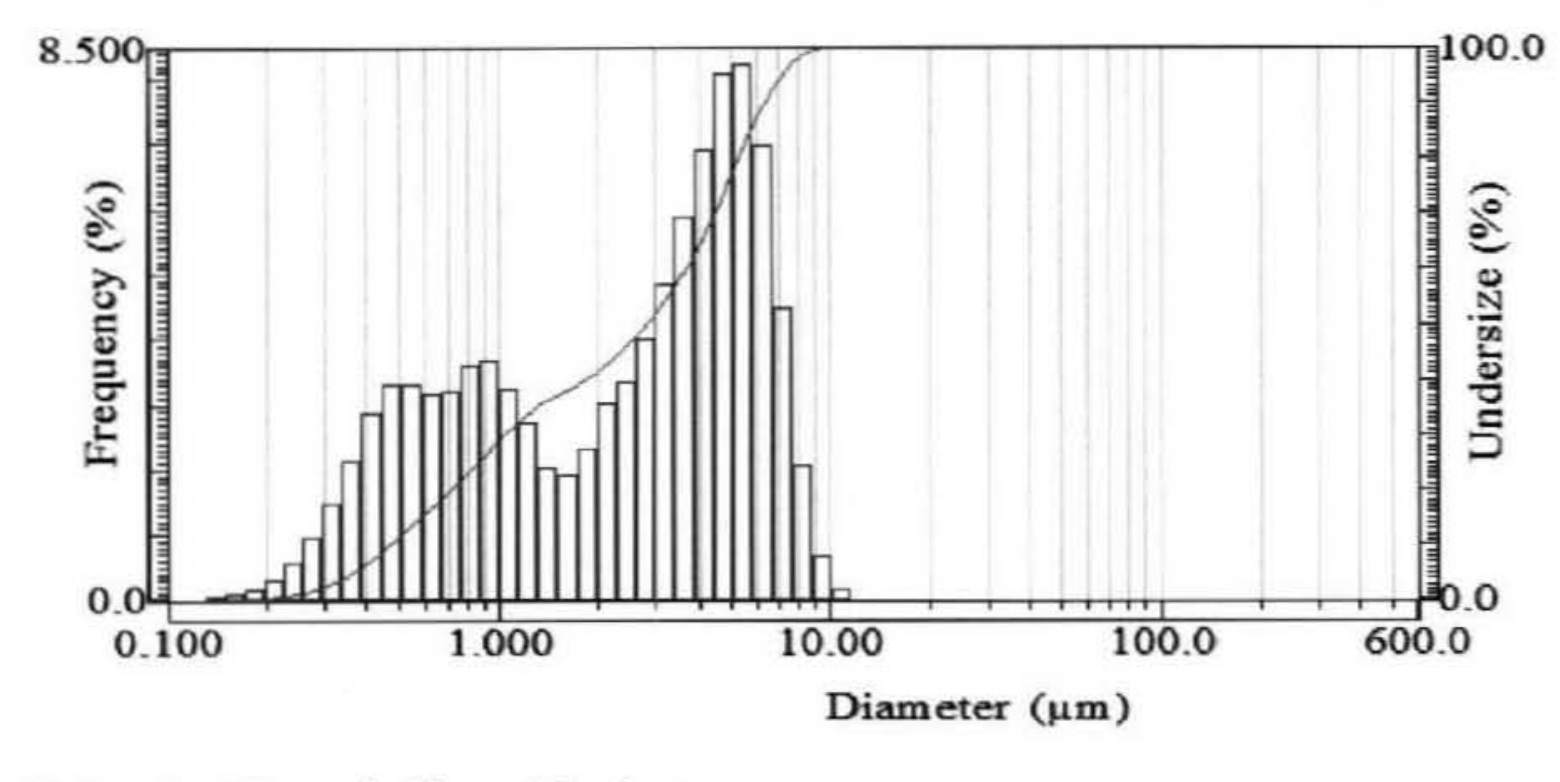

(b) Run 2-Ultrasonic Time: 2.0 minutes

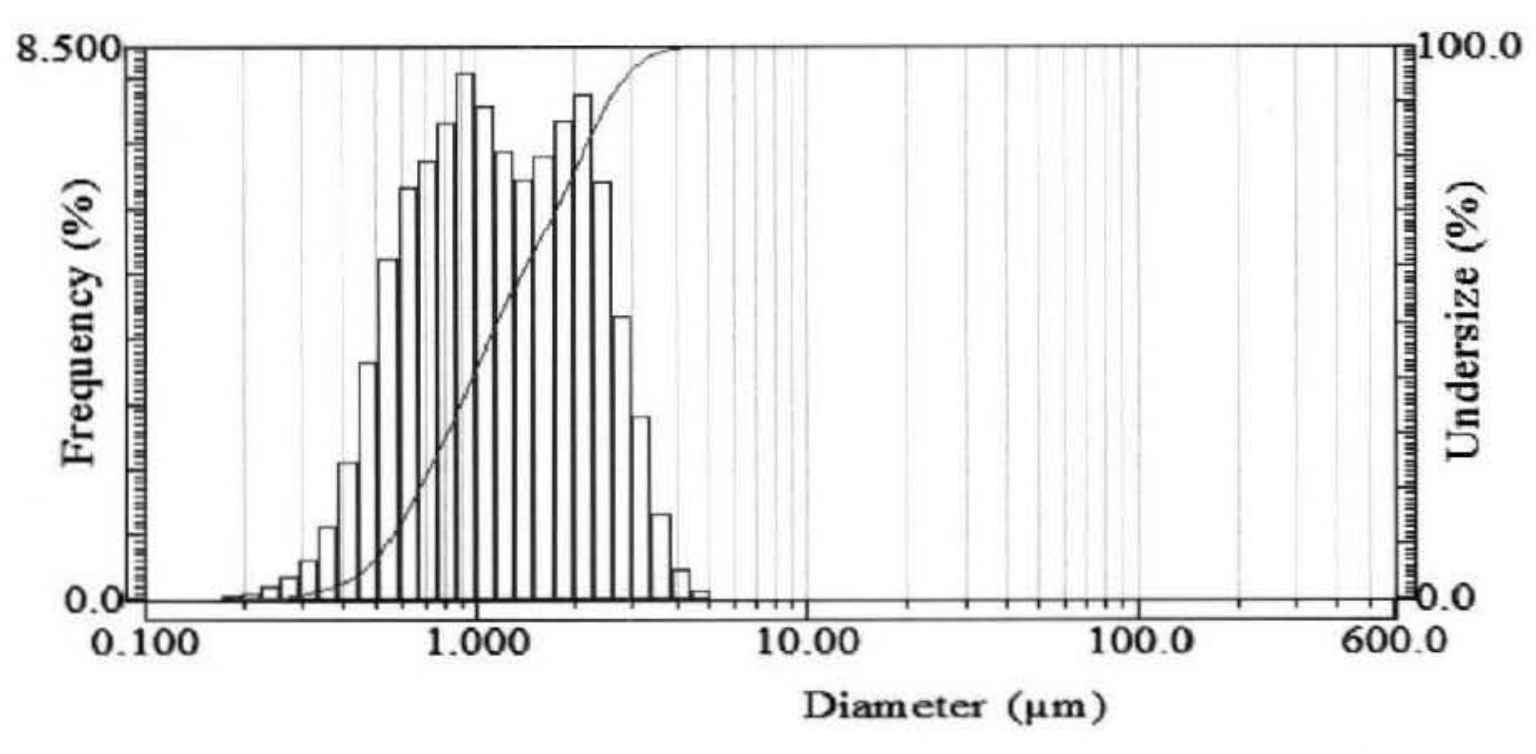

Diameter $(\mu \mathrm{m})$

rence

.
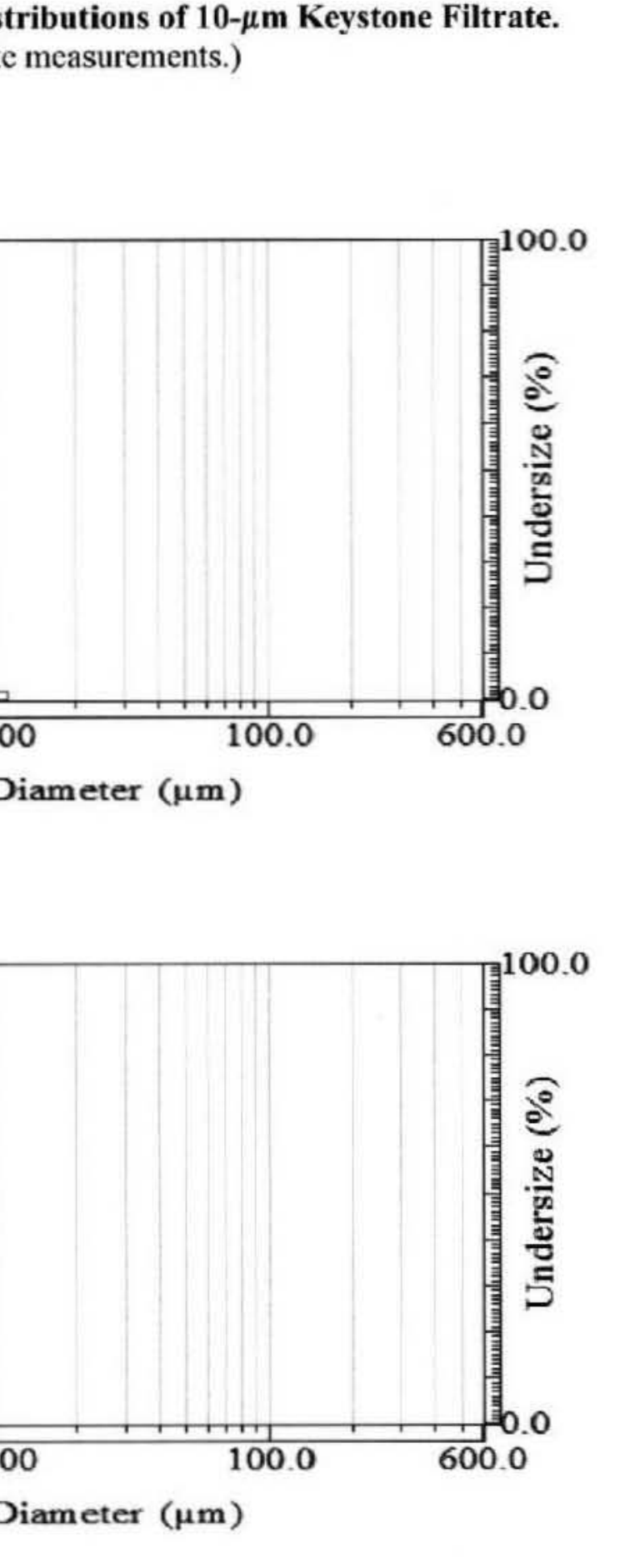


$$
\text { RPP-RPT-30093, Rev. } 0
$$

Figure 4. Number-based Particle Size Distributions of Pall Input Sample.

(Average of duplicate measurements.)

(a) Run 1-Ultrasonic Time: None

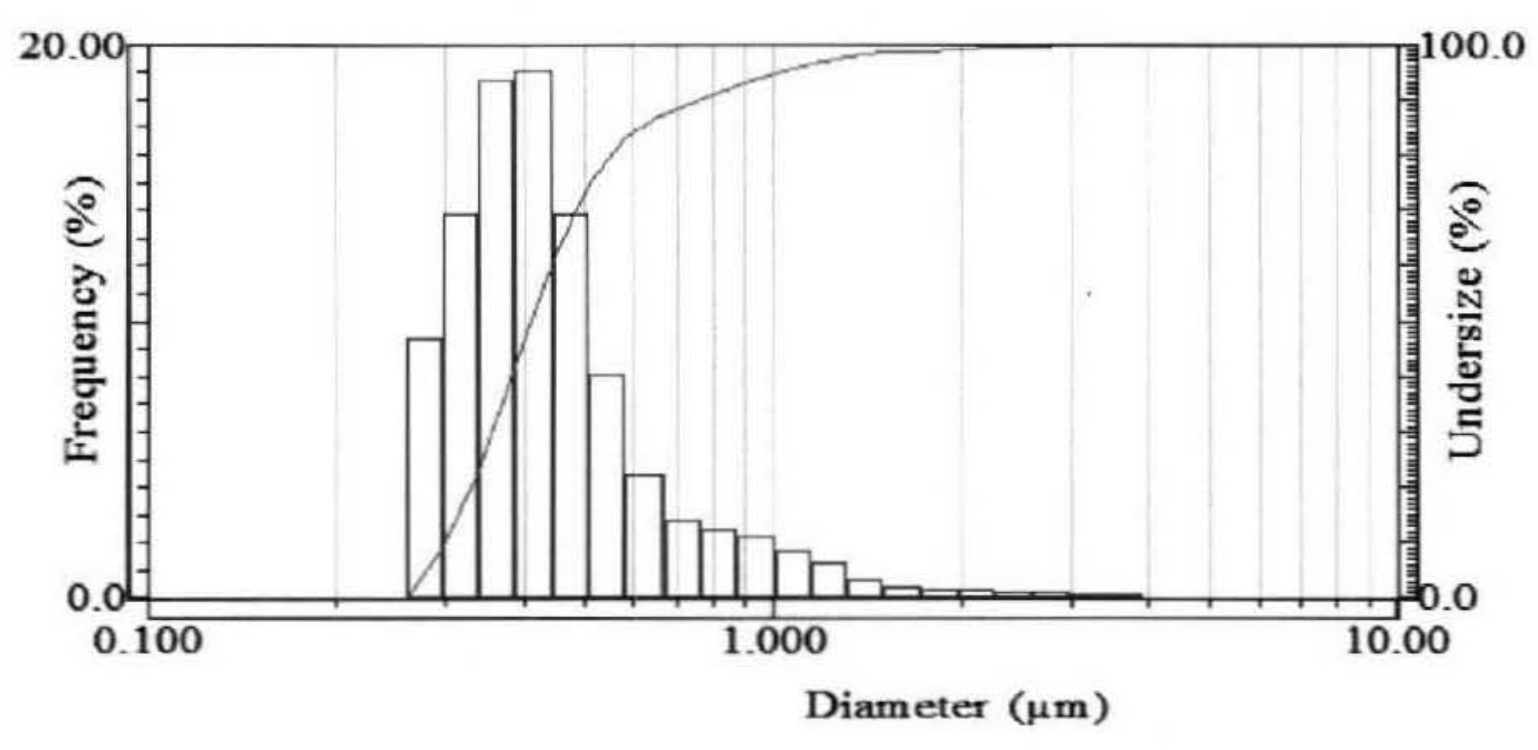

(b) Run 2-Ultrasonic Time: 2.0 minutes

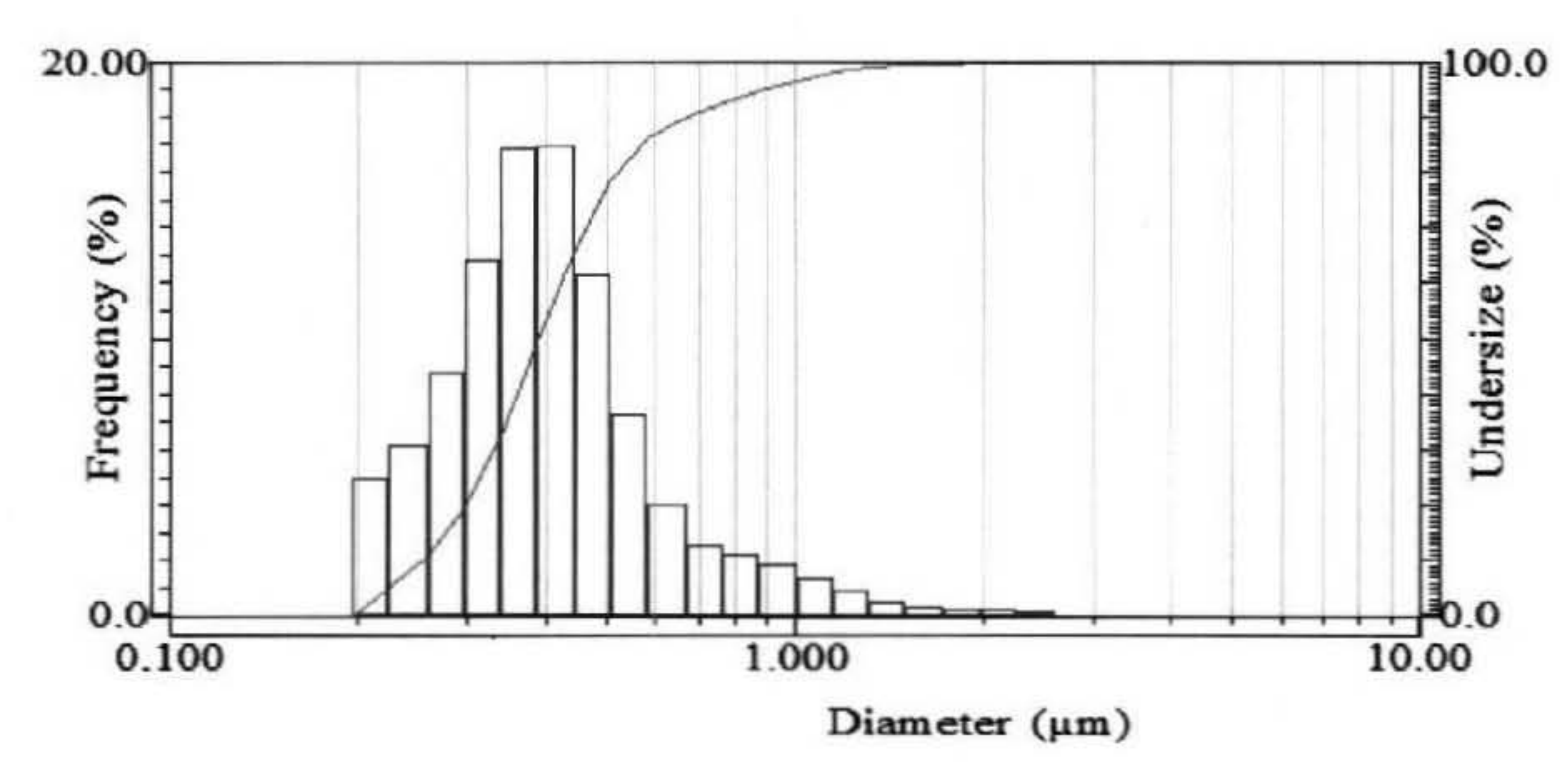

RPP-RPT-30093, Rev. 0

Diameter $(\mu \mathrm{m})$ 


$$
\text { RPP-RPT-30093, Rev. } 0
$$

Figure 5. Number-based Particle Size Distributions of Keystone Input Sample.

(Average of duplicate measurements.)

(a) Run 1-Ultrasonic Time: None

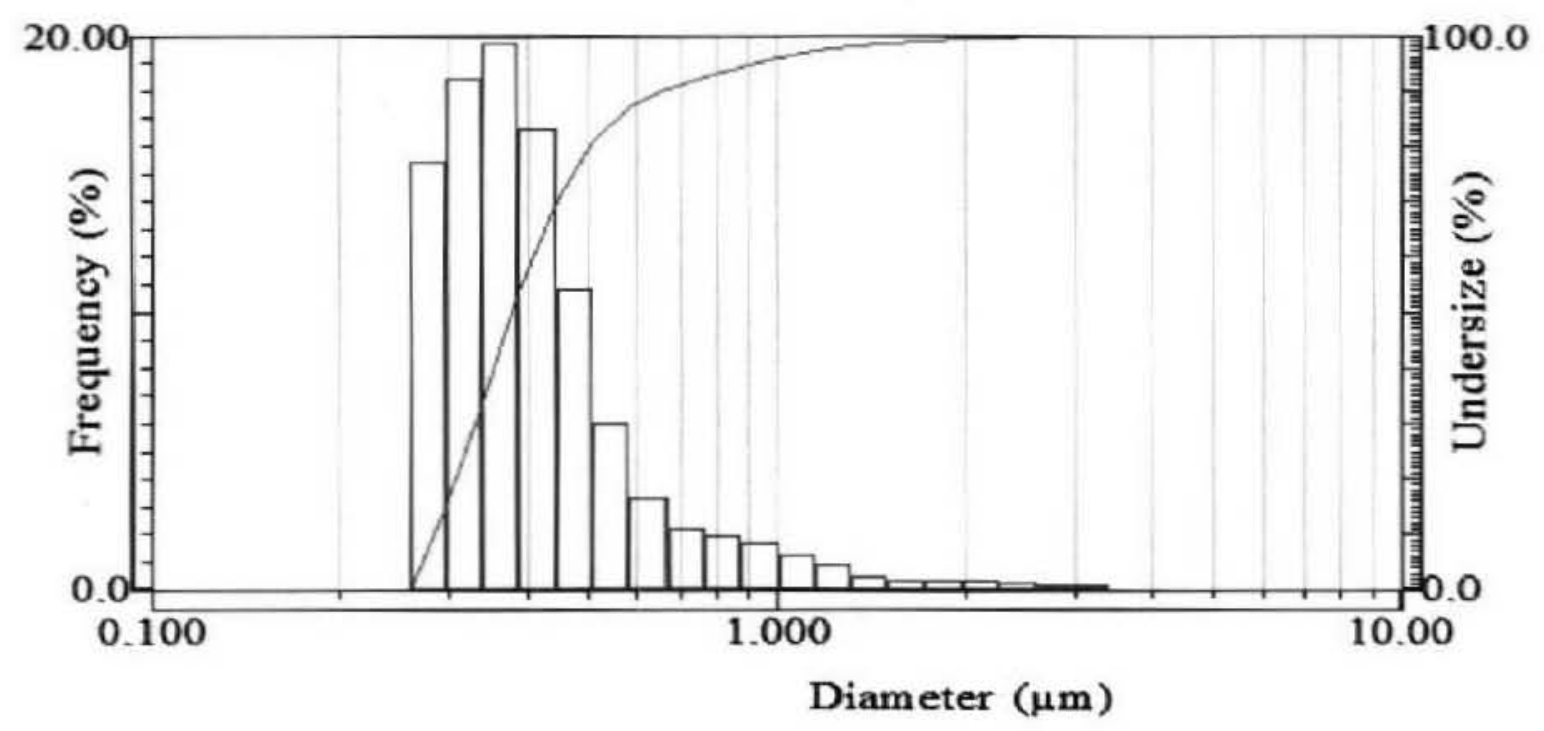

(b) Run 2-Ultrasonic Time: 2.0 minutes

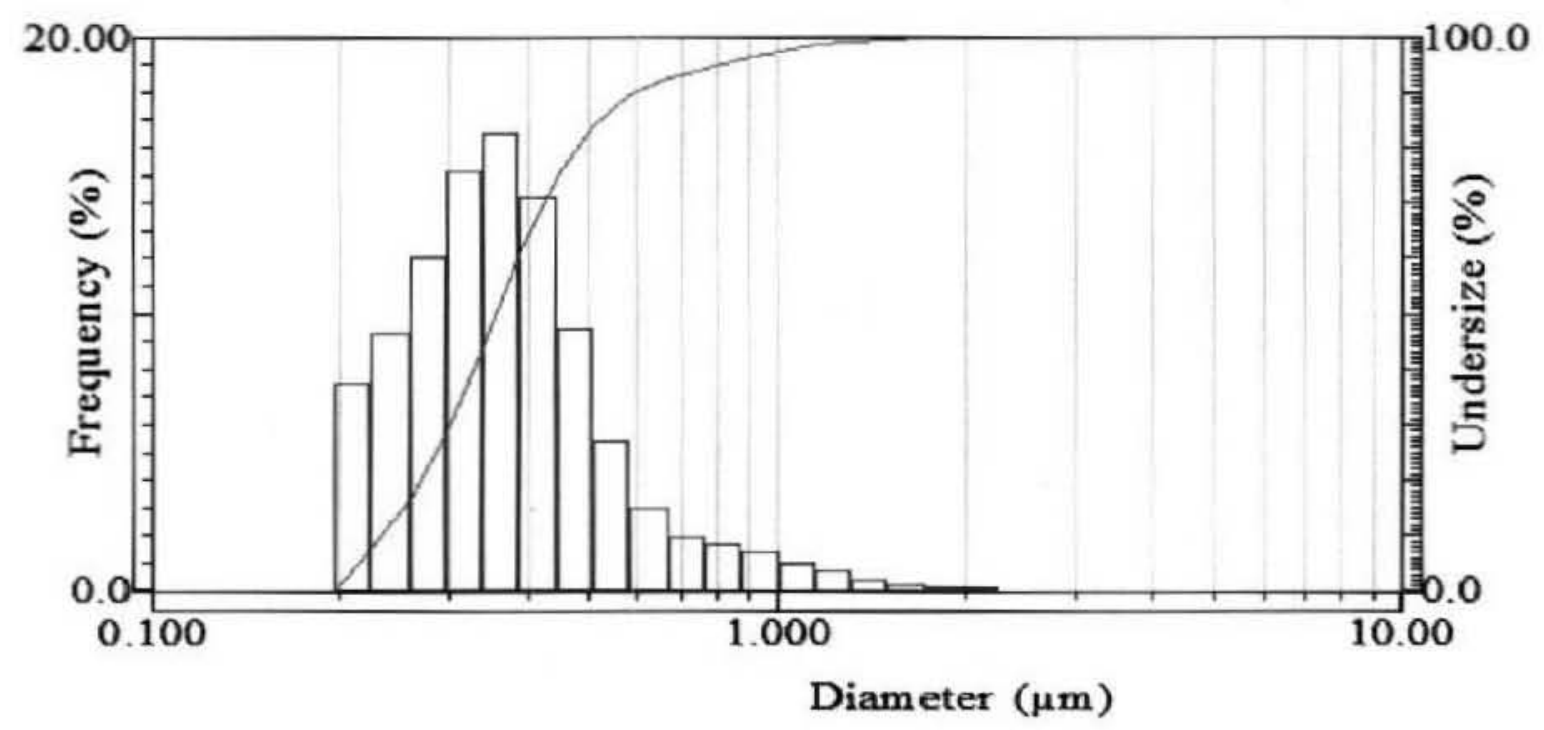




$$
\text { RPP-RPT-30093, Rev. } 0
$$

Figure 6. Number-based Particle Size Distributions of Keystone 10- $\mu \mathrm{m}$ Filtrate. (Average of duplicate measurements.)

(a) Run 1-Ultrasonic Time: None

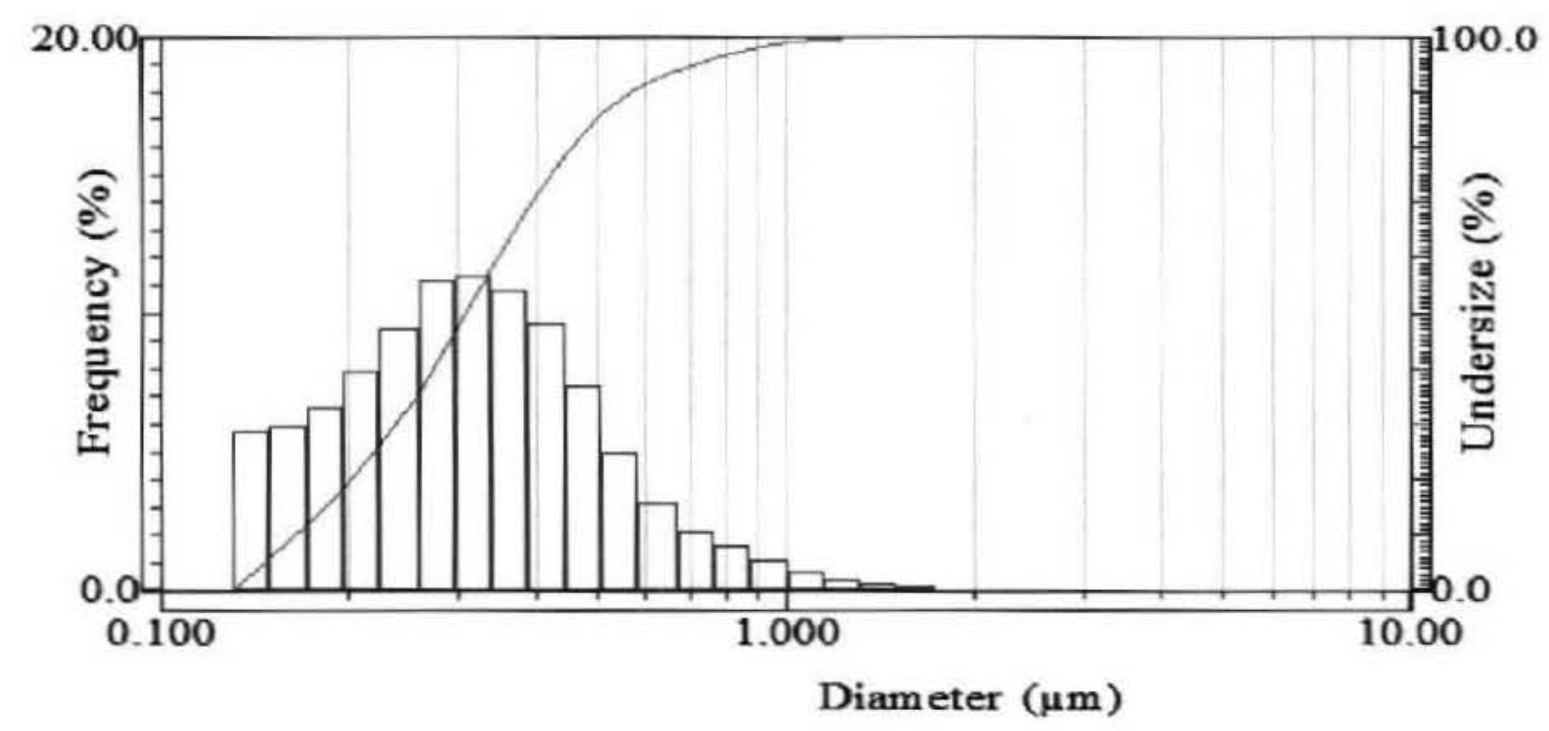

(b) Run 2 -Ultrasonic Time: 2.0 minutes

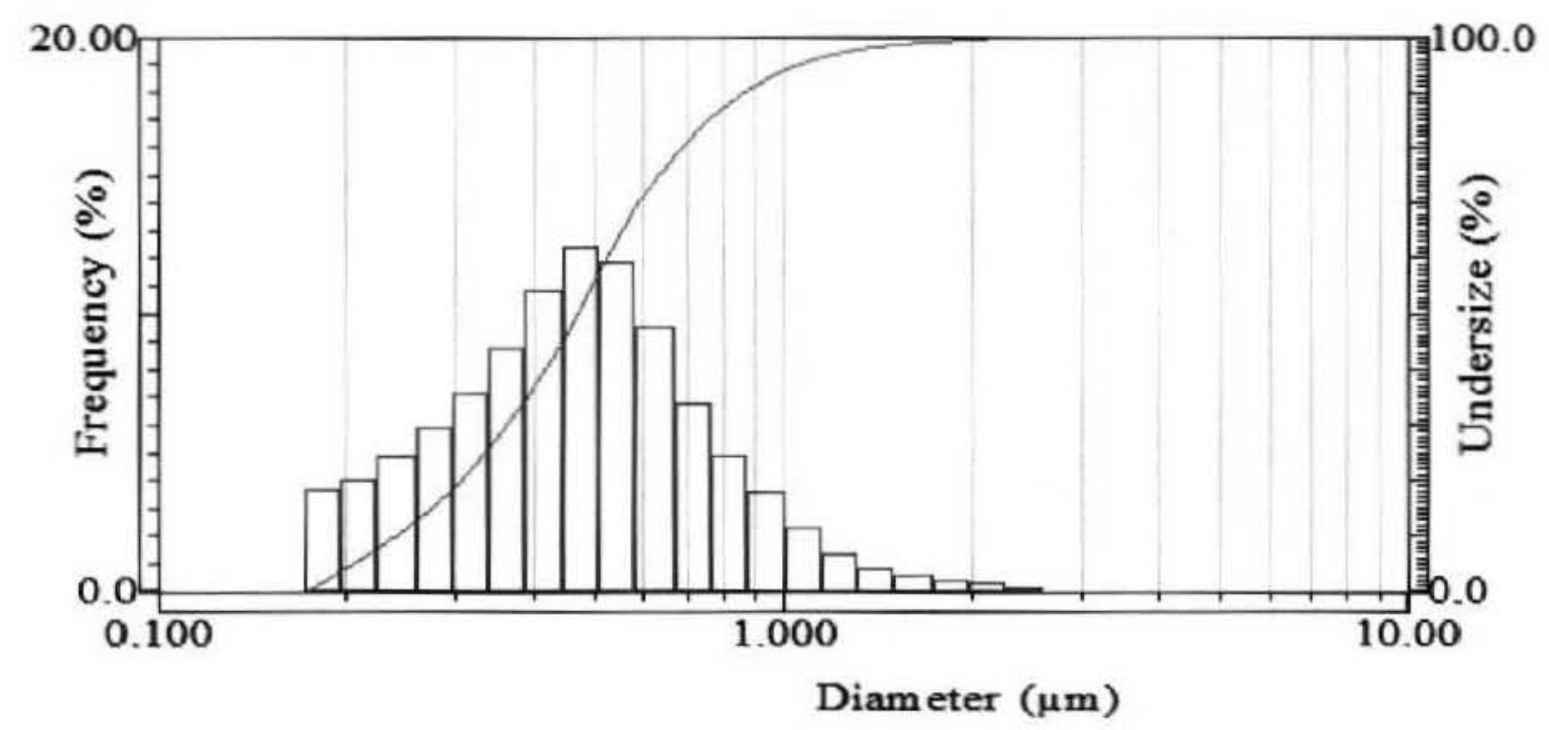


RPP-RPT-30093, Rev. D

Table 3. Volume-based, Cumulative \%-Undersize Data.

\begin{tabular}{|c|c|c|c|c|c|c|}
\hline & 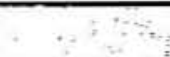 & \multicolumn{5}{|c|}{ Diameters of Partleles $(\mu \mathrm{m})$ at Cumulative \%-Undersize Cut Points } \\
\hline Sample & PSD Run & $10 \%$ & $\mathbf{2 5 \%}$ & $50 \%$ & $75 \%$ & $90 \%$ \\
\hline \multicolumn{2}{|c|}{ Pall Input Sample } & - & - & - & - & - \\
\hline \multirow[t]{3}{*}{ No sonication } & A1 & 1.26 & 3.5 & 7.2 & 13.6 & 23 \\
\hline & B1 & 1.26 & 3.5 & 7.3 & 14.5 & 26 \\
\hline & Average & 1.26 & 3.5 & 7.3 & 14.0 & 25 \\
\hline \multirow[t]{3}{*}{ Sonicated 2 minutes } & A2 & 0.51 & 1.04 & 2.6 & 5.6 & 8.9 \\
\hline & $\overline{B 2}$ & 0.50 & 0.98 & 2.4 & 5.0 & 7.6 \\
\hline & Average & 0.51 & 1.01 & 2.5 & 5.3 & 8.2 \\
\hline \multicolumn{2}{|c|}{ Keystone Input Sample } & - & - & - & - & - \\
\hline \multirow[t]{3}{*}{ No sonication } & Al & 2,8 & 6.9 & 59 & 155 & 229 \\
\hline & B1 & 3.5 & 9.9 & 123 & 185 & 237 \\
\hline & Average & 3.1 & 7.9 & 85 & 174 & 233 \\
\hline \multirow[t]{3}{*}{ Somicated 2 minutes } & A2 & 0.57 & 1.39 & 4.5 & 16.4 & 51 \\
\hline & B2 & 0.60 & 1.58 & 5.2 & 34 & 60 \\
\hline & Average & 0.58 & 1.48 & 4.8 & 23 & 56 \\
\hline \multicolumn{2}{|c|}{ Keystone $10-\mu \mathrm{m}$ Filtrate } & - & - & - & - & - \\
\hline \multirow[t]{3}{*}{ No sonication } & A1 & 0.56 & 1.00 & 3.0 & 4.9 & 6.3 \\
\hline & $\mathrm{B} 1$ & 0.39 & 0.74 & 2.7 & 5.0 & 6.4 \\
\hline & Average & 0.47 & 0.87 & 2.8 & 4.9 & 6.4 \\
\hline \multirow{3}{*}{ Sonicated 2 minutes } & A2 & 0.60 & 0.81 & 1.24 & 1.97 & 2.6 \\
\hline & $\mathrm{B} 2$ & 0.47 & 0.68 & 1.09 & 1.85 & 2.5 \\
\hline & Average & 0.53 & 0.74 & 1.17 & 1.92 & 2.5 \\
\hline
\end{tabular}

Table 4. Number-based Cumulative \%-Undersize Data.

\begin{tabular}{|c|c|c|c|c|c|c|}
\hline \multirow[b]{2}{*}{ Sample } & \multirow[b]{2}{*}{ PSD Run } & \multicolumn{5}{|c|}{ Diameters of Particles ( $\mu \mathrm{m}$ ) at Cumulative \%-Undersize Cut Points } \\
\hline & & $10 \%$ & $25 \%$ & $50 \%$ & $75 \%$ & $90 \%$ \\
\hline \multicolumn{2}{|l|}{ Pall Input } & - & - & - & - & - \\
\hline No sonication & Average & 0.30 & 0.34 & 0.41 & 0.51 & 0.76 \\
\hline Sonicated 2 minutes & Average & 0.25 & 0.31 & 0.39 & 0.49 & 0.67 \\
\hline \multicolumn{2}{|l|}{ Keystone Input } & - & - & - & - & - \\
\hline No somication & Average & 0.28 & 0.32 & 0.38 & 0.47 & 0.66 \\
\hline Sonicated 2 minutes & Average & 0.23 & 0.28 & 0.36 & 0.45 & 0.60 \\
\hline \multicolumn{2}{|c|}{ Keystone $10-\mu \mathrm{m}$ Filtrate } & - & - & - & - & - \\
\hline No sonication & Average & 0.17 & 0.22 & 0.31 & 0.42 & 0.57 \\
\hline Sonicated 2 minutes & Average & 0.24 & 0.34 & 0.47 & 0.63 & 0.87 \\
\hline
\end{tabular}




\section{PARTICLE SIZE DISTRIBUTION CAVEATS}

Light-scattering-based PSD measurements are based on several assumptions:

a. All sample particles are spherical.

b. All particles with diameters less than $\approx 25 \mu \mathrm{m}$ are compositionally and/or optically identical.

c. The optical properties of both the particles and the suspending medium are well known when samples contain particles with diameters less than $\approx 25 \mu \mathrm{m}$.

d. There is no interaction between light scattered from different particles (i.e., no multiple scattering phenomena).

Deviations from these assumptions will introduce some degree of error in the PSD measurements due to the inability of the deconvolution and inversion algorithms to account for the deviations.

It should also be reemphasized that the Horiba LA-910 is an ensemble type, light-scatteringbased PSD analyzer, not a sensing-zone or image-analysis type of instrument. Direct observation and/or measurement of individual particles are not made. The calculated PSDs are based, in part, on assumptions regarding the shapes and statistical properties of distributions that may not apply to the samples being measured.

\section{Measurement Range}

The results reported for the PSD analyses only apply to particles with diameters within the $0.02 \mu \mathrm{m}$ to $1020 \mu \mathrm{m}$ measuring range of the analyzer. The calculated PSDs are normalized so that the sum of the occurrence frequencies of particles within this range is always $100 \%$. This should not be taken to represent that particles with diameters $<0.02 \mu \mathrm{m}$ or $>1020 \mu \mathrm{m}$ were determined, by measurement, to be absent from the samples.

Visual observation during mixing and transfer of PSD specimens to the analyzer did not suggest that any discrete particles or strongly bound aggregates with dimensions approaching or exceeding $1020 \mu \mathrm{m}$ were present in any of the samples. The presence of particles with diameters $<0.02 \mu \mathrm{m}$ cannot be ruled out.

\section{Nonspherical Particles}

The light-scattering-based PSD data are presented in terms of an equivalent spherical diameterthe diameter of a spherical particle having the same light-scattering function as that assigned to the sample particle. By design, a nonlaminar, quasi-turbulent flow regime is maintained in the LA-910 flow cell. Under ideal conditions, the equivalent spherical diameter reported for any nonspherical particle would be derived from a combination of all cross-sectional diameters that a rapidly and randomly rotating particle could present to the probe light beams. The degree to which measurements on any significantly nonspherical component of a real, nonuniform sample actually achieves this ideal cannot be determined without undertaking an extensive study including both light-scattering-based and direct measurements of particle dimensions. This type of developmental program was not performed as part of these measurements. 
It is unknown whether the test samples contain significant amounts of nonspherical particles. The degree to which PSD measurements on these solids have yielded a meaningful, averaged spherical diameter is similarly unknown.

\section{Dispersion of Sample Particles}

Laser diffraction instruments cannot distinguish between scattering by single particles and scattering by clusters of primary particles forming an agglomerate or aggregate. Usually the measured particle size for agglomerates is related to the cluster size, but sometimes the size of the primary particles is reflected in the PSD as well (ISO 13320-1). Furthermore, no technique not based on direct observation of sample solids can distinguish between agglomerates that may exist in a sample in its native state and agglomerates that may form as a result of the measurement process (e.g., by introduction of the sample solids into a different liquid medium with different electrostatic properties). As a result, ensuring a good degree of dispersion prior to sample analysis is generally considered to be an important step to ensure reliable and reproducible size analysis (NIST 960-1, NIST Recommended Practice Guide: Particle Size Characterization).

In the current PSD measurements, Run 1 on each specimen was made under conditions where dispersion of sample solids was purposefully minimized. The uniform shift of the volume-based Run 2 PSDs to smaller particle diameters suggests that at least a portion of the initial solids were either loosely bound aggregates or fragile primary particles. The degree to which the particulates described by the Run 2 PSDs represent primary particles in the water samples is not known.

\section{Refractive Indexes}

In numerous cases, the results of a particle size analysis are only as good as the optical model chosen to interpret and convert the measured pattern of scattered light into a PSD (NIST 960-1). In particular, input of accurate refractive indexes of the sample solids and suspension liquid to the algorithms can be of critical importance.

When particle diameters are much larger than the wavelength of the light probe(s), scattering is effectively described as Fraunhofer diffraction and is independent of the optical properties of the sample material. To describe the scattering of light by smaller particles (down to diameters somewhat smaller than the light wavelength), use of Mie Scattering Theory is required. Application of Mie Theory requires that the complex refractive indexes of both the (assumed optically isotropic and spherical) particulate phase $\left(\mathrm{N}_{\mathrm{p}}\right)$ and the suspension liquid $\left(\mathrm{N}_{\mathrm{m}}\right)$ be known. This requirement is of increasing importance as the (a) particle diameters approach or become smaller than the wavelength(s) of the light scattered, (b) particles become increasingly transparent to the light probe(s), (c) particulates significantly absorb at the wavelength(s) of the light probe(s), and/or (d) refractive indexes of the liquid and solid phases approach one another.

The minimum particle size at which the Fraunhofer approximation holds varies depending on the actual solid-liquid system being measured. As a general rule (ISO 13320-1), the accuracy of the optical model data is not a significant concern for particles with diameters $>50 \mu \mathrm{m}$ and has only minor impact for particles with diameters as small as $18 \mu \mathrm{m}$ to $25 \mu \mathrm{m}$ for the 450 -nm and 
632-nm light sources employed in the LA-910 analyzer. The input of accurate optical data is of increasing importance as the diameters of sample particles become smaller than $25 \mu \mathrm{m}$ and is critical when particles diameters are less than $1 \mu \mathrm{m}$ to $2 \mu \mathrm{m}$.

The solids in the KE Basin test samples were arbitrarily assigned a refractive index of $\mathrm{N}_{\mathrm{p}}=1.60-0.10 \mathrm{i}$. There is no experimental or theoretical basis that supports this value.

A small change in the assigned RRI may cause a significant change in calculated PSDs. Also, the effect of the RRI on PSDs calculated for samples containing particles of diverse composition and morphology is, generally, quite complicated. Unfortunately, it is sometimes somewhat difficult, even for a single well-defined phase, to obtain an accurate value for the real index of refraction $\left(n_{\mathrm{p}}\right)$. Moreover, it is often very difficult to obtain an accurate value for the imaginary component $\left(k_{\mathrm{p}} \mathrm{i}\right)$ of the refractive index: absorption is often strongly dependent on wavelength, and the extinction coefficient can also be affected by surface structure of the particles (e.g., surface roughness) and intraparticle density heterogeneity. Indeed, it is common practice to determine appropriate values for the imaginary part (and often the real part also) of the refractive index using trial-and-error procedures of size determination using a microscopy-based technique, a light-scattering-based instrument, and samples of the solids to be measured.

\section{Specimen Size}

As was previously noted, none of the test water samples had a sufficient level of solids loading to allow PSD measurements to be completed within the desired $85 \%$ - to $95 \%$-transmission range. Indeed, the Pall 10- $\mu \mathrm{m}$ filtrate sample could not be distinguished from the reagent water blank and PSD measurements could not be completed. Quantitative accuracy of the PSD results for the Pall input, Keystone input, and Keystone 10- $\mu \mathrm{m}$ filtrate samples may be somewhat compromised.

Also, volume-based PSD measurements can be very sensitive to the presence of small numbers of large-diameter particles that can nevertheless represent a very large fraction of the sample particulate volume. For example, a single particle $50 \mu \mathrm{m}$ in diameter in a population of $1 \times 10^{6}$ particles, the balance of which are all $0.5 \mu \mathrm{m}$ in diameter, would have a number-based occurrence frequency of $0.0001 \%$. However, in a volume-based distribution the single $50-\mu \mathrm{m}$ particle would represent $50 \%$ of the particulate volume. Clearly, in samples containing a broad range of particle sizes, obtaining an analytical specimen in which the relative proportions of large and small particles are accurately represented is of importance.

Sampling statistics indicate that a specimen that will accurately and reproducibly represent the proportion of the larger particles in such a sample must be of a minimum weight or volume (Allen 1997). It is almost certain that none of the KE Basin test samples contained these amounts of solids. 


\section{RPP-RPT-30093, Rev. 0}

\section{QUALITY CONTROL}

\section{Replicate Measurements}

As previously noted, PSD measurements were performed on duplicate portions (specimens) withdrawn from each test sample. [Complete results for each of the PSD measurements are available on request.] The agreement of the duplicate Run 1 and Run 2 measurements for each sample was generally quite good. The level of agreement is demonstrated by the numerical data presented in Table 3.

\section{Standard Measurements}

Measurements of the PSDs of certified particle size standards were performed before sample measurements began and after they were completed. Measurements were completed on two certified particle size standards composed of monodisperse polystyrene microspheres. Standard measurement results are summarized in Table 5.

Table 5. Results of Measurements of Certified Standards.

\begin{tabular}{|c|c|c|c|}
\hline Identification & Туре & Certificd & Moasured \\
\hline $\begin{array}{l}\text { Duke Scientific } \\
4310 \mathrm{~A}-\text { Lot } 25974\end{array}$ & Polystyrene microspheres & $99.2 \pm 1.7 \mu \mathrm{m}$ & $103.9 \pm 7.5 \mu \mathrm{m}$ \\
\hline $\begin{array}{l}\text { Duke Scientific } \\
3150 \mathrm{~A}-\text { Lot } 27050\end{array}$ & Polystyrene nanospheres & $152 \pm 5 \mathrm{~nm}$ & $152 \pm 10 \mathrm{~nm}$ \\
\hline
\end{tabular}

The measured mean particle diameters for the standards were within $\pm 10 \%$ of the certified values.

\section{REFERENCES}

Allen, T., 1997, Particle Size Measurement: Volume 1-Powder Sampling and Particle Size Measurement, Fifth Edition, Powder Technology Series, Chapman and Hall, New York, New York.

ISO-13320-1, 1999, Particle Size Analysis - Laser Diffraction Methods - Part 1: General Principles, First Edition, International Organization for Standardization, Geneva, Switzerland.

NIST Special Publication 960-1, 2001, NIST Recommended Practice Guide: Particle Size Characterization, National Institute of Standards and Technology, U.S. Department of Commerce, Gaithersburg, Maryland. 